\title{
Marine Sedimentary Organic Matter: Delineation of Marine and Terrestrial Sources through Radiocarbon Dating; and the Role of Organic Sulfur in Early Petroleum Generation
}

by

\author{
Bryan C. Benitez-Nelson \\ B.S., Chemical Oceanography \\ University of Washington, 1992 \\ submitted in partial fulfillment of the requirements for the degree of \\ MASTER OF SCIENCE \\ at the \\ Massachusetts Institute of Technology \\ and the \\ Woods Hole Oceanographic Institution
}

May, 1996

C) 1996 Bryan C. Benitez-Nelson. All rights reserved.

The author hereby grants to MIT and WHOI permission to reproduce and to distribute copies of this thesis document in whole or in part.

Signature of Author

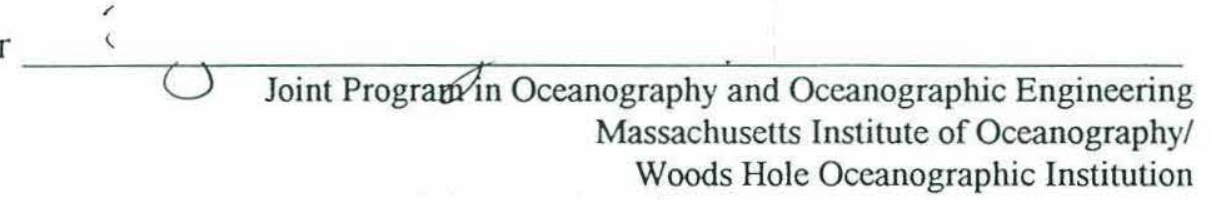

Certified by

Dr. Timothy I. Eglinton

Woods Hole Oceanographic Institution

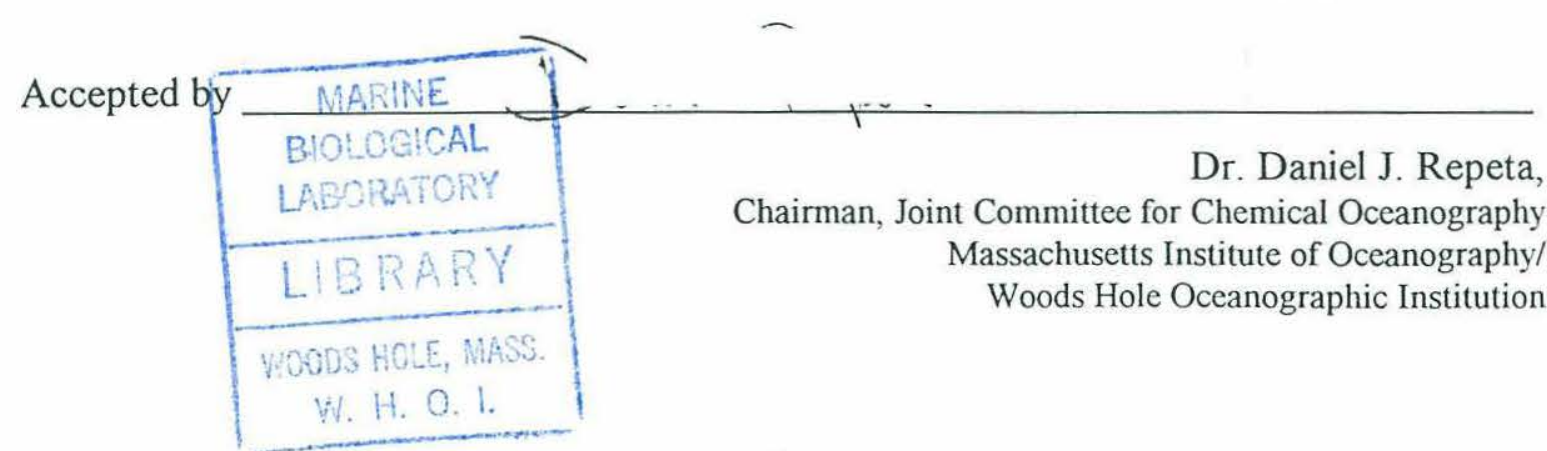




\section{Table of Contents}

Page 3. Introduction

Page 4. Chapter 1: Transformations in Organic Sulfur Speciation During Maturation of Monterey Shale: Constraints from Laboratory Experiments.

Page 28. Chapter 2: Chemical Mechanisms of Hydrocarbon and Non-hydrocarbon Gas Generation During Laboratory Hydrous-pyrolysis of Monterey and Smackover shales.

Page 51. Chapter 3: $A M S-{ }^{14} C$ Dating of Individual Compounds Isolated from Recent Marine Sediments. 


\section{Introduction}

This thesis details two years of research conducted with the guidance and support

of three advisors: Dr. J. K. Whelan, Dr. J. S. Seewald and Dr. T. I. Eglinton. Each of the three chapters represents a different, self-contained research project. All of the projects are related to the organic geochemistry of marine sediments, however, this is a fairly encompassing area of study. Chapters 1 and 2 stem from the same experimental study -the use of hydrous-pyrolysis to investigate mechanisms leading to the production of petroleum-related products during kerogen maturation. Chapter 3, on the other hand, utilizes a recently developed technique of isolating and $\mathrm{AMS}-{ }^{14} \mathrm{C}$ dating individual compounds from complex sedimentary organic mixtures.

The samples used in each investigation came from all over the world. The first two chapters utilize ancient marine sediment samples obtained from an outcrop in California (Chpts. 1 and 2) and from a well in Alabama (Chpt. 2). In contrast, recent marine sediment samples were obtained from the Arabian and Black Seas for the third chapter. Several preparative and analytical methods are common to all three studies. Nevertheless, each employ techniques totally unique from one another and from previous investigations. In Chapter 1, for example, X-ray absorption spectroscopy (XANES) is used to determine the speciation of organic sulfur present in kerogen, bitumen, and bulk sediment samples. While Chapter 3 represents the first study in which the ${ }^{14} \mathrm{C}$ ages of individual, known hydrocarbon biomarkers are determined after isolation by Preparative Capillary Gas Chromatography (PCGC). The insights gained by these investigations are discussed in detail in the following chapters. The common thread between the three chapters is that the source of organic matter, the rate at which it is delivered to marine sediments and the depositional environment, all set the stage for kerogen formation and eventual petroleum generation.

This work would have been nearly impossible, and definitely not as enjoyable without the help of my advisors, numerous research associates, fellow students and most of all, my wife Claudia. 


\title{
CHAPTER 1
}

\section{Transformations in Organic Sulfur Speciation During Maturation of Monterey shale: Constraints from Laboratory Experiments}

\author{
Bryan C. Nelson ${ }^{1}$, Timothy I. Eglinton ${ }^{1}$, Jeffrey S. Seewald ${ }^{1}$, \\ Appathurai Vairavamurthy ${ }^{2}$, Francis P. Miknis ${ }^{3}$
}

\footnotetext{
${ }^{1}$ Dept. of Marine Chemistry and Geochemistry, Woods Hole Oceanographic Institution, Woods Hole MA, 02543

${ }^{2}$ Dept. of Applied Science, Brookhaven National Laboratory, Upton, NY 11973, ${ }^{3}$ Western Research Institute, Laramie, WY 82071
}

This manuscript appeared in:

Geochemical Transformations of Sedimentary Sulfur (1995),

ACS Symposium Series 612,

Eds. M.A. Vairavamurthy and M.A.A.Schoonen, pps. $138-166$ 


\section{Introduction}

A series of hydrous pyrolysis experiments were conducted at temperatures ranging from 125 to $360^{\circ} \mathrm{C}$ at 350 bars pressure to examine variations in sulfur speciation during thermal maturation of Monterey shale. The total sediment, kerogen and bitumen from each experiment in addition to unheated representatives were analyzed via X-ray

absorption spectroscopy, pyrolysis-gas chromatography, ${ }^{13} \mathrm{C}$ NMR spectrometry, elemental analysis, thin-layer chromatography and reflected light microscopy.

Based on these measurements, it was possible to recognize three distinct temperature regimes, within which the type and amount of sulfur in the analyzed fractions underwent transformations: (i) between 150 and $225^{\circ} \mathrm{C}$, a significant proportion of kerogen-bound sulfur is lost probably due to the collapse of polysulfide bridges; (ii) between 225 and $275^{\circ} \mathrm{C}$, cleavage of -S-S- and -S-C- linkages within the kerogen is believed to occur, resulting in substantial production of polar sulfur-rich bitumen; (iii) above $275^{\circ} \mathrm{C}$ total bitumen yields as well as the proportion of bitumen sulfur decrease, while $\mathrm{C}-\mathrm{C}$ bond scission leads to increased yields of saturated and aromatic hydrocarbons.

The results from this study clearly and quantitatively establish a link between organically-bound sulfur, and more specifically, organic polysulfides, and the lowtemperature evolution of soluble petroleum-like products (bitumen) from sulfur-rich source rocks. There have been numerous investigations of the effects of heteroatoms (atoms other than carbon and hydrogen) in kerogen on the timing and thermal stress required for petroleum generation (Tissot, 1984; Tannenbaum and Aizenshtat, 1984; Lewan, 1985). In particular, the role of sulfur during low temperature petroleum generation has received a great deal of attention (Gransch and Posthuma, 1974; Orr, 1986; Lewan, 1985; Hunt et al., 1991; Baskin and Peters, 1992; Patience et al., 1992). These studies typically attributed early petroleum generation from sulfur-rich kerogens to the inherent weakness of sulfur-sulfur and sulfur-carbon bonds relative to carbon-carbon bonds (Lovering and Laidler, 1960). Studies of the role of sulfur in the sedimentary formation of kerogen (Sinninghe Damsté et al., 1989a,b; Orr and Sinninghe Damsté, 1990) suggest that sulfur linkages must be ubiquitous in sulfur-rich Type II-S kerogens 
$\left(\left(\mathrm{S}_{\text {org }} / \mathrm{C}\right)>0.04\right.$; (Orr, 1986)). These inferences implicating sulfur in maturation, however, are based largely on indirect and circumstantial evidence and the connection between the chemistry of sulfur-rich kerogens and the physical processes leading to petroleum generation remain unclear (Claxton et al., 1993).

The goal of this study was to gain further insight into the chemical changes involving sulfur during source rock maturation. In contrast to previous studies, emphasis was placed on direct assessment of the changes in sulfur species in the organic matter itself. A series of hydrous-pyrolysis experiments were conducted with sulfur-rich Monterey shale at temperatures ranging from 125 to $360^{\circ} \mathrm{C}$ to provide constraints on the speciation of sulfur in kerogen and generated products as a function of temperature. Although, temperatures higher than those found in natural settings are employed during hydrous-pyrolysis (in order to enhance reaction rates and allow organic transformations to be observed on a laboratory time scale), these experiments have proven an effective means to simulate the generation of hydrocarbons in the laboratory. Previous studies have shown that the pyrolysis-products are similar to products of geological maturation (Lewan, 1985; 1993). In addition, the processes leading to the generation and expulsion of oil during hydrous-pyrolysis experiments appear to be the same as those occurring in natural petroleum formation (Lewan, 1993).

An analytical scheme was designed to facilitate a mass-balance approach involving gases, bitumen, altered sediments and kerogens that allowed a detailed characterization of the fate of organic sulfur during thermal maturation. Analyses were conducted using X-ray absorption (XANES) spectroscopy, pyrolysis-gas chromatography (Py-GC), solid-state ${ }^{13} \mathrm{C}$ nuclear magnetic resonance (NMR) spectrometry, thin-layer chromatography with flame ionization detection (TLC-FID), elemental analyses and reflected light microscopy. This blend of analyses enabled the determination of gross and molecular-level transformations in sulfur speciation, as well as the manner by which they lead to the early conversion of kerogen to oil. 


\section{Methods}

\section{Sample Description and Preparation}

A thermally immature (Bituminite reflectance $=0.25 \%$ ) consolidated sediment sample from the Miocene Monterey Fm. (ML91-17) was obtained from an outcrop at Naples Beach, CA. The sample was removed from a $10 \mathrm{~cm}$ interval at the base of Unit 315 , approximately $9 \mathrm{~m}$ below the lowest phosphorite horizon (M.D. Lewan, personal communication). The sample comprised a lenticularly laminated claystone and visually appeared fresh (i.e. unweathered) and blocky. The surface of the sample was scraped prior to disc-mill pulverization to expose pristine material and remove possible contaminants.

Figure 1 illustrates the experimental scheme used in this study. Our primary goal was to examine the fate of kerogen-bound sulfur during artificial maturation. Consequently, after pulverization, the sediment sample was sequentially extracted by sonic disruption using $\mathrm{CH}_{3} \mathrm{OH} / \mathrm{CHCl}_{3}$ to remove indigenous bitumen. Sedimentary carbonate was removed from the sample by treating with $10 \% \mathrm{HCl}$ at $40^{\circ} \mathrm{C}$ for $2 \mathrm{hrs}$. For each experiment $1.0 \mathrm{~g}$ of solvent-extracted, carbonate-free sediment was used as the starting material except for the experiments at 225 and $275^{\circ} \mathrm{C}$, in which carbonate was not removed from the starting material. The sediment sample was loaded into a $20 \mathrm{~mL}$ ( $30.5 \times 0.9 \mathrm{~cm}$ i.d.) pipe-bomb, sealed and placed into a $62 \times 12.0 \mathrm{~cm}$ i.d. furnace. The air in the pipe-bomb was evacuated and the pipe-bomb was partially filled with argonpurged distilled water to ensure that the sediment was in contact with water during heating. Once at the experimental temperature, the pipe-bomb was filled completely with distilled water and pressurized to 350 bars so that only a single liquid phase was present (i.e., no head-space). Temperature was monitored $\left( \pm 2^{\circ} \mathrm{C}\right)$ with a thermocouple at each end of the pipe-bomb to ensure there were no thermal gradients. All experiments were $168 \mathrm{hrs}$ in duration.

During an experiment, fluid samples were withdrawn from the pipe-bomb through a $10 \mu \mathrm{m}$ filter into glass gas-tight syringes after approximately 24,72 and $168 \mathrm{hrs}$ and analyzed for the gas concentrations of dissolved gases. Pressure was maintained during the sampling process by pumping argon-purged distilled water into one end of the pipe- 
bomb while the fluid sample was removed from the other. The sampling process was performed rapidly (1 to $2 \mathrm{~min}$ ) to avoid dilution of the fluid samples with the freshly injected water. At the end of the experiment the pipe-bomb was cooled and all liquid contents were removed by sequentially pumping $30 \mathrm{~mL}$ of $\mathrm{CH}_{3} \mathrm{OH}$ and $\mathrm{CH}_{2} \mathrm{Cl}_{2}$ through the pipe-bomb. Subsequently, the pipe-bomb was opened and the solid residue was removed by rinsing with additional solvent. The combined $\mathrm{CH}_{3} \mathrm{OH} / \mathrm{CH}_{2} \mathrm{Cl}_{2}$ extract was centrifuged and the liquid products decanted. After drying at $40^{\circ} \mathrm{C}$ in air, the solid residue was sequentially extracted by sonic disruption in $\mathrm{CH}_{3} \mathrm{OH} / \mathrm{CH}_{2} \mathrm{Cl}_{2}$ to ensure complete recovery of the generated bitumen. This extract was combined with the pipebomb rinses, back-extracted with distilled $\mathrm{H}_{2} \mathrm{O}$, dried over anhydrous $\mathrm{Na}_{2} \mathrm{SO}_{4}$ and filtered $(0.45 \mu \mathrm{m})$ to remove residual suspended material yielding the generated bitumen. A split

of the altered sediment ( $\sim 350 \mathrm{mg}$ ) was demineralized through $\mathrm{HCl}$ and $\mathrm{HF}$ acid digestions at room temperature (Eglinton and Douglas, 1988) to obtain a kerogen isolate. An aliquot $(\sim 50 \mathrm{mg})$ of the kerogen isolate was treated with $\mathrm{CrCl}_{2}$ and concentrated $\mathrm{HCl}$ to remove inorganic sulfur (Canfield et al., 1986; Acholla and Orr, 1993).

\section{Gas Analysis}

Dissolved $\mathrm{CO}_{2}$ and light $\left(\mathrm{C}_{1}-\mathrm{C}_{4}\right)$ hydrocarbons in the fluid samples from all experiments were analyzed using a purge and trap apparatus interfaced to a gas chromatograph. Dissolved $\mathrm{H}_{2} \mathrm{~S}$ concentrations were monitored to obtain an estimate of the amount of sulfur, both inorganic and organic, removed from the system as $\mathrm{H}_{2} \mathrm{~S}$ during sediment maturation. The absolute concentration of dissolved $\mathrm{H}_{2} \mathrm{~S}$ was determined gravimetrically by precipitation as $\mathrm{Ag}_{2} \mathrm{~S}$ in a $3 \mathrm{wt} \% \mathrm{AgNO}_{3}$ solution.

\section{Elemental Analysis}

Elemental analyses were performed at the termination of each experiment in order to monitor fluctuations in the distribution of sulfur and carbon among the various fractions resulting from maturation of the Monterey shale. Weight percent $\mathrm{C}, \mathrm{H}, \mathrm{N}$ and $\mathrm{S}$ were determined for all fractions including those obtained from unheated, solvent- 
extracted Monterey shale. Elemental analyses were conducted using a Leco 932 elemental analyzer.

\section{X-Ray Absorption Spectroscopy (XANES)}

X-ray Absorption Near Edge Structure (XANES) Spectroscopy was performed at the National Synchrotron Light Source at Brookhaven National Laboratory on Beamline X-19A (Eglinton et al., 1994; Vairavamurthy et al., 1994). XANES was conducted on the unheated and altered sediments, bitumen, and $\mathrm{CrCl}_{2}$-treated kerogens to observe thermally-induced changes in sulfur speciation within and between the various fractions. Solid samples were prepared as boric acid pellets, whereas liquid samples were taken to near dryness and adsorbed onto pre-combusted GF/F filters under a $\mathrm{N}_{2}$ atmosphere, heatsealed in air-tight pouches and kept frozen prior to analysis. Solid and liquid samples were analyzed while mounted in a He-purged sample chamber. XANES spectra of all fractions were acquired from 2465 to $2900 \mathrm{eV}$ using a Lytle fluorescence detector. A monochromator step function was chosen to provide a resolution of $0.5 \mathrm{eV}$ at the nearedge region.

Quantitative deconvolution of the XANES spectra was accomplished using a computer algorithm developed by Waldo et al. (1991). After corrections to account for background and self-absorption, the proportions of different sulfur species were calculated by fitting the normalized spectra (least-squares procedure) with up to six reference-compound spectra. For this study, $\mathrm{FeS}_{2}$, elemental sulfur, cysteic acid, sodium sulfate, benzyl sulfide, dibenzyl trisulfide, dibenzothiophene and dibenzylsulfoxide were used as reference compounds. The accuracy of these results are estimated to be $\pm 10 \%$. Optimal curve-fitting of the XANES spectra from analyses of altered sediments and kerogens prior to $\mathrm{CrCl}_{2}$ treatment was difficult due to the presence of inorganic sulfur compounds (pyrite). Consequently, sulfur speciation determinations are reported only for the bitumen and $\mathrm{CrCl}_{2}$-treated kerogen. 


\section{Analytical Pyrolysis (Py-GC)}

Analytical pyrolysis was conducted to determine the relative distribution of volatile thiophenic and hydrocarbon pyrolysis-products from the kerogen and pyrite-free kerogen samples from the unheated and matured Monterey Shale. Pyrolysis-Gas Chromatography was performed using a FOM-3LX Curie-point pyrolysis unit (controlled by a Horizon RF generator) interfaced to a Hewlett-Packard 5890 Series II GC (Eglinton et al., 1994). Kerogen samples were loaded onto Fe/Ni wires with a Curie temperature of $610^{\circ} \mathrm{C}$. Samples were pyrolyzed for $5 \mathrm{~s}$ and the pyrolysis interface temperature was set at $200^{\circ} \mathrm{C}$. Helium was used as the carrier gas. Separation of the pyrolysis products was achieved on a Restek $R_{\mathrm{TX}-1}$ column ( $50 \mathrm{~m}$ x $0.32 \mathrm{~mm}$ i.d.; film thickness $0.5 \mu \mathrm{m}$ ) using a temperature program from $30^{\circ} \mathrm{C}\left(5 \mathrm{~min}\right.$ initial time) to $320^{\circ} \mathrm{C}$ ( $15 \mathrm{~min}$ final time) at a rate of $3^{\circ} \mathrm{C} \mathrm{min}{ }^{-1}$. The GC effluent was split and simultaneously monitored by a flame ionization detector (FID) and a sulfur-selective flame photometric detector (FPD). Flash pyrolysis of the kerogen and pyrite-free kerogen fractions yielded near-identical results, indicating that the $\mathrm{CrCl}_{2}$-treatment did not affect the relative distribution of $\mathrm{GC}$-amenable (i.e. volatile) products analyzed.

\section{Nuclear Magnetic Resonance (NMR) Spectrometry}

Solid-state ${ }^{13} \mathrm{C}$ NMR spectrometry was used to determine changes in the carbon structure of the altered sediments, kerogens and $\mathrm{CrCl}_{2}$-treated kerogens that occurred as a result of thermal maturation. Solid-state ${ }^{13} \mathrm{C}$ NMR measurements were made using the technique of cross polarization (CP) with magic-angle spinning (MAS) at a carbon frequency of $25 \mathrm{MHz}$ using a ceramic probe and a $7.5 \mathrm{~mm}$ o.d. zirconia pencil rotor. As a consequence of the small amounts of sample material available for the NMR measurements ( $\sim 20 \mathrm{mg}$ for the kerogens and $\sim 100 \mathrm{mg}$ for the altered sediments), data were collected over periods of 15 to $18 \mathrm{hrs}(54,000$ and 64,800 transients). A pulse delay of $1 \mathrm{~s}$, a contact time of $1 \mathrm{~ms}$, a $5.0 \mu$ s pulse width and a sweep width of $16 \mathrm{kHz}$ were used to acquire data. Sample spinning speeds were $\sim 4.5 \mathrm{kHz}$. A $50 \mathrm{~Hz}$ exponential multiplier was applied to the free induction decay of each ${ }^{13} \mathrm{C}$ spectrum before integration. 
The NMR spectra were integrated between 90 and 260 ppm for the "aromatic" region and -40 to $90 \mathrm{ppm}$ for the "aliphatic" region. The spinning rates were sufficiently high so that contributions to the aliphatic integrals from high field aromatic carbon spinning sidebands were negligible and were not included in the aliphatic carbon integrals. The carbon aromaticity values can contain contributions from carbonyl $(\sim 210$ ppm) and carboxyl carbons ( 180 ppm), if present.

\section{Bituminite Reflectance}

Microscopic examination of the initial (unheated) sediment sample revealed that the majority of organic matter was comprised of an amorphous groundmass termed "bituminite" (Teichmuller, 1986), with only trace amounts of recognizable vitrinite. Bituminite, which is believed to derive from degraded algal and bacterial matter, is thus considered to be a major kerogen constituent. For this reason, and because vitrinite is so scarce, direct measurements of reflectance were made on this bituminite in order to assess the extent of thermal alteration.

\section{Thin-layer Chromatography}

Quantification of the saturated, aromatic and polar compound classes in the bitumen was performed by thin-layer chromatography with flame ionization detection (TLC-FID) according to the methods of Karlsen and Larter (1991) using an Iatroscan TH10 Mark III instrument. $1.5-2.0 \mu \mathrm{L}$ of each sample (dissolved in $\mathrm{CH}_{2} \mathrm{Cl}_{2}$ ) was applied to silica rods which were sequentially developed in $\mathrm{C}_{6} \mathrm{H}_{14}(10 \mathrm{~cm}), \mathrm{C}_{7} \mathrm{H}_{8}(5 \mathrm{~cm})$ and a 95:5 solution of $\mathrm{CH}_{2} \mathrm{Cl}_{2}: \mathrm{CH}_{3} \mathrm{OH}(2 \mathrm{~cm})$. A standard mixture comprised of $n$-eicosane, dibenzothiophene and 2,6-dimethoxyphenol was used for calibration of response factors for aliphatic, aromatic and polar compounds, respectively. 


\section{Results}

\section{Gaseous Phases}

Dissolved $\mathrm{H}_{2} \mathrm{~S}$ concentrations were measured during five of the hydrous-pyrolysis experiments (Table 1). During these experiments the concentration of dissolved $\mathrm{H}_{2} \mathrm{~S}$ was likely controlled by the solubility of iron sulfides such as pyrite and/or pyrrhotite owing to the rapid precipitation/dissolution kinetics for these phases under hydrothermal conditions (Seewald and Seyfried, 1990). Pyrite was abundant in the unheated sediment and persisted along with newly formed pyrrhotite in the thermally altered sediments. At temperatures below $225^{\circ} \mathrm{C}$ dissolved $\mathrm{H}_{2} \mathrm{~S}$ concentrations were too low to be determined gravimetrically, but $\mathrm{H}_{2} \mathrm{~S}$ was detectable by odor in all experiments. Sources of dissolved $\mathrm{H}_{2} \mathrm{~S}$ during the experiments include diagenetic pyrite and organic sulfur. It is not possible to directly determine the relative contributions from these two sources based on dissolved concentrations alone. However, at 350 and $360^{\circ} \mathrm{C} 12.7$ and $18.8 \mathrm{mg} \mathrm{H}_{2} \mathrm{~S} / \mathrm{g}$ rock was released to solution respectively. These amounts exceed the amount of sulfur present as diagenetic pyrite in the initial sediment ( $10.5 \mathrm{mg} / \mathrm{g}$ sediment), and thereby provide direct evidence for the release of organically bound sulfur to solution. Because dissolved sulfide is cycled through the fluid into sulfide minerals, the calculated contributions of organic sulfur to solution represent an absolute minimum.

\section{Generated Bitumen}

The total bitumen extract, saturated, aromatic and polar compound yields from each experiment and the indigeneous material removed from the sample prior to heating, are listed in Table 1 and illustrated in Figure 2. The initial bitumen content of the unheated sediment was approximately $11 \mathrm{mg} / \mathrm{g}$ rock. We estimate an extraction efficiency of $>70 \%$ in removing this bitumen from the starting material, and hence any contribution from indigenous bitumen to extractable yields after the experiments is likely to be minor. In all cases, polar compounds comprised the majority of each bitumen fraction and, as a result, the total extract largely mirrored polar compound yields. The yield of polars increased with temperature to a maximum in the $275^{\circ} \mathrm{C}$ experiment $(62.0$ $\mathrm{mg} / \mathrm{g}$ rock), above which concentrations decreased. The yield of saturate and aromatic 
compounds were similar to each other with maxima in the experiments at temperatures above $275^{\circ} \mathrm{C}$.

The results of the elemental analyses $(\mathrm{C}, \mathrm{H}, \mathrm{N}$ and $\mathrm{S})$ of the bitumen are listed in Table 2. Above $250^{\circ} \mathrm{C}$ the atomic ratio of hydrogen to carbon $(\mathrm{H} / \mathrm{C})$ decreased while the atomic ratio of nitrogen to carbon (N/C) remained relatively constant. Above $150^{\circ} \mathrm{C}$ the bitumen initially exhibited an increase in the sulfur to carbon (S/C) ratio with temperature which reached a maximum at $250^{\circ} \mathrm{C}$ followed by a decrease (Fig. 3).

Normalized (K-edge) XANES spectra of the bitumen are illustrated in Figure 4. Reduced sulfur species (sulfides) are represented by peaks that occur towards the left side of each spectra, whereas peaks for more oxidized species (sulfoxides) are found at higher energies. Fitting of the XANES spectra reveal that organic sulfides and polysulfides were the primary sulfur forms contained in the bitumen and typically accounted for over $50 \%$ of the sulfur present (Fig. 5). The remaining sulfur was in the form of thiophenes and sulfoxides. Thiophenes and sulfoxides exhibited relatively little change with temperature, while organic sulfides and polysulfides increased significantly from $3 \%$ to a maximum of $8 \%$ of the bitumen at $275^{\circ} \mathrm{C}$. Above this temperature the weight percent of sulfides and polysulfides in the bitumen decreased.

\section{Solid Phases}

In the altered sediments, weight percent organic carbon, nitrogen and sulfur as well as the $\mathrm{S} / \mathrm{C}$ atomic ratio, decreased with increasing temperature (Table 2). In the kerogens the $\mathrm{H} / \mathrm{C}$ atomic ratio decreased at higher temperatures $\left(>250^{\circ} \mathrm{C}\right)$ while the N/C atomic ratio remained fairly constant. In contrast to the bitumen, the $\mathrm{S} / \mathrm{C}$ ratio of the kerogen initially decreased with increasing temperature (Fig. 3). This decrease was first apparent in kerogens from experiments above $175^{\circ} \mathrm{C}$, with the $\mathrm{S} / \mathrm{C}$ ratio changing from $\sim 0.05$ to $<0.02$ in kerogen from experiments above $300^{\circ} \mathrm{C}$. Between 325 and $360^{\circ} \mathrm{C}$, the S/C ratio remained constant.

Bituminite reflectance measurements of the altered sediments are listed in Table 3 and illustrated in Figure 6. The reflectance value of the bituminite present in the altered sediment were low $(0.25 \%)$, relative to vitrinite of the same sample $(0.39 \%)$, due to the 
hydrogen-rich nature of the former (Robert, 1988; Lo, 1993). Maturation of the altered sediments, however, was clearly indicated by increased reflectance with temperature, especially above $275^{\circ} \mathrm{C}$ (Fig. 6), and $\mathrm{R}_{\mathrm{o}}$ reached a maximum of $0.95 \%$ in the $360^{\circ} \mathrm{C}$ altered sediment samples.

Results from CP/MAS ${ }^{13} \mathrm{C}$ NMR measurements of the altered sediments and kerogens are listed in Table 3 and illustrated in Figure $6 .{ }^{13} \mathrm{C}$ NMR spectra of the unheated and artificially matured kerogens are shown in Figure 7. The major band of the right portion of each spectrum $(0-60 \mathrm{ppm})$ represents carbon in aliphatic structures including structures with sulfide bonds. The major band to the left of each spectrum represents carbon in aromatic (90-160 ppm) structures (including thiophenes), and in any carboxylate $(\sim 180 \mathrm{ppm})$ and carbonyl $(\sim 210 \mathrm{ppm})$ structures that may be present. Very little variation was observed in the ${ }^{13} \mathrm{C}$ NMR results from the altered sediment, kerogen and $\mathrm{CrCl}_{2}$-treated kerogen from the same experiments (Table 3, Fig. 6). Comparison of the ${ }^{13} \mathrm{C}$ NMR spectra from each experiment, however, clearly show a preferential loss of aliphatic carbons relative to aromatic carbons with increasing temperature (Fig. 7). Examination of Figure 6 reveals an exponential relationship between temperature and aromaticity with a major steepening in the curve above $275^{\circ} \mathrm{C}$.

Partial FID and FPD chromatograms from flash pyrolysis $\left(610^{\circ} \mathrm{C}\right)$ of the unheated, 250, 300 and $360^{\circ} \mathrm{C}$ kerogens are shown in Figure 8. FPD peak assignments were made by comparison of relative retention times to earlier studies (Eglinton et al., 1992; 1994), and are listed in Table 4 with the inferred carbon skeletons of the bound precursors (Sinninghe Damsté et al., 1989a). The major peaks in the FID chromatograms are due to $n$-alkanes and $n$-alkenes, alkylbenzenes and thiophenes (Fig. 8). The Py-GC results indicate a preferential loss of aromatic and especially thiophenic compounds relative to $n$-hydrocarbons with increasing temperature. The generation potential for $n$ alkanes and $n$-alkenes remains high until approximately $300^{\circ} \mathrm{C}$ suggesting that $\mathrm{C}$-C cracking has not occurred to a significant extent below this temperature. Above $325^{\circ} \mathrm{C}$ essentially only gaseous products $\left(\mathrm{CH}_{4}, \mathrm{C}_{2} \mathrm{H}_{6}, \mathrm{C}_{2} \mathrm{H}_{4}, \mathrm{H}_{2} \mathrm{~S}\right)$ were detected in the flash pyrolyzates. 
Estimates of the relative abundance of volatile thiophenic versus hydrocarbon pyrolysis products were made from the ratio of FID peak areas for 2-methylthiophene (2MT) to the sum of toluene (Tol) and $n-\mathrm{C}_{7}$ alkene $\left(\mathrm{C}_{7} \mathrm{H}_{14}\right)$ (Fig. 9). The $2 \mathrm{MT} /\left(\mathrm{Tol}+\mathrm{C}_{7} \mathrm{H}_{14}\right)$ ratio decreased slightly with increased temperature up to $250^{\circ} \mathrm{C}$ (Fig. 9). At temperatures greater than $250^{\circ} \mathrm{C}$, the ratio decreased sharply and approached zero above $325^{\circ} \mathrm{C}$. Although kerogens from the experiments below $250^{\circ} \mathrm{C}$ exhibited very little change in the $2 \mathrm{MT} /\left(\mathrm{Tol}+\mathrm{C}_{7} \mathrm{H}_{14}\right)$ ratio, the $\mathrm{S} / \mathrm{C}$ ratio decreased significantly (from 0.051 to 0.032) relative to the unheated sample (Fig. 9). Conversely, a sharper decrease in the $2 \mathrm{MT} /\left(\mathrm{Tol}+\mathrm{C}_{7} \mathrm{H}_{14}\right)$ ratio above $250^{\circ} \mathrm{C}$ coincided with only a moderate change in the S/C ratio (Fig. 9).

The predominant sulfur-containing pyrolysis products in all FPD chromatograms were $\mathrm{H}_{2} \mathrm{~S}$ and low molecular weight thiophenes (Fig. 8). $\mathrm{H}_{2} \mathrm{~S}$ was likely derived from the thermal decomposition of pyrite, present in the kerogen, as well as from the cleavage of organically-bound thiols, aliphatic sulfides (thiolanes, thianes) or sulfide bridges (Eglinton et al., 1994). Volatile thiophenic pyrolysis products were observed in the kerogens from all the experimental temperatures except for the 350 and $360^{\circ} \mathrm{C}$ experiments (Fig. 8). At temperatures $<300^{\circ} \mathrm{C}$ no marked changes in the internal distribution of thiophenic products were observed. At $300^{\circ} \mathrm{C}$ and above, however, the relative contribution of 2-methylthiophene, 2,5-dimethylthiophene, 2-ethyl-5methylthiophene and 2-methyl-5-propylthiophene decreased more dramatically than other thiophenic products (Fig. 8).

Normalized (K-edge) XANES spectra of the $\mathrm{CrCl}_{2}$-treated kerogens are illustrated in Figure 4. With increased temperature a sharpening in the shape of the major peak occurred, as well as a slight $(\sim 1 \mathrm{eV})$ shift towards higher energy. This shift is detectable at $175^{\circ} \mathrm{C}$ and clearly evident by $225^{\circ} \mathrm{C}$ (Fig. 4). The percentages of the major forms of sulfur (normalized to\%S) in the kerogen determined by fitting of the XANES spectra are illustrated in Figure 5. The primary sulfur forms present in the unheated kerogen were organic sulfides and polysulfides. Together these two species account for $\sim 50 \%$ of the sulfur while, thiophenes and sulfoxides comprised the majority of the remaining sulfur. Systematic changes in sulfur speciation as a function of temperature are clearly evident 
(Fig. 5). Similar to the bitumen, thiophenes and sulfoxides present in the kerogens remained relatively constant with increased temperature. In contrast, organic sulfides and polysulfides decreased with temperature from 4.7 to $0.4 \%$ in the unheated and $360^{\circ} \mathrm{C}$ pyrite-free kerogens, respectively (Fig. 5) with two marked decreases occurring above $175^{\circ} \mathrm{C}$ and $250^{\circ} \mathrm{C}$. Above $250^{\circ} \mathrm{C}$ the relative proportion of thiophenic sulfur exceeded that present as organic sulfides.

\section{Discussion}

\section{Compositional Characteristics of Unheated Monterey Shale Kerogen}

The values obtained from bituminite reflectance $\left(\% R_{0}=0.25\right)$, solid-state CP/MAS ${ }^{13} \mathrm{C}$ NMR spectroscopy (aromaticity $\left.=0.34\right)$ and Rock-Eval $\left(\mathrm{T}_{\max }=386^{\circ} \mathrm{C}\right)$ measurements all indicate that the unheated Monterey kerogen was relatively immature. In addition, with an atomic $\mathrm{S}_{\text {org. }} / \mathrm{C}$ ratio of 0.051 the sulfur-rich Monterey kerogen (Wt.\%S = 9.45) can be classified as "Type II-S" (Orr, 1986).

The homologous series of $n$-alkanes and $n$-alkenes present in the partial Py-GCFID chromatogram of the unheated Monterey kerogen sample is typical of a wide range of oil-prone, immature kerogens (Eglinton et al., 1990a). The distinguishing feature of Monterey shale and other sulfur-rich kerogens, however, is the high relative abundance of thiophenes released during pyrolysis (Eglinton et al., 1990a; 1992). The thiophenic pyrolysis products detected by FPD can provide direct information regarding the chemical nature of macromolecularly bound sulfur (Sinninghe Damsté, 1989a; Eglinton et al., 1992). When pyrolysis is conducted using wires with a Curie temperature of $610^{\circ} \mathrm{C}, \mathrm{S}-\mathrm{S}$, $\mathrm{C}-\mathrm{S}$ and $\mathrm{C}-\mathrm{C}$ bonds are cleaved and sulfur-bound or sulfur-containing moieties present in the kerogen will generate a variety of products through $\beta$-cleavage, $\gamma$-hydrogen rearrangement and by $\gamma$-cleavage (Sinninghe Damsté, 1989a). Based on the substitution patterns of the thiophenes and benzothiophenes yielded upon pyrolysis, carbon skeletons of different sulfur-containing moieties originally present in the kerogen can be distinguished (Sinninghe Damsté, 1989a). Similar to previous studies of Monterey shale and other immature Type II-S kerogens (Eglinton et al., 1992; 1994), a significant 
proportion of the sulfur-containing pyrolysis products from the unheated Monterey kerogen are derived from isoprenoid and/or steroidal carbon skeletons (Fig. 8, Table 4).

Complementary information regarding the sulfur-containing structures present in the kerogen can be obtained through X-ray absorption (XANES) spectroscopy. In addition, XANES spectroscopy allows all forms of sulfur present in the sample to be "seen", whereas pyrolysis only liberates volatile species. In contrast to the flash-pyrolysis approach, XANES spectroscopy reveals the electronic environment of the sulfur atom and does not provide information on the configuration of carbon atoms, other than those in close proximity to sulfur. The XANES data reveal that organic sulfides and polysulfides, thiophenes and sulfoxides comprise 4.7, 2.3 and 0.9 weight percent of the unheated, $\mathrm{CrCl}_{2}$-treated kerogen, respectively (Fig. 5). Thus, sulfides and polysulfides account for $>50 \%$ of the total sulfur in the unheated kerogen. The low percentage of sulfoxides indicates that oxidation of sulfur during sample manipulation was minor. K-edge XANES spectra do not allow for the discrimination between cyclic (thiolanes, thianes) and acyclic sulfides. By assuming, however, that the relative proportion of cyclic and acyclic sulfides is approximately equivalent, the ratio of thiophenes (a cyclic form of sulfur) to total sulfides can be used as an estimate of the extent of intra-versus intermolecular S-bonding (Eglinton et al., 1994). Based on this premise, XANES spectroscopic analysis of the unheated Monterey kerogen would indicate that sulfur crosslinking is extensive and that there are abundant, potentially weak S-linkages where thermally-induced cleavage might occur.

\section{Transformations During Laboratory Maturation}

In order to constrain sources and sinks of sulfur as a function of temperature, we have calculated the fraction of the total sedimentary sulfur present in three major phases: kerogen, bitumen and total inorganic sulfur (Fig. 10). The latter pool is calculated by difference assuming a closed system and an initial total sedimentary S content (3.86\%; Table 2) and is predominantly composed of $\mathrm{H}_{2} \mathrm{~S}$, pyrite and pyrrhotite. For comparison, the distribution of carbon associated with gaseous species $\left(\mathrm{C}_{1}-\mathrm{C}_{3}\right.$ hydrocarbons, $\left.\mathrm{CO}_{2}\right)$, bitumen and kerogen are also shown in Figure 10. Plotting the data in this way shows 
several interesting trends which reveal systematic transformations in the concentrations and speciation of sulfur in each of the phases analyzed. These transformations also reveal the interplay between each phase during the maturation process.

In the unheated sediment the dominant portion (ca. 75\%) of the sedimentary S is associated with kerogen, pyritic sulfur representing the remainder. Essentially no sulfur is associated with indigenous bitumen since extractable material was removed from the immature starting material (it is also assumed there is initially a negligible amount of adsorbed $\mathrm{H}_{2} \mathrm{~S}$ ). This condition prevails at temperatures up to $150^{\circ} \mathrm{C}$, above which the proportion of kerogen-bound sulfur decreases markedly from 3.0 to $1.8 \%$ at $225^{\circ} \mathrm{C}$. Only a minor increase in solvent extractable sulfur was observed over this temperature interval, and accordingly the loss of kerogen sulfur is balanced by the production of inorganic sulfur. Above $250^{\circ} \mathrm{C}$ a further decrease in kerogen sulfur is apparent, and this is accompanied by an increase in bitumen sulfur, which peaked at $275^{\circ} \mathrm{C}$. This maximum also corresponds with the temperature of maximum bitumen generation (Fig. 2) and, in particular, polar compound evolution. Above $275^{\circ} \mathrm{C}, \mathrm{S}$ in both bitumen and kerogen decreases resulting in an increase in inorganic sulfur. The total decrease of kerogen sulfur from the unheated sample to the $360^{\circ} \mathrm{C}$ residue was approximately a factor of 4 (i.e. 2.8 to $0.7 \%$ ).

Based on this mass balance information, and the compositional transformations observed, we can construct an overview of the likely fate of organically-bound sulfur during laboratory maturation of the Monterey shale. The earliest transformations occur at very low $\left(\leq 175^{\circ} \mathrm{C}\right)$ temperatures (in terms of artificial maturation experiments). This change has not been studied in detail previously, since it occurs well below the temperature at which the primary generation of hydrocarbon-like products takes place during laboratory heating experiments (Lewan, 1985; Baskin and Peters, 1992). The decrease in kerogen sulfur implies that a substantial degree of internal rearrangement takes place within the kerogen macromolecular network, even under mild thermal stress. These rearrangements do not result in significant amounts of soluble (petroleum-like) products, but $\mathrm{H}_{2} \mathrm{~S}$ is generated. We postulate that the $\mathrm{H}_{2} \mathrm{~S}$ is primarily an elimination product from polysulfide bridges within the kerogen. Cleavage of bridges containing 2 or 
more S-atoms would yield $\mathrm{H}_{2} \mathrm{~S}$ and the bridge may subsequently reform, the result being negligible release of soluble organic products.

Alternatively, sulfide bridges could be broken, yielding $\mathrm{H}_{2} \mathrm{~S}$, but insufficient bridges are broken to release soluble, carbon-containing moieties from the kerogen. Whatever the case, the net result is a loss of sulfur from the kerogen with no concomitant carbon loss. Based on the XANES analyses it is clear that the sulfur is removed from the kerogen during these "low temperature" experiments primarily as sulfides or polysulfides (Fig. 5). This is also evident from the pyrolysis-based thiophene ratios, which show no decrease over this temperature interval (Fig. 9). Both these observations are consistent with (poly)sulfide bridges as the reactive sulfur species. Unfortunately K-edge XANES does not allow unequivocal distinction of mono-sulfide from polysulfide species so this inference cannot be verified quantitatively. Nevertheless, qualitative support for the lowtemperature reactivity of polysulfides is apparent in the normalized (K-edge) XANES spectra of the kerogens (Fig. 4). Above $175^{\circ} \mathrm{C}$ there is a $\sim 1 \mathrm{eV}$ shift in the maximum for the lowest energy peak towards higher energy. Because organic polysulfides exhibit slightly lower K-edge energies than corresponding mono-sulfides this shift suggests preferential removal of polysulfides over mono-sulfides at lower temperatures.

Between $225^{\circ} \mathrm{C}$ and $300^{\circ} \mathrm{C}$ a significant proportion of the kerogen is converted to polar-rich bitumen (Fig. 2). Polar compounds (resins and asphaltenes) are considered to be large, soluble macromolecules with a strong genetic link to kerogen (i.e. soluble kerogen moieties) (Sinninghe Damsté and de Leeuw, 1990). The bitumen generated at $275^{\circ} \mathrm{C}$ is enriched in sulfur compared to both lower and higher temperature soluble products and, based on the XANES data, is dominated by (poly)sulfide sulfur. We interpret these data to imply that the bitumen derived from these experiments is predominantly the result of cleavage of sulfide links in the kerogen, liberating lower molecular weight (and therefore soluble) kerogen sub-fragments which retain abundant sulfide linkages within their infrastructure. Since sulfur in the newly generated bitumen cannot account for all of the sulfur lost from the kerogen, continued $\mathrm{H}_{2} \mathrm{~S}$ formation at these temperatures is also implied. 
At higher temperatures $\left(>300^{\circ} \mathrm{C}\right)$ bitumen formation via cleavage of sulfur links gives way to hydrocarbon generation through $\mathrm{C}-\mathrm{C}$ bond scission. Presumably hydrocarbons are generated from both the kerogen and bitumen. These conditions result in soluble products which contain increasing proportions of aliphatic and aromatic hydrocarbons (including aromatized sulfur compounds) with maximum yields observed at $325^{\circ} \mathrm{C}$ for the former and $360^{\circ} \mathrm{C}$ for the latter (Fig. 2). The temperature regime between 275 and $360^{\circ} \mathrm{C}$ is also where the most marked changes in the carbon structure of the kerogen occurred, as indicated by bituminite reflectance and NMR spectrometry, which suggest increasing aromaticity. Also of note is the dramatic reduction in abundance of (poly)sulfide sulfur in the kerogen (Fig. 5). In terms of relative proportions, thiophenic sulfur exceeds that of sulfidic sulfur above $250^{\circ} \mathrm{C}$ in the kerogen.

The distribution of carbon in the various pools resulting from the artificial maturation of Monterey shale (Fig. 10) is consistent with the above interpretation of the fate of organic sulfur during maturation. It is expected that the relative concentration of organic carbon associated with the kerogen $\mathrm{C}$ would decrease as bitumen and gaseous products are generated. Although this held true for experiments at $250^{\circ} \mathrm{C}$ and above, an increase in kerogen $\mathrm{C}$ over that of the unheated sample was observed at $125-175^{\circ} \mathrm{C}$. This was likely due to the low-temperature dissolution of non-carbon containing minerals originally present in the Monterey shale (e.g. refractory phosphates). Overall, kerogen C decreased from approximately 21 to $15 \%$ in the unheated and $360^{\circ} \mathrm{C}$ samples, respectively (Fig. 10), while gaseous organic carbon, in particular $\mathrm{CH}_{4}$ and $\mathrm{CO}_{2}$, increased with increasing temperature. Very little $(<1 \%)$ organic carbon was associated with the bitumen $\mathrm{C}$ until $250^{\circ} \mathrm{C}$, with a maximum in bitumen $\mathrm{C}$ at $275^{\circ} \mathrm{C}$ (Fig. 10). This is consistent with the thermally induced cleavage of sulfide links in the kerogen freeing soluble, carbon-containing structures to the bitumen. At higher temperatures $\mathrm{C}-\mathrm{C}$ bonds in these soluble structures are likely broken leading to hydrocarbon and ultimately gas generation.

The generation of petroleum-like products as a function of temperature during the experiments presented here is consistent with previous experimental studies on sulfurrich kerogens. The formation of expelled oil has been modeled as a two step process 
involving the decomposition of generated bitumen to form a compositionally distinct oil phase (Lewan, 1985; Baskin and Peters, 1992). Although we cannot distinguish between generated bitumen and expelled oil in our experiments, compositional variations in the total extractable bitumen support such a model. Bitumen, as defined by Lewan (1993), is rich in polar compounds relative to expelled oil, which contains substantially greater proportions of saturate and aromatic hydrocarbons. During our experiments we observed a clear offset between peak generation of polar compounds at $\left(275^{\circ} \mathrm{C}\right)$ and aliphatic and aromatic compounds $\left(325-360^{\circ} \mathrm{C}\right)$, consistent with early bitumen generation which in turn decomposes to produce a more oil-like substance. These temperatures for peak bitumen and inferred oil formation are significantly lower than those from hydrous-pyrolysis (72 hrs) of the relatively sulfur-poor Woodford shale $\left(330\right.$ and $350^{\circ} \mathrm{C}$, respectively) and the Phosphoria shale $\left(300\right.$ and $\left.350^{\circ} \mathrm{C}\right)$, characterized by an intermediate organic sulfur content (Lewan, 1985). Baskin and Peters (1992) conducted hydrous-pyrolysis experiments for $72 \mathrm{hrs}$ utilizing the Monterey shale and observed peak bitumen and oil formation at 280 and $330^{\circ} \mathrm{C}$, respectively. These temperatures are almost identical to those observed during this study, the difference in heating time notwithstanding. Taken collectively, the experimental results provide strong evidence for the early generation of bitumen and oil from sulfur-rich kerogens, relative to sulfur-poor kerogen, owing to the preferential cleavage of weak sulfur linkages.

Interpreting the above results within the context of geological maturation of sulfur-rich source rocks such as the Monterey Fm., we can make several inferences. The first concerns the general phenomenon of low temperature petroleum generation. We have observed relatively low temperatures (experimentally-speaking) for maximum bitumen generation $\left(275^{\circ} \mathrm{C}\right)$ during our experiments. This maximum reflects the liberation (or formation) of sulfur-rich high molecular weight heterocompounds (polar compounds) which clearly indicates the transfer of a significant proportion of sulfur from insoluble kerogen to soluble bitumen. Even before this event, however, partial elimination of sulfur from the kerogen takes place under mild thermal stress $\left(175^{\circ} \mathrm{C}\right)$, and there is every reason to believe that this also occurs in the natural system within a late diagenetic/early maturation time-frame. For both of these phases of sulfur removal from 
the kerogen, geochemical evidence suggests that the sulfur species responsible are sulfide linkages. Initially, polysulfide bridges may collapse, liberating $\mathrm{H}_{2} \mathrm{~S}$, but little or no bitumen (Fig. 10). These bridges are likely to be the most thermally labile. Subsequently, C-S bonds in mono-sulfide bridges may undergo scission in concert with S-S bond cleavage, releasing polar-rich bitumen. Thus (poly)sulfide linkages are the species which display the greatest reactivity at lower temperatures and likely play a key role in dictating the evolution of petroleum-like products. At higher temperatures, reactions dominated by sulfur bond-breakage give way to those involving carbon-carbon bond scission (Fig. 10). Here we envisage that sulfur plays a subordinate role owing to the fact that most of the labile sulfur is already eliminated from the kerogen at lower temperatures and condensed cyclic forms of sulfur, which are thermodynamically more stable and do not participate significantly in hydrocarbon generation, are more prevalent.

An interesting observation stemming from the present study is the non-linear relationship between the Py-GC based thiophene ratio and $\mathrm{S}_{\text {org }} / \mathrm{C}$ ratio as a function of maturation temperature. A near linear relationship has previously been observed between these parameters for immature kerogens (Sinninghe Damsté and de Leeuw, 1990). Eglinton et al. (Eglinton et al., 1994) also observed this relationship for unconsolidated organic sulfur-rich sediments from the Peru margin, noting that the relation held despite the fact that XANES analysis indicated only a small proportion of the sulfur was thiophenic. These authors postulated that the ratio must reflect total sulfur because of a constancy in the relative abundance of these species over the diagenetic interval studied. Indeed, for Peru margin kerogens, XANES-based speciation was remarkably constant, with sulfides dominating throughout. Like the Peru kerogens, the kerogens from the unheated Monterey shale showed a similar dominance of sulfides, but unlike the former there was a significant shift in the relative proportions of sulfur species as a function of temperature. Consequently, at lower temperatures $\left(<250^{\circ} \mathrm{C}\right)$, the thiophene ratio remained constant while the S/C ratio decreased (Fig. 9). This reflects removal of S from polysulfide bridges (as $\mathrm{H}_{2} \mathrm{~S}$ ), while sulfur more intimately associated with carbon structures remains intact. At higher temperatures, the thiophene ratio shows a more precipitous reduction compared to the S/C ratio, where removal of thiophenic species 
becomes prevalent. The result of these thermally disparate events is a "dog-leg" relationship between the thiophene ratio and the $\mathrm{S} / \mathrm{C}$ ratio. Although systematic decreases in the thiophene ratio as a function of maturity have been previously observed (Eglinton et al., 1990b), this more complex relationship with respect to the S/C ratio has not been reported It is clear, therefore, that caution should be exercized when using the Py-GC approach for estimating organic sulfur contents of kerogens spanning a wide maturity range.

\section{Conclusions}

Hydrous-pyrolysis experiments, when combined with an analytical scheme involving XANES spectroscopy, Py-GC, CP/MAS ${ }^{13} \mathrm{C}$ NMR spectrometry, elemental analysis, TLC-FID and relected light microscopy, represents an effective means to determine the speciation of sulfur during maturation of the Monterey shale. The following conclusions regarding gross and molecular-level transformations in sulfur speciation and the manner by which they lead to the early conversion of kerogen to bitumen and oil are made:

1. The high sulfur content of Monterey kerogen leads to relatively low temperature (polar) bitumen $\left(275^{\circ} \mathrm{C}\right)$ and (saturate and aromatic hydrocarbons) oil (325$360^{\circ} \mathrm{C}$ ) generation as compared to sulfur-poor kerogens during experiments.

2. XANES spectroscopic analyses indicate that sulfides and polysulfides are the major forms of organic sulfur initially present in the Monterey Shale kerogen. Removal of these sulfur species from the kerogen begins at very low temperatures $\left(150^{\circ} \mathrm{C}\right)$, with qualitative evidence indicating preferential elimination of polysulfides. The relative amount of organic sulfides and polysulfides increases in the bitumen fraction to a maximum at $275^{\circ} \mathrm{C}$, whereas the relative proportion of total thiophenes in both the kerogen and bitumen fractions show comparatively little change with temperature. The early generation of bitumen is attributed to the inherent weakness of sulfur linkages within kerogen-bound sulfides and, in particular, polysulfides. 
3. The fate of organic sulfur during laboratory thermal maturation of Monterey kerogen can be described in terms of three temperature regimes: (a) $150-225^{\circ} \mathrm{C}$ : (Poly)sulfide bridges collapse, leading to the formation of $\mathrm{H}_{2} \mathrm{~S}$. (b) $225-275^{\circ} \mathrm{C}$ : Scission of sufficient sulfide linkages resulting in the release of soluble sulfur-rich fragments (bitumen) from the kerogen and continued $\mathrm{H}_{2} \mathrm{~S}$ production. (c) $>275^{\circ} \mathrm{C}$ : Cleavage of S-S and $\mathrm{C}-\mathrm{S}$ bonds gives way to $\mathrm{C}-\mathrm{C}$ bond scission and the generation of saturated and aromatic hydrocarbons. At higher temperatures $\left(360^{\circ} \mathrm{C}\right)$ sulfur may no longer be mechanistically important as most of the labile forms have been removed.

\section{Acknowledgments}

The authors would like to thank M. D. Lewan (USGS, Denver, CO) for providing the Monterey Shale sample, S. Wang and F. Lo (BNL, Upton, NY) for assisting with conducting XANES analysis and curve fitting, L. B. Eglinton and N. L. Parmentier for various analyses, and E. Bailey for help with manuscript preparation. This research was funded by U.S. Department of Energy grant \#'s DE-FGO2-86ER13466 (J. K. Whelan, J.S.S.), DE-FGO2-92ER14232 (T.I.E.) and DE-FC21-93MC30127 (F.P.M.) This is Woods Hole Oceanographic Institution contribution number 8948. 


\section{References}

Acholla F.V. and Orr W.L. Energy and Fuels 1993, 7, 406-410.

Baskin D.K. and Peters K.E. Bull. Amer. Assoc. Petrol. Geol. 1992, 76, 1-13.

Canfield D.E., Raiswell R., Westrich J.T., Reaves C.M., Berner R.A. Chem. Geol. 1986, 54, 149-155.

Claxton M.J., Patience R.L. and Park P.J.D. In: Poster sessions from the $16^{\text {th }}$ International meeting on Organic Geochemistry; Stavanger: 1993; pp. 198-201.

Eglinton T.I. and Douglas A.G. Energy and Fuels 1988, 2, 81-88.

Eglinton T.I., Sinninghe Damsté J.S., Kohnen M.E.L. and de Leeuw J.W. Fuel 1990a, 69, 1394-1404.

Eglinton T.I., Sinninghe- Damsté J.S., Kohnen M.E.L., de Leeuw J.W., Larter S.R. and Patience R.L. In: Geochemistry of Sulfur in fossil fuels; Orr, W.L. and White, C.M. Eds.; ACS Symposium Series 429; 1990b; pp. 529-565

Eglinton T.I., Sinninghe Damsté J.S., Pool W., de Leeuw J.W., Eijkel G. and Boon J.J.. Geochim. Cosmochim. Acta 1992, 56, 1545-1560.

Eglinton T.I., Irvine J.E., Vairavamurthy A., Zhou W. and Manowitz B. Org. Geochem. 1994, 22, 781-799.

Gransch J.A. and Posthuma J. In: Advances in organic geochemistry; Tissot, B. and Bienner, F., Eds.; Paris Editions Technip: Paris, 1974; pp 727-739.

Hunt J.M., Lewan M.D. and Hennet R.J-C. Bull. Amer. Assoc. Petrol. Geol. 1991, 75, 795-807.

Karlsen D.A. and Larter S.R. Org. Geochem. 1991, 17, 603-617.

Lewan M.D. Phil. Trans. R. Soc. Lond. A315, 1985, 123-134.

Lewan M.D. In: Organic Geochemistry Principles and Applications; Engel, M.H. and Macko, S.A., Eds; Plenum Press: New York, 1993; pp. 419-442,.

Lo H.B. Org. Geochem. 1993, 20, 653-657.

Lovering E.G. and Laidler K.J. Canadian Jour. Chem. 1960, 38, 2367.

Orr W.L. Org. Geochem. 1986, 10, 499-516.

Orr W.L. and Sinninghe Damsté J.S. In: Geochemistry of Sulfur in Fossil Fuels; Orr, W.L. and White, C.M., Eds.; ACS Symposium Series 429, 1990; pp. 2-24.

Patience R.L, Mann A.L. and Poplett I.J.F. Geochim. Cosmochim. Acta 1992, 56, 27252742.

Robert P. In: Organic Metamorphism and Geothermal History; D. Reidel Publishing Co.: Holland, 1988; pp. 61-129,

Seewald J.S. and Seyfried W.E. Earth Planet. Sci. Lett. 1990, 101, 388-403. 
Sinninghe Damsté J.S., Eglinton T.I., de Leeuw J.W. and Schenck P.A. Geochim. Cosmochim. Acta 1989a, 53, 873-889.

Sinninghe Damsté J.S., Rijpstra W.I.C., Kock-van Dalen A.C., de Leeuw J.W. and Schenck P.A. Geochim. Cosmochim. Acta 1989b, 53, 1343-1355.

Sinninghe Damsté J.S. and de Leeuw J.W. Org. Geochem. 1990, 16, 1077-1101.

Tannenbaum E. and Aizenshtat Z. Org. Geochem. 1984, 6, 503-511.

Teichmuller M. Org. Geochem. 1986, 10, 581-599.

Tissot B. Revue de l'Institut Francais du Petrol. 1984, 39, 561-572.

Vairavamurthy A., Manowitz B., Zhou W. and Jeon Y In: Environmental Geochemistry of Sulfide Oxidation; Alpers, C.N. and Blowes, D.W. Eds.; ACS Symposium Series 550; 1994; pp. 412-430.

Waldo G.S., Carlson R.M.K., Moldowan J.M., Peters K.E. and Penner-Hahn J.E. Geochim. Cosmochim. Acta 1991, 55, 801-814. 
Table 1. Total extract, saturated, aromatic and polar compound yields. Concentrations of dissolved $\mathrm{CO}_{2}+\mathrm{C}_{1}-\mathrm{C}_{3}$ (light hydrocarbon) and $\mathrm{H}_{2} \mathrm{~S}$.

\begin{tabular}{lcccccc}
\hline Temperature $\left({ }^{\circ} \mathbf{C}\right)$ & $\begin{array}{c}\text { Total } \\
(\mathbf{m g} / \mathbf{g} \text { rock })\end{array}$ & $\begin{array}{c}\text { Saturates } \\
(\mathbf{m g} / \mathbf{g} \text { rock })\end{array}$ & $\begin{array}{c}\text { Aromatics } \\
(\mathbf{m g} / \mathbf{g} \text { rock })\end{array}$ & $\begin{array}{c}\text { Polars } \\
(\mathbf{m g} / \mathbf{g} \text { rock })\end{array}$ & $\begin{array}{c}\mathbf{C O}_{2}+\mathbf{C}_{\mathbf{1}}-\mathrm{C}_{\mathbf{3}} * \\
(\mathbf{m g} / \mathbf{g} \text { rock) }\end{array}$ & $\begin{array}{c}\mathbf{H}_{2} \mathrm{~S}^{*} \\
(\mathbf{m g} / \mathbf{g} \text { rock) }\end{array}$ \\
\hline Unheated & 10.7 & 0.0 & 0.0 & 10.7 & n.d. & n.d. \\
125 & 1.23 & 0.0 & 0.0 & 1.23 & 6.01 & n.d. \\
150 & 1.72 & 0.0 & 0.0 & 1.72 & 8.68 & n.d. \\
175 & 7.26 & 0.58 & 0.0 & 6.68 & 13.3 & n.d. \\
200 & 22.4 & 0.11 & 0.27 & 22.0 & 20.7 & n.d. \\
225 & 10.5 & 0.64 & 0.87 & 9.01 & n.d. & n.d. \\
250 & 36.9 & 0.54 & 2.08 & 34.2 & 29.8 & 6.9 \\
275 & 68.4 & 2.69 & 3.70 & 62.0 & n.d. & n.d. \\
300 & 29.7 & 1.60 & 1.45 & 26.6 & 47.9 & 8.4 \\
325 & 29.2 & 3.25 & 4.39 & 21.5 & 50.3 & 9.3 \\
350 & 22.7 & 1.87 & 3.26 & 17.5 & 69.3 & 12.7 \\
360 & 33.1 & 1.21 & 4.81 & 27.1 & 77.4 & 18.8 \\
\hline
\end{tabular}

n.d. not determined.

* calculated from the concentrations of these species dissolved in the aqueous phase. 
Table 2. Elemental Analysis of bulk sediments, $\mathrm{CrCl}_{2}$-treated kerogens and solvent (bitumen) extracts

\begin{tabular}{|c|c|c|c|c|c|c|c|c|c|c|c|c|c|c|}
\hline \multirow[b]{2}{*}{ Temp. $\left({ }^{\circ} \mathrm{C}\right)$} & \multicolumn{4}{|c|}{ Bulk Sediment } & \multicolumn{5}{|c|}{$\mathrm{CrCl}_{2}$-treated Kerogen } & \multicolumn{5}{|c|}{ Bitumen } \\
\hline & $\% \mathrm{OC}$ & $\% \mathrm{~N}$ & $\% \mathrm{~S}$ & $\mathrm{~S} / \mathrm{C}$ & $\% \mathrm{OC}$ & $\% \mathrm{H}$ & $\% \mathrm{~N}$ & $\% \mathrm{~S}$ & $\mathrm{~S} / \mathrm{C}$ & $\% \mathrm{OC}$ & $\% \mathrm{H}$ & $\% \mathrm{~N}$ & $\% \mathrm{~S}$ & $\mathrm{~S} / \mathrm{C}$ \\
\hline Unheated & 20.58 & 1.24 & 3.86 & 0.070 & 60.44 & 6.52 & 3.22 & 8.25 & 0.051 & 68.86 & 8.34 & 2.05 & 7.25 & 0.039 \\
\hline 125 & 22.60 & 1.36 & 3.67 & 0.061 & 59.83 & 6.41 & 3.06 & 7.83 & 0.049 & 56.40 & 5.67 & 2.44 & 5.12 & 0.034 \\
\hline 150 & 23.54 & 1.42 & 3.67 & 0.058 & 59.57 & 6.86 & 2.91 & 7.50 & 0.047 & 67.68 & 7.02 & 2.23 & 6.92 & 0.038 \\
\hline 175 & 22.39 & 1.34 & 3.50 & 0.059 & 60.79 & 6.22 & 3.11 & 7.39 & 0.046 & 69.62 & 8.39 & 1.56 & 8.30 & 0.045 \\
\hline 200 & 22.62 & 1.23 & 3.02 & 0.050 & 64.56 & 6.45 & 3.14 & 6.92 & 0.040 & n.d. & n.d. & n.d. & n.d. & n.d. \\
\hline $225^{*}$ & 18.64 & 1.08 & 2.64 & 0.053 & 62.88 & 6.28 & 3.24 & 6.04 & 0.036 & 55.35 & 4.69 & 1.76 & 6.79 & 0.046 \\
\hline 250 & 20.32 & 1.21 & 3.06 & 0.056 & 60.81 & 5.99 & 2.93 & 5.21 & 0.032 & 68.66 & 7.59 & 1.68 & 10.8 & 0.059 \\
\hline $275^{*}$ & 15.58 & 0.94 & 2.36 & 0.057 & 69.13 & 5.74 & 3.60 & 4.49 & 0.024 & 71.98 & 8.25 & 2.27 & 10.4 & 0.054 \\
\hline 300 & 18.31 & 1.12 & 2.24 & 0.046 & 72.55 & 5.66 & 3.70 & 3.91 & 0.020 & 55.95 & 6.72 & 1.35 & 6.61 & 0.044 \\
\hline 325 & 16.71 & 0.97 & 2.21 & 0.050 & 75.26 & 5.03 & 3.95 & 3.40 & 0.017 & 72.55 & 7.92 & 1.62 & 9.64 & 0.050 \\
\hline 350 & 15.08 & 0.90 & 1.81 & 0.045 & 65.22 & 4.39 & 3.54 & 2.94 & 0.017 & n.d. & n.d. & n.d. & n.d. & n.d. \\
\hline 360 & 14.58 & 0.98 & 2.44 & 0.063 & 74.79 & 4.23 & 4.01 & 3.48 & 0.017 & 76.48 & 6.86 & 2.06 & 7.61 & 0.037 \\
\hline
\end{tabular}

* Sediment samples were not decarbonated prior to hydrous-pyrolysis.

n.d. not determined. 
Table 3. NMR results of bulk sediments, isolated kerogens and $\mathrm{CrCl}_{2}$-treated kerogens and "bituminite" reflectance of bulk sediments

\begin{tabular}{|c|c|c|c|c|}
\hline \multirow[b]{2}{*}{ Temperature $\left({ }^{\circ} \mathrm{C}\right)$} & \multicolumn{3}{|c|}{ Aromaticity* } & \multirow{2}{*}{$\begin{array}{c}\% \mathrm{R}_{\mathrm{o}} \\
\text { Bulk } \\
\text { Sediment }\end{array}$} \\
\hline & $\begin{array}{c}\text { Bulk } \\
\text { Sediment }\end{array}$ & Kerogen & $\begin{array}{c}\mathrm{CrCl}_{2} \text {-treated } \\
\text { Kerogen }\end{array}$ & \\
\hline Unheated & 0.35 & 0.34 & n.d. & 0.25 \\
\hline 125 & 0.32 & 0.35 & 0.32 & 0.24 \\
\hline 150 & 0.36 & 0.32 & 0.33 & 0.28 \\
\hline 175 & 0.41 & 0.37 & 0.36 & 0.31 \\
\hline 200 & n.d. & n.d. & n.d. & 0.30 \\
\hline 225 & 0.44 & n.d. & n.d. & 0.29 \\
\hline 250 & 0.45 & 0.49 & 0.49 & 0.36 \\
\hline 275 & 0.57 & n.d. & n.d. & 0.33 \\
\hline 300 & 0.64 & 0.59 & 0.63 & 0.42 \\
\hline 325 & 0.67 & n.d. & n.d. & 0.59 \\
\hline 350 & n.d. & n.d. & n.d. & 0.85 \\
\hline 360 & 0.88 & 0.83 & 0.83 & 0.95 \\
\hline
\end{tabular}

* may include any contributions from carboxylate and carbonyl carbons if present. n.d. not determined. 
Table 4. Peak identifications for FPD chromatograms

\begin{tabular}{|c|c|c|c|c|c|}
\hline Peak & Compound & Origin* & Peak & Compound & Origin* \\
\hline 1 & Hydrogen sulfide & ? & 16 & 2-ethyl-4-methylthiophene & B \\
\hline 2 & Thiophene & $?$ & 17 & 2,3,5-trimethylthiophene & $\mathrm{I}, \mathrm{B}$ \\
\hline 3 & 2-Methylthiophene & $\mathrm{L}$ & 18 & 2-methyl-5-ethenylthiophene & $\mathrm{L}$ \\
\hline 4 & 3-Methylthiophene & I & 19 & 2,3,4-trimethylthiophene & $\mathrm{B}, \mathrm{S}$ \\
\hline 5 & Thiolane & $?$ & 20 & 3-isopropyl-2-methylthiophene & S \\
\hline 6 & Methyldihydrothiophene & $\mathrm{L}$ & 21 & 2-methyl-5-propylthiophene & $\mathrm{L}$ \\
\hline 7 & 2-methylthiolane & $\mathrm{L}$ & & +2,5-diethylthiophene & $\mathrm{L}$ \\
\hline 8 & 2-ethylthiolane & $\mathrm{L}$ & 22 & 5-ethyl-2,3-dimethylthiophene & $\mathrm{B}$ \\
\hline 9 & 2,5-dimethylthiophene & $\mathrm{L}$ & 23 & Unknown & S? \\
\hline 10 & 2,4-dimethylthiophene & $\mathrm{B}, \mathrm{S}$ & 24 & 2-butyl-5-methylthiophene & $\mathrm{L}$ \\
\hline 11 & 2-ethenylthiophene & 1 & 25 & 2-ethyl-5-butylthiophene & $\mathrm{L}$ \\
\hline 12 & 2,3-dimethylthiophene & $\mathrm{I}, \mathrm{B}$ & 26 & 2-methyl-5-pentylthiophene & $\mathrm{L}$ \\
\hline 13 & 2-ethylthiolane & $\mathrm{L}$ & 27 & 2-methylbenzo $[\beta]$ thophene & $\mathrm{L}$ \\
\hline 14 & 2-propylthiophene & $\mathrm{L}$ & 28 & 4-methylbenzo[$[\beta]$ thiophene & L \\
\hline 15 & 2-ethyl-5-methylthiophene & $\mathrm{L}$ & & +3 -methylbenzo $[\beta]$ thiophene & B \\
\hline
\end{tabular}

* Inferred carbon skeleton of bound precursor: $\mathrm{L}=$ linear, $\mathrm{B}=$ branched, $\mathrm{I}=$ isoprenoid, $\mathrm{S}=$ steroid side chain. 


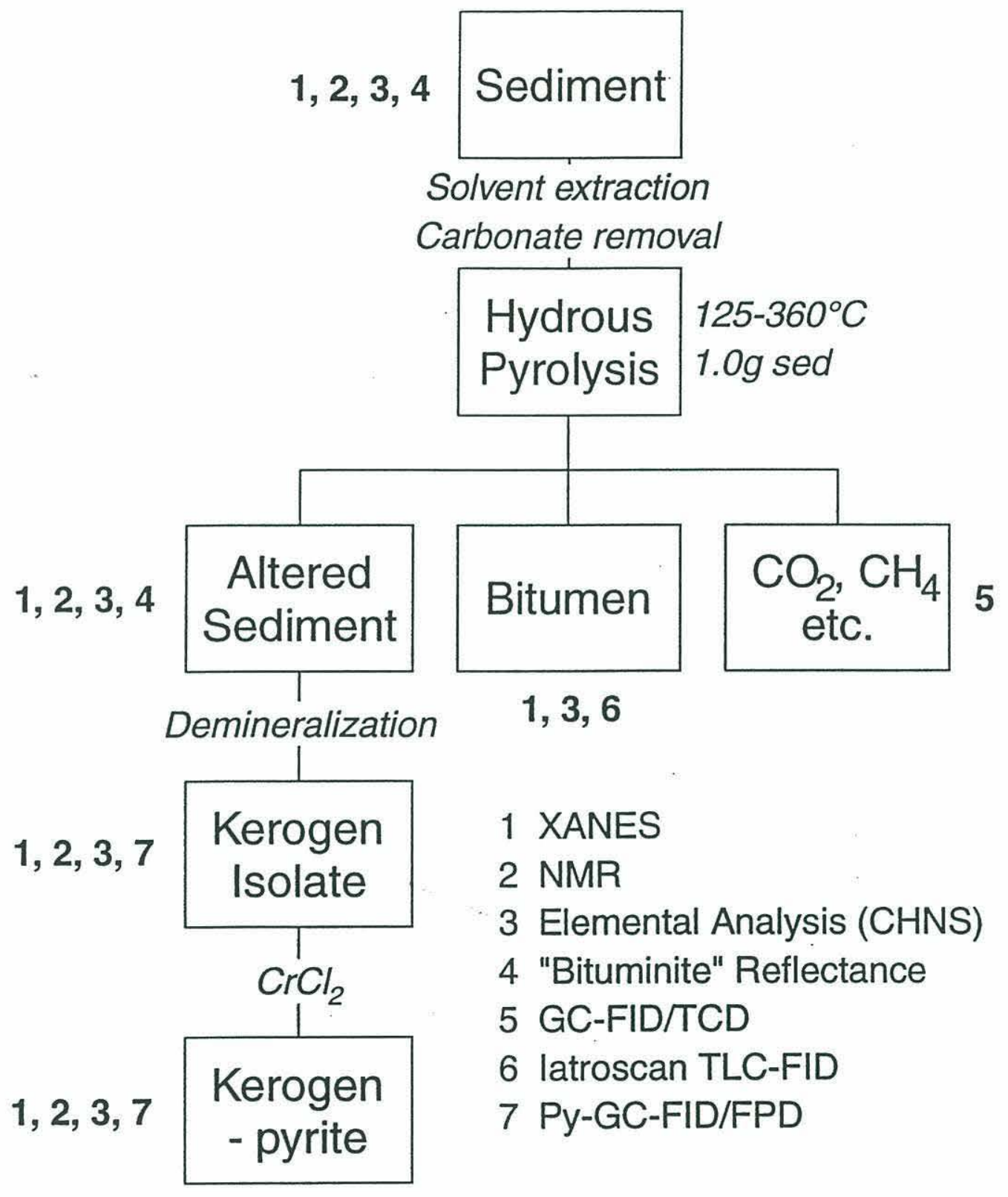

Figure 1. Outline of analytical scheme for separation and characterization of hydrouspyrolysis products. 


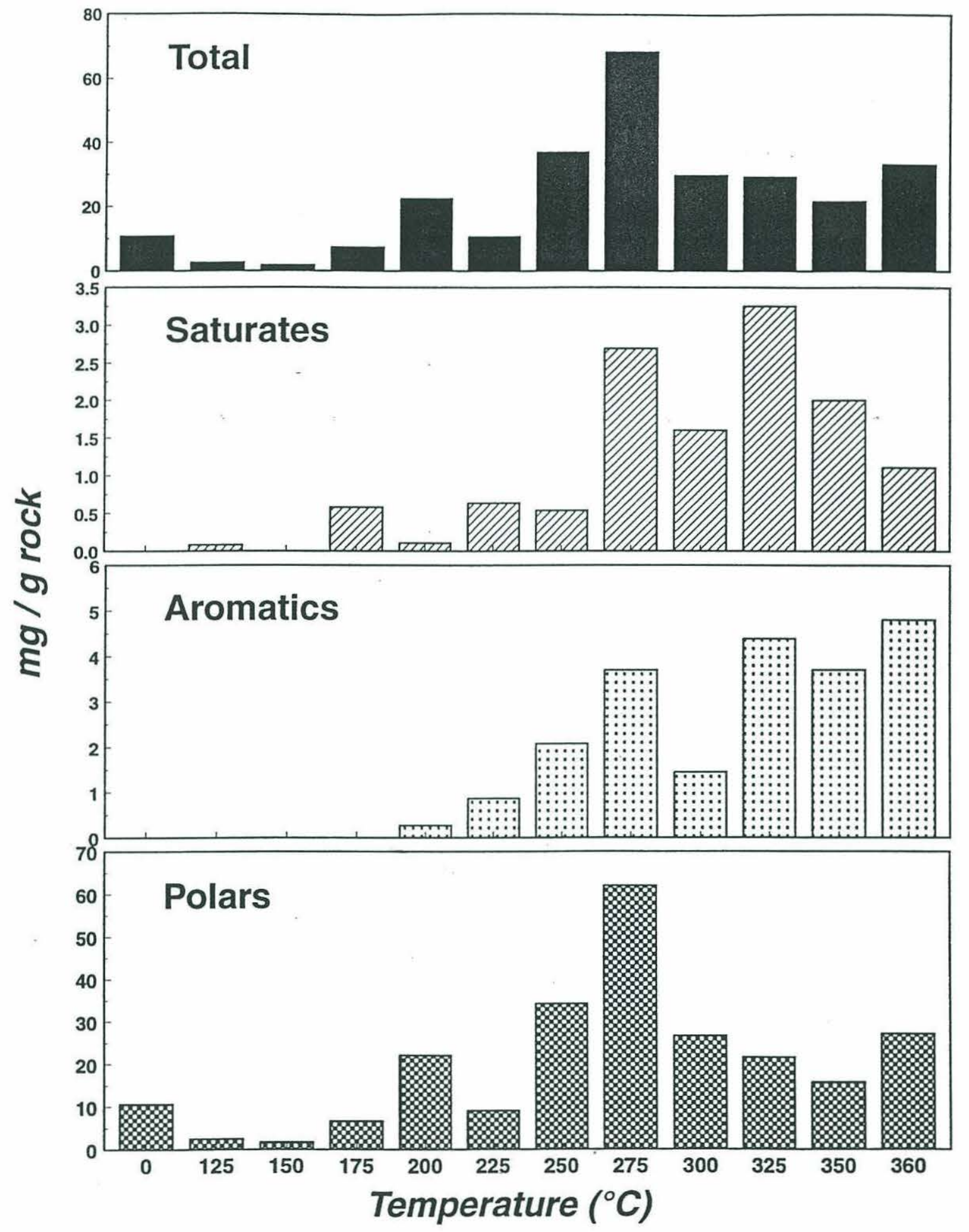

Figure 2. Bar charts showing yields of total extract, saturated, aromatic and polar compound classes for the soluble (bitumen) products from each hydrous-pyrolysis experiment. 


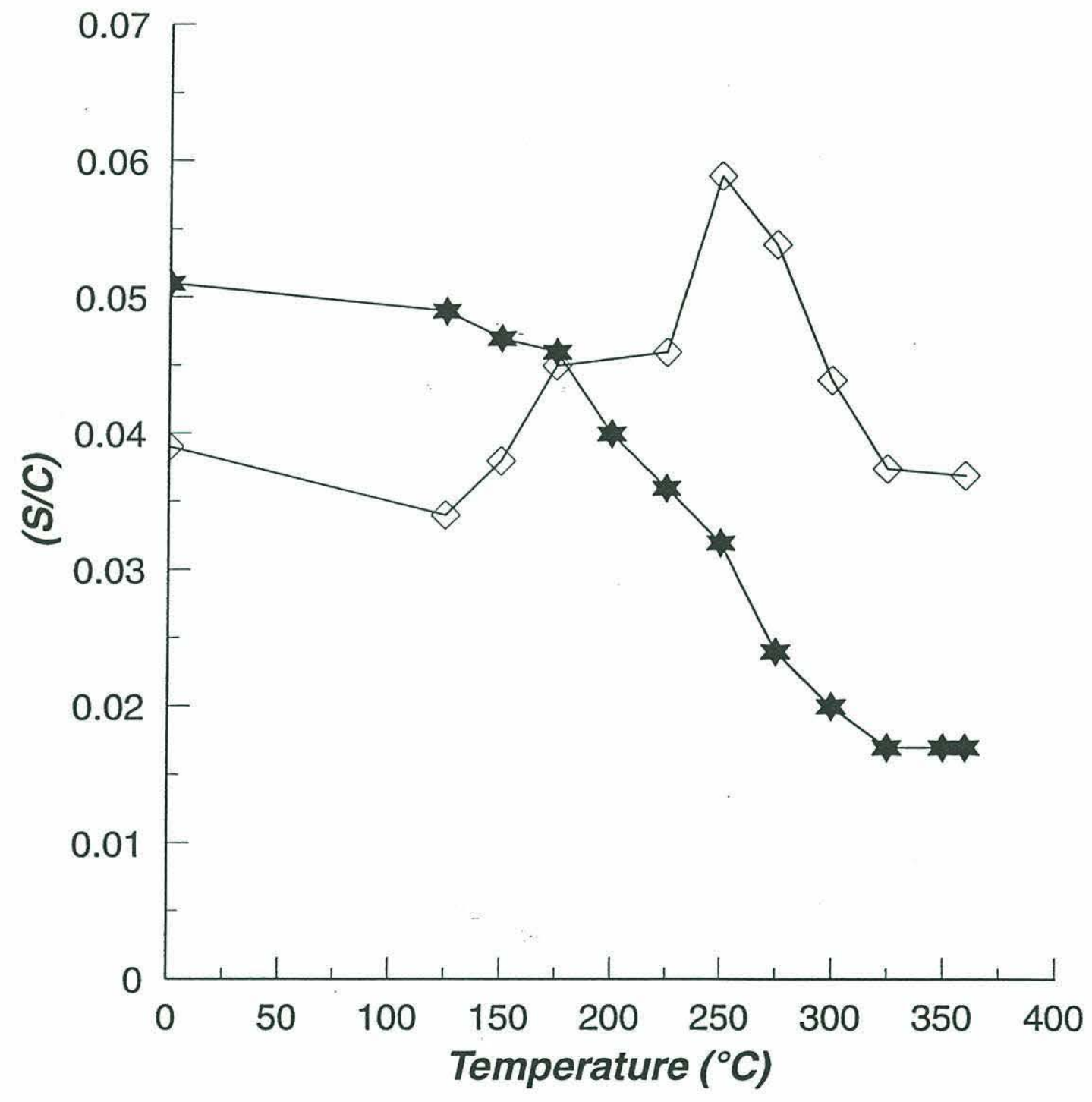

Figure 3. Variation in the atomic $\mathrm{S} / \mathrm{C}$ ratio of the bitumen (open diamonds) and $\mathrm{CrCl}_{2}$ treated kerogens (closed stars) with temperature. 


\section{Bitumen}

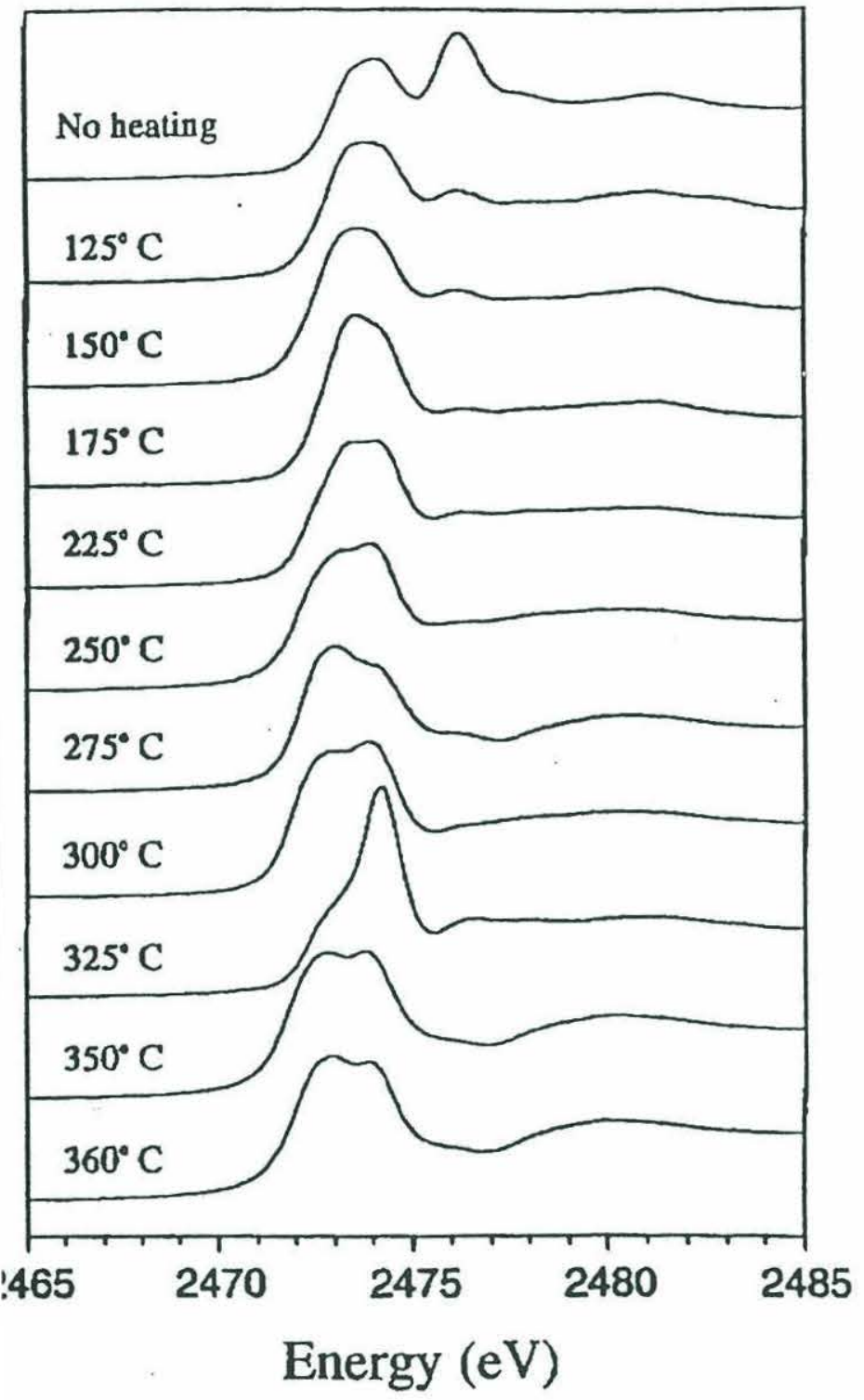

- $\mathrm{CrCl}_{2}$-treated kerogen

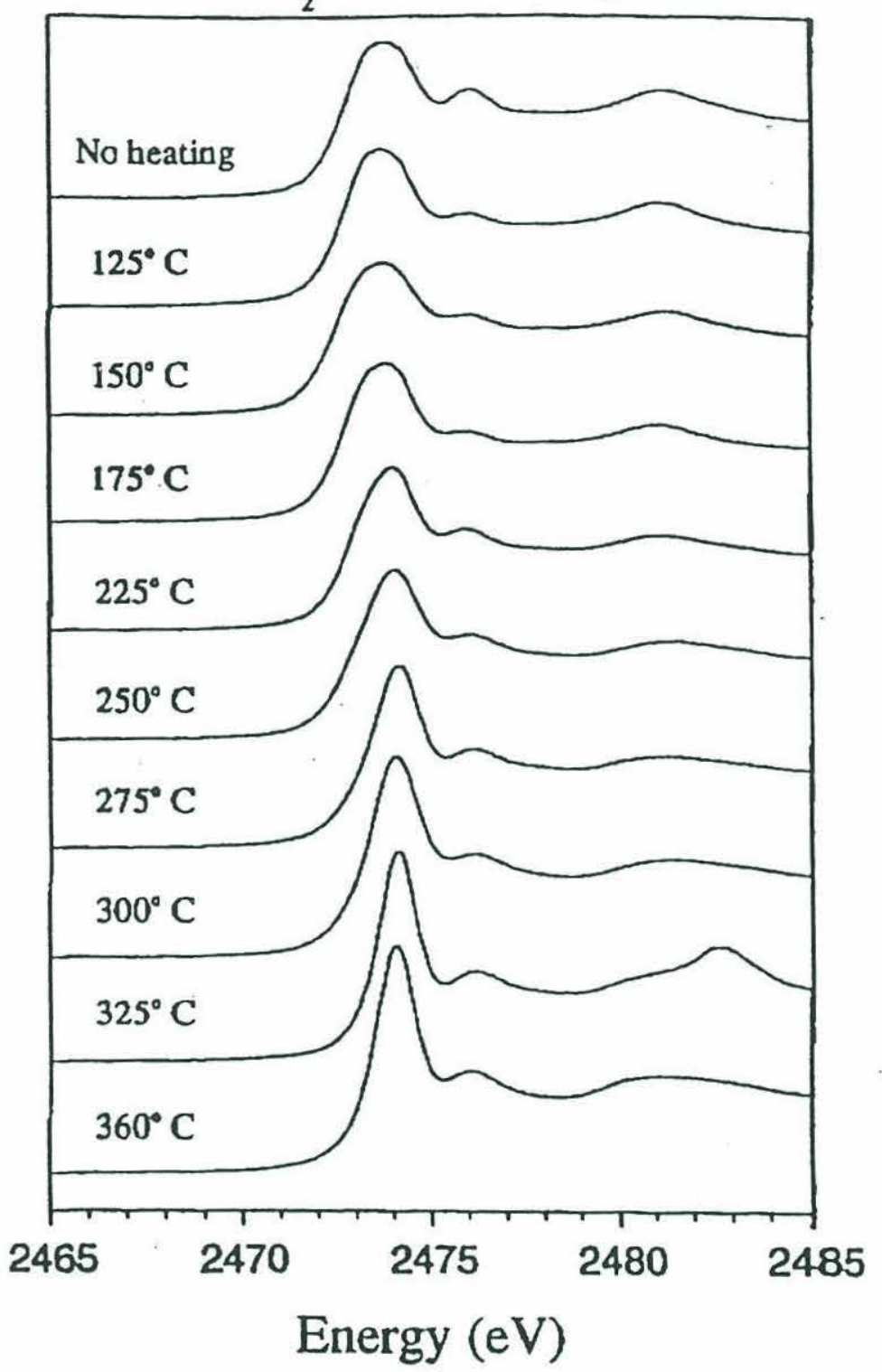

Figure 4. Normalized XANES spectra of (a) bitumen from the unheated, $125^{\circ} \mathrm{C}, 150^{\circ} \mathrm{C}$, $175^{\circ} \mathrm{C}, 225^{\circ} \mathrm{C}, 250^{\circ} \mathrm{C}, 275^{\circ} \mathrm{C}, 300^{\circ} \mathrm{C}, 325^{\circ} \mathrm{C}, 350^{\circ} \mathrm{C}$ and $360^{\circ} \mathrm{C}$ hydrouspyrolysis experiments, and (b) $\mathrm{CrCl}_{2}$-treated kerogens from the unheated, $125^{\circ} \mathrm{C}$, $150^{\circ} \mathrm{C}, 175^{\circ} \mathrm{C}, 225^{\circ} \mathrm{C}, 250^{\circ} \mathrm{C}, 275^{\circ} \mathrm{C}, 300^{\circ} \mathrm{C}, 325^{\circ} \mathrm{C}$ and $360^{\circ} \mathrm{C}$ experiments. 

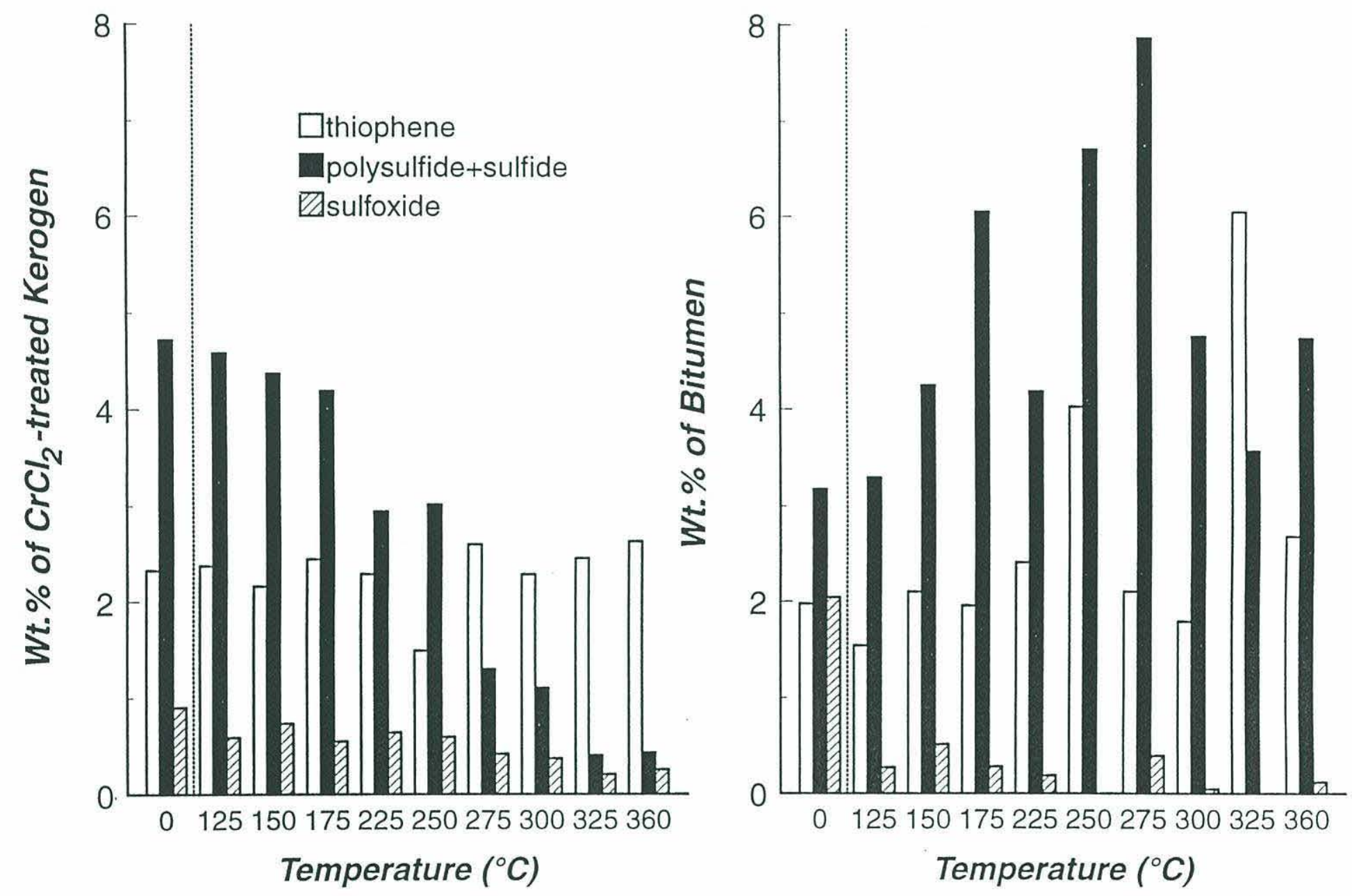

Figure 5. XANES-based sulfur speciation in the (a) $\mathrm{CrCl}_{2}$-treated kerogen and (b) bitumen fractions. 


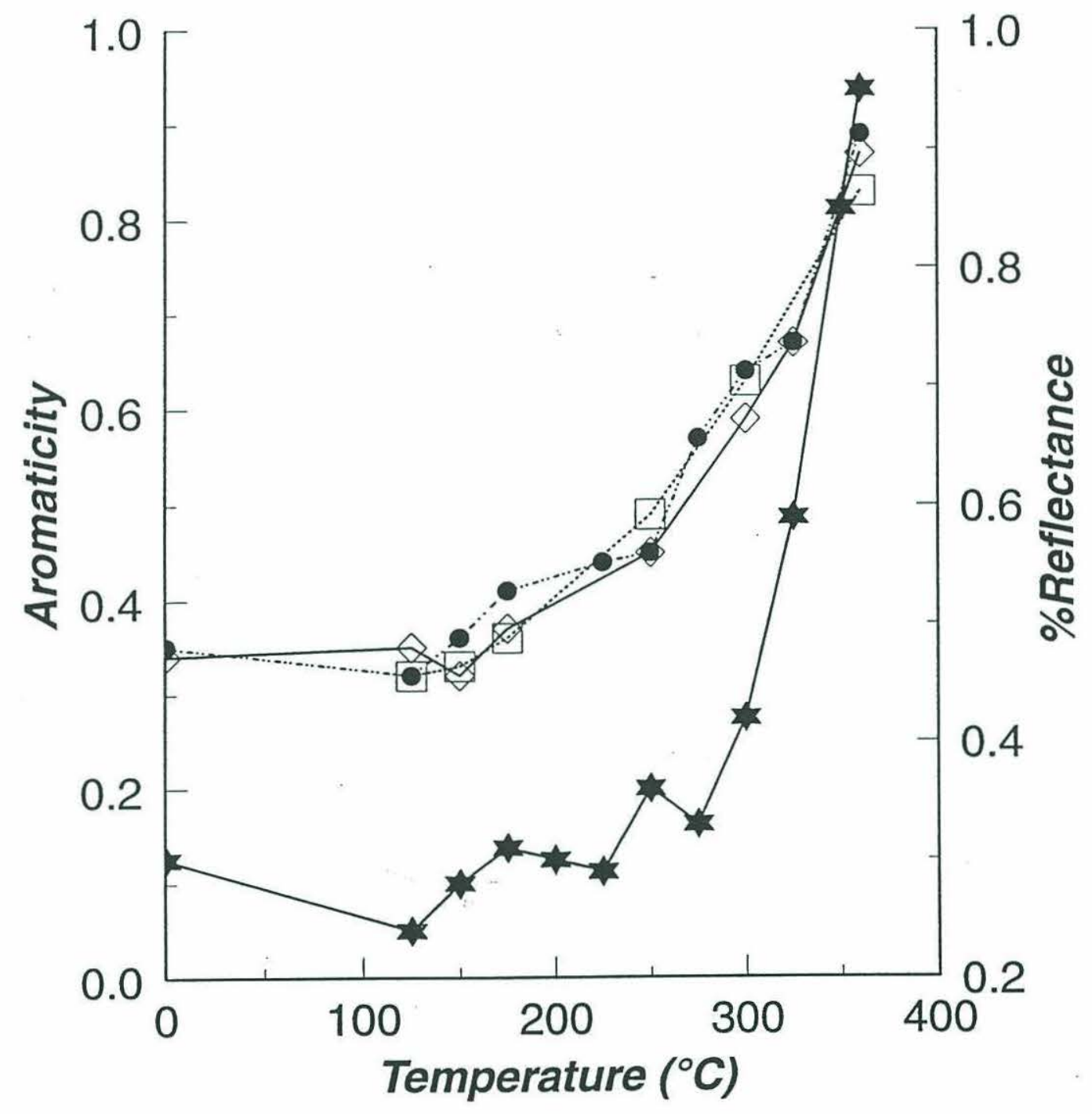

Figure 6. Variation in aromaticity (may include any contributions from carboxylate carbons at $\sim 175 \mathrm{ppm}$ ) of kerogen, $\mathrm{CrCl}_{2}$-treated kerogen and altered sediment fractions as well as variation in reflectance of altered sediments with temperature. Symbols represent: (Aromaticity) open diamonds kerogens, open squares pyritefree kerogen, closed circles altered sediments; $\left(\% \mathrm{R}_{0}\right)$ closed stars altered sediments. 


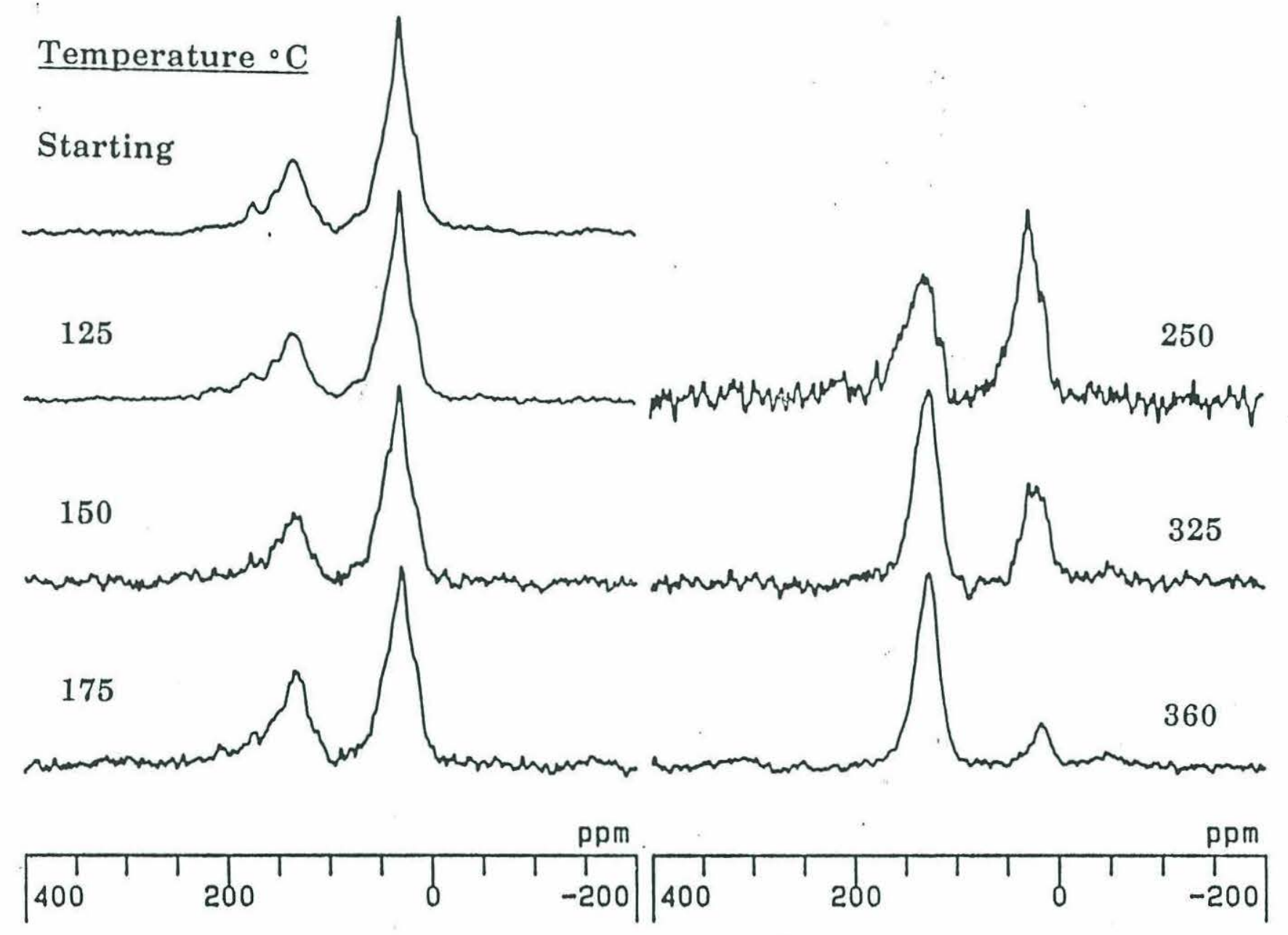

Figure 7. Solid-state ${ }^{13} \mathrm{C} C \mathrm{CP}$-MAS NMR spectra of the kerogen isolates from the unheated, $125^{\circ} \mathrm{C}, 150^{\circ} \mathrm{C}, 175^{\circ} \mathrm{C}, 250^{\circ} \mathrm{C}, 325^{\circ} \mathrm{C}$ and $360^{\circ} \mathrm{C}$ experiments. 

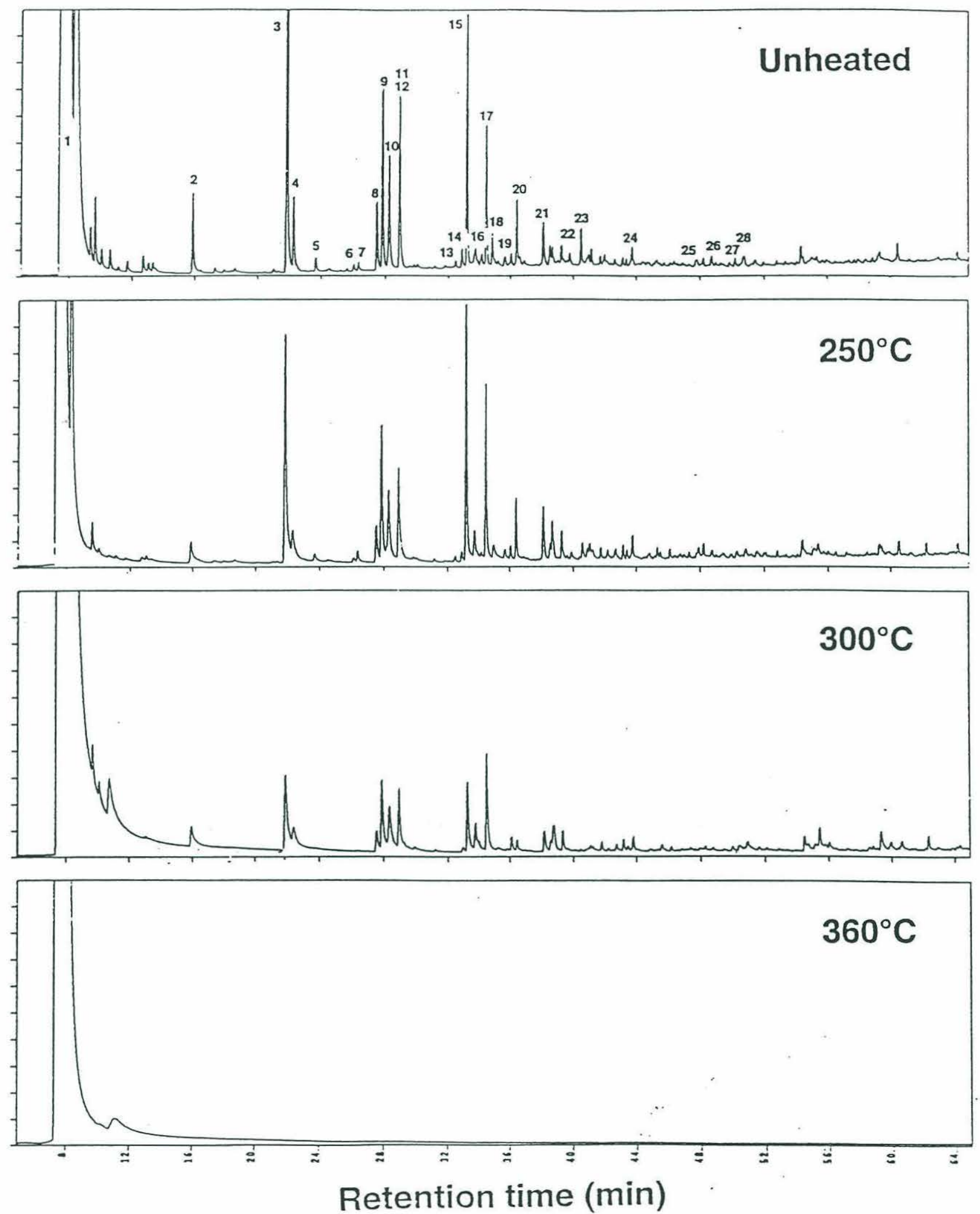

Figure 8. (a) Partial FID chromatograms from Py-GC of the kerogen isolates from the unheated, $250^{\circ} \mathrm{C}, 300^{\circ} \mathrm{C}$ and $360^{\circ} \mathrm{C}$ hydrous-pyrolysis experiments. Numbers represent $n$-hydrocarbon homologs, symbols denote: closed circles alkylbenzenes, open circles thiophenes. 

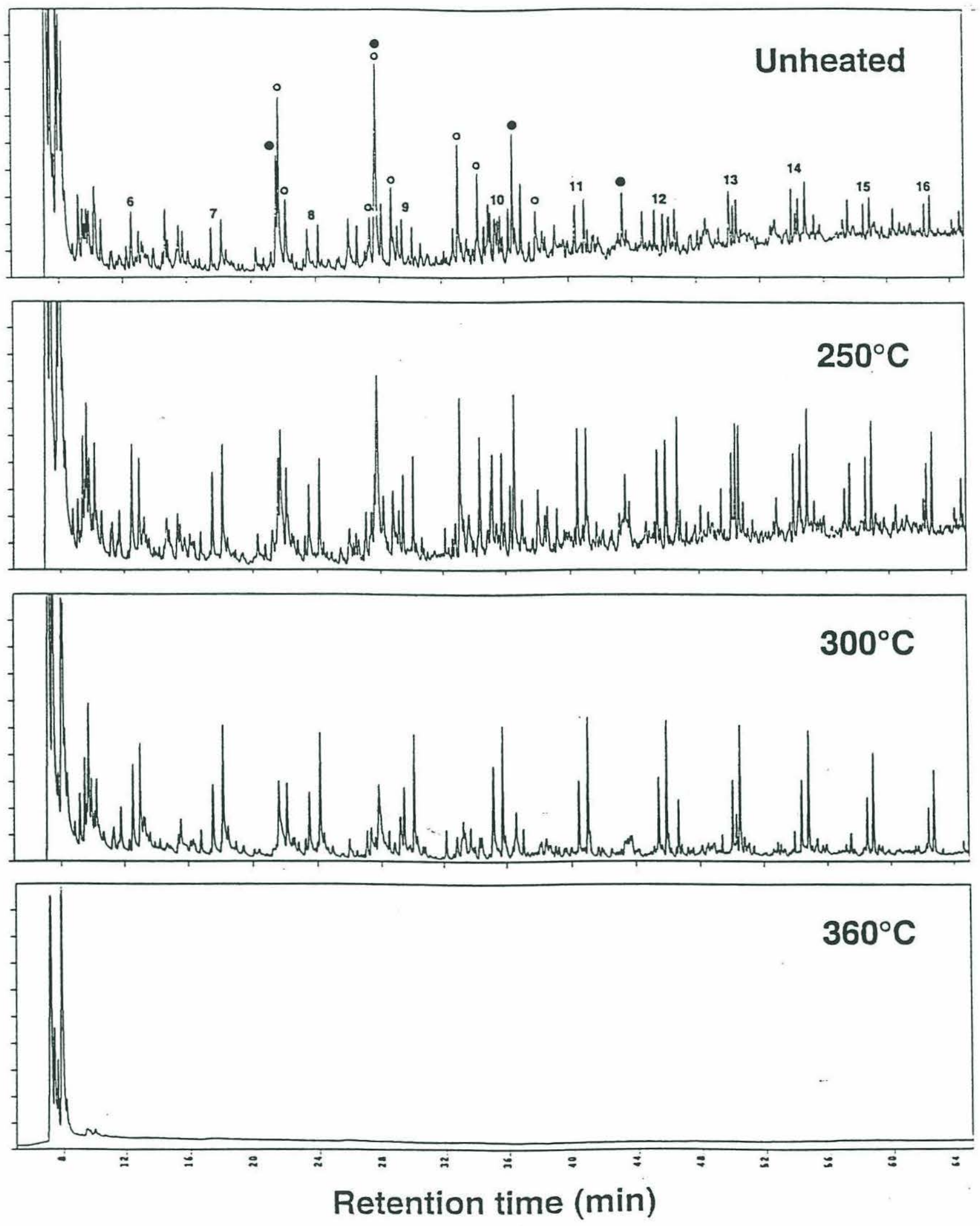

Figure 8. (b) Partial FPD chromatograms from Py-GC of the kerogen isolates from the unheated, $250^{\circ} \mathrm{C}, 300^{\circ} \mathrm{C}$ and $360^{\circ} \mathrm{C}$ hydrous-pyrolysis experiments. Peak assignments are listed in Table 4. 

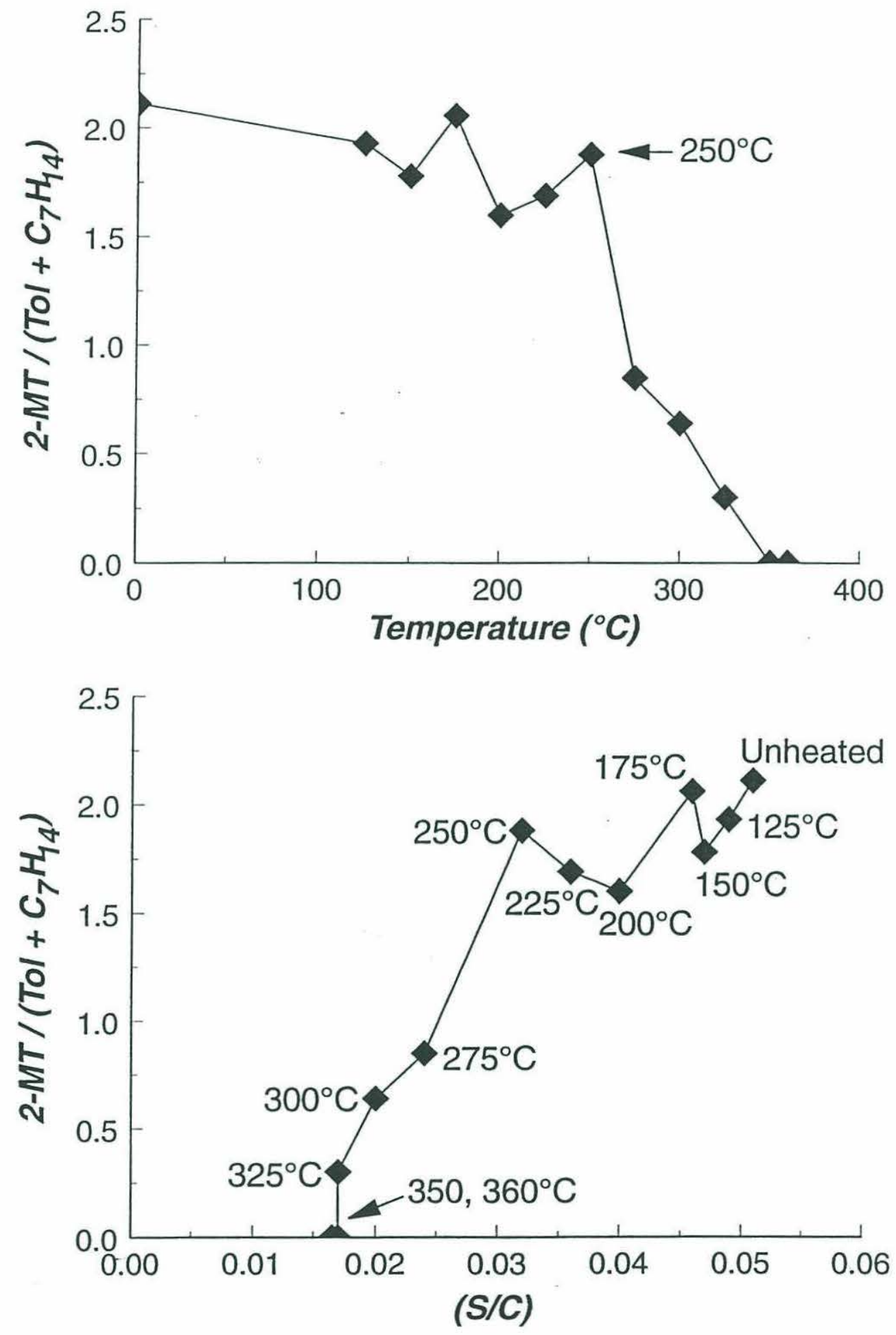

Figure 9. Assessment of the relative abundance of thiophenes in Py-GC (FID) traces of $\mathrm{CrCl}_{2}$-treated kerogens from each hydrous-pyrolysis experiment (expressed as the ratio of [2-methylthiophene/(toluene $+\mathrm{C}_{7} \mathrm{H}_{14}$ )] ) with (a) temperature and (b) atomic S/C ratio. 


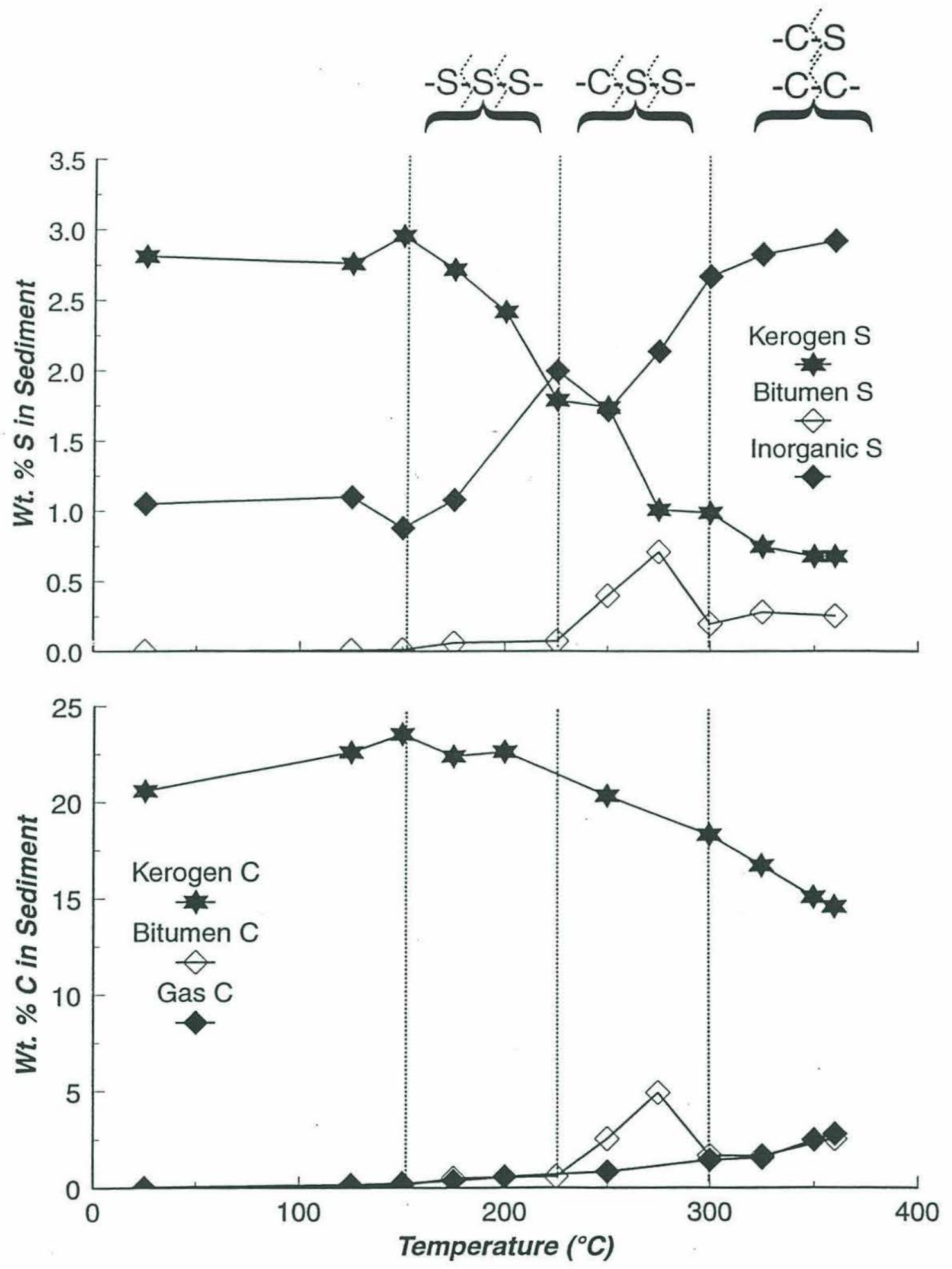

Figure 10. Variation in total sedimentary (a) sulfur and (b) carbon with temperature. 


\section{CHAPTER 2}

\section{Chemical Mechanisms of Hydrocarbon and Non-hydrocarbon Gas Generation During Laboratory Hydrous-pyrolysis of Monterey and Smackover shales}

\section{Introduction}

The desire of the oil industry to maximize the yield of petroleum products obtained from drilling operations has provided sufficient economic incentive to study petroleum generation and expulsion. Unfortunately, sedimentary basins present a complex environment for researchers interested in modeling the extent and timing of oil and gas generation. Time and temperature are important factors controlling petroleum generation yet it is difficult to accurately determine the extent of thermal stress and resulting organic transformations that a source rock has undergone. Consequently, the mechanisms which lead to oil generation and expulsion are obscured in natural settings.

Artificial maturation experiments conducted under both dry conditions (Harwood, 1977; Tissot et al., 1987) and in the presence of water (Lewan, 1985, 1992; Tannenbaum and Kaplan, 1985; Seewald, 1994) have helped to reveal the physical and chemical processes responsible for hydrocarbon generation. Although elevated temperatures are necessary during laboratory studies to compensate for vastly disparate time scales (hours vs. millions of years), hydrous-pyrolysis experiments have yielded petroleum products which are very similar to those observed in sedimentary basins (Lewan, 1985; 1992). Furthermore, the chemical mechanisms leading to the generation of oil during hydrouspyrolysis experiments appear to be the same as those occurring in natural petroleum formations (Lewan, 1992). Thus, experimental simulations have enabled researchers to develop chemical kinetic models of petroleum generation and expulsion in sedimentary basins (Lewan, 1985; Horsfield et al., 1992; Sweeney et al., 1995).

The amounts and distribution of light hydrocarbons $\left(\mathrm{C}_{1}-\mathrm{C}_{4}\right)$, and other gases such as $\mathrm{CO}_{2}, \mathrm{H}_{2} \mathrm{~S}$ and $\mathrm{H}_{2}$, can provide further insight into the organic transformations occurring during source rock maturation. It has been proposed that these gas products may play an important role in the migration of oil over time scales on the order of years 
(Price et al., 1983; Whelan et al., 1994). Only recently, however, have researchers been able to duplicate the composition of natural gas during laboratory pyrolysis (Mango et al., 1994). Attempts to accurately monitor the generation of gaseous products have been hampered by the lack of an ideal experimental apparatus. For example, in studies utilizing a Parr-type hydrous-pyrolysis system (Lewan, 1985), both liquid and vapor phases are present making it difficult to accurately analyze gas samples while at experimental conditions. It is only possible to measure gas concentrations once the experiment has been cooled. The quenching process, however, may initiate chemical reactions which alter the concentration and distribution of generated hydrocarbons. Open pyrolysis systems, on the other hand, allow for continuous measurement of released hydrocarbons. Secondary reactions involving the cracking of oil to gas do not take place, however, because the reaction chamber is continuously swept with carrier gas, removing volatile products (Ungerer, 1990). Furthermore, the lack of water, low pressures and extremely high temperatures $\left(>450^{\circ} \mathrm{C}\right)$ involved are not characteristic of natural environments (Ungerer, 1990). To circumvent these problems a hydrous-pyrolysis system with no head space and only a single liquid phase present was constructed. This experimental set-up allows dissolved gas concentrations and organic acid anions to be sampled while at experimental temperature and pressure. Thus, fluid chemistry can be monitored as a function of time during an individual experiment.

The primary goal of this study was to determine the chemical processes which regulate the rate and extent of chemical reactions responsible for the generation of gaseous products. In order to compare the effects of initial kerogen composition on gas generation, samples of Monterey and Smackover shales were used. A series of hydrouspyrolysis experiments were conducted for $170 \mathrm{hrs}$ at temperatures ranging from 125 to $360^{\circ} \mathrm{C}$. The dissolved concentrations of $\mathrm{C}_{1}-\mathrm{C}_{4}$ hydrocarbons, $\mathrm{CO}_{2}, \mathrm{H}_{2} \mathrm{~S}$ and $\mathrm{H}_{2}$ were monitored during each heating experiment. In addition, elemental analyses of the bulk sediment and kerogen isolates were carried out at the end of each experiment. The results from these measurements have enabled us to further constrain the mechanisms leading to gas generation during source rock maturation. 


\section{Methods}

\section{Sample Description and Preparation}

The Monterey shale sample is a thermally immature (Bituminite reflectance $=$ $0.25 \%$ ), organic rich $(\mathrm{TOC}=20.6 \mathrm{wt} . \%)$ consolidated sediment from the Miocene, Monterey Fm. (Sample \# ML91-17, provided by M.D. Lewan). The sample was obtained from an outcrop at Naples Beach, CA where it was removed from a $10 \mathrm{~cm}$ interval at the base of Unit 315 , approximately $9 \mathrm{~m}$ below the lowest phosphorite horizon. The sample comprised a lenticularly laminated claystone and visually appeared fresh (i.e.

unweathered) and blocky. The Monterey shale kerogen is comprised primarily of sulfurrich marine organic matter (Orr, 1986). Due to its high sulfur content (wt.\% S = 8.25) and petrographic features the Monterey shale kerogen is classified as a type II-S kerogen (Orr, 1986).

The Smackover shale is a consolidated sediment sample from the Jurassic, Upper Smackover Fm. It was obtained from core cuttings retrieved at $3260 \mathrm{~m}$ depth from the Amerada Scotch Well \#1 in Clark County, Al. The sample is relatively organic lean (TOC $=0.917 \mathrm{wt} . \%$ ) contains very little sulfur and has a vitrinite reflectance value of $0.52 \% \mathrm{R}_{\mathrm{o}}$. The Smackover shale kerogen is primarily terrestrial in origin and petrographic evidence indicates that the sample is a type III kerogen.

In this study we were interested in the chemical processes leading to gas generation. Complications due to the physical processes associated with the expulsion of gas were minimized by pulverizing the samples in a disc mill to $<125 \mu \mathrm{m}$ after scraping to expose pristine material. After pulverization, the ground sediment was solvent extracted to remove indigenous hydrocarbons. The Monterey shale sample was sequentially extracted by sonic disruption for $9 \min$ in $\mathrm{CH}_{2} \mathrm{Cl}_{2}$, a 1:1 mixture of $\mathrm{CH}_{2} \mathrm{Cl}_{2} / \mathrm{CH}_{3} \mathrm{OH}$ and $\mathrm{CH}_{3} \mathrm{OH}$. The Smackover sample was soxhlet-extracted for $48 \mathrm{hrs}$ using a 93:7 $\mathrm{CH}_{2} \mathrm{Cl}_{2} / \mathrm{CH}_{3} \mathrm{OH}$ mixture. With the exception of the 225 and $275^{\circ} \mathrm{C}$ heating experiments, both the Monterey and Smackover shales were treated with $10 \% \mathrm{HCl}$ at $40^{\circ} \mathrm{C}$ for $2 \mathrm{hrs}$ to remove sedimentary carbonate. 


\section{Hydrous-pyrolysis Experiments}

$1.0 \mathrm{~g}$ of solvent-extracted, carbonate-free sediment was used as starting material for each experiment except MS9 in which $0.5 \mathrm{~g}$ was used. The sediment sample was loaded into a $20 \mathrm{~mL}, 316$ stainless-steel pipe-bomb, sealed and placed into a horizontal 62 $x 12.0 \mathrm{~cm}$ i.d. furnace (Fig. 1). The air in the pipe-bomb was evacuated and the pipebomb was partially filled with argon-purged distilled water to ensure that the sediment was in contact with water during heating. After the desired experimental temperature was reached ( $30 \mathrm{~min})$, the pipe-bomb was filled completely with distilled water and pressurized to 350 bars so that only a single liquid phase was present (i.e., no headspace). Temperature was monitored $\left( \pm 2^{\circ} \mathrm{C}\right)$ with a thermocouple at each end of the pipebomb to ensure there were no thermal gradients. A wide range in hydrous-pyrolysis temperatures $\left(125-360^{\circ} \mathrm{C}\right)$ was chosen in order to clearly define the amount of thermal stress necessary for significant gas generation. All experiments were approximately 170 hrs in duration.

During an experiment, fluid samples were withdrawn from the pipe-bomb through a $10 \mu \mathrm{m}$ stainless-steel mesh filter into glass gas-tight syringes after approximately 24,72 and 170 hrs. Pressure was maintained during the sampling process by pumping argonpurged distilled water into one end of the pipe-bomb while the fluid sample was removed from the other. During sampling, an initial $0.5 \mathrm{~mL}$ of fluid was removed to clean the stainless-steel lines and valve. Duplicate fluid samples were then removed to measure dissolved hydrocarbon and $\mathrm{CO}_{2}$ concentrations, followed by individual fluid samples for $\mathrm{H}_{2} \mathrm{~S}, \mathrm{H}_{2}$ and organic acid anion measurements. The sampling process was performed rapidly ( 1 to $2 \mathrm{~min}$ ) to avoid dilution of fluid samples with the freshly injected water.

At the end of the experiment the pipe-bomb was cooled and all liquid contents were removed by sequentially pumping $30 \mathrm{~mL}$ of $\mathrm{CH}_{3} \mathrm{OH}$ and $\mathrm{CH}_{2} \mathrm{Cl}_{2}$ through the pipebomb. The pipe-bomb was opened and the solid residue was removed by rinsing with additional solvent. The combined $\mathrm{CH}_{3} \mathrm{OH} / \mathrm{CH}_{2} \mathrm{Cl}_{2}$ extract was centrifuged and the liquid products decanted. After drying at $40^{\circ} \mathrm{C}$ in air, the solid residue was sequentially extracted by sonic disruption in $\mathrm{CH}_{3} \mathrm{OH} / \mathrm{CH}_{2} \mathrm{Cl}_{2}$ to ensure complete removal of generated bitumen. After extraction, a split of the altered sediment $(\sim 350 \mathrm{mg})$ was demineralized 
through $\mathrm{HCl}$ and $\mathrm{HF}$ acid digestions at room temperature (Eglinton and Douglas, 1988) to obtain a kerogen isolate. An aliquot ( $50 \mathrm{mg})$ of the kerogen isolate was treated with $\mathrm{CrCl}_{2}$ and concentrated $\mathrm{HCl}$ to remove inorganic sulfur (Acholla and Orr, 1993).

\section{Analytical Procedures}

Dissolved $\mathrm{CO}_{2}$ and $\mathrm{C}_{1}-\mathrm{C}_{4}$ hydrocarbons were analyzed using a purge and trap apparatus interfaced to a Hewlett Packard 5890 Series II gas chromatograph (GC), fitted with a flame ionization and a thermal conductivity detector in series. Fluid samples were injected into the purge cell which was filled with $1 \mathrm{~mL}$ of $25 \% \mathrm{H}_{3} \mathrm{PO}_{4}$ and purged for 20 min. This ensured complete evolution of dissolved $\mathrm{CO}_{2}$. Evolved gases were trapped cryogenically in a chill loop packed with $n$-octane/porasil $\mathrm{C}$ and then injected the GC. Chromatographic separation was accomplished using either a porapak-Q packed column or a poraplot-Q megabore capillary column. Authentic gas standards (Scotty ${ }^{\circledR} \mathrm{II}$ Analyzed Gases) were used to create a three level calibration curve for each hydrocarbon and $\mathrm{CO}_{2}$. Analytical uncertainties for these species are estimated to be $<5 \%$.

Dissolved $\mathrm{H}_{2}$ was quantitatively removed from the fluid samples by partitioning into a $\mathrm{N}_{2}$ headspace. The concentration of extracted $\mathrm{H}_{2}$ was then determined using a Shimadzu GC-8A gas chromatograph equipped with a $5 \AA$ molecular sieve packed column and a thermal conductivity detector. A $1.01 \% \mathrm{H}_{2}$ gas standard (Scotty ${ }^{\circledR} \mathrm{II}$ Analyzed Gases) was used to prepare a two level calibration. Dissolved $\mathrm{H}_{2} \mathrm{~S}$ concentrations were determined gravimetricly. Dissolved $\mathrm{H}_{2} \mathrm{~S}$ was purged from the fluid samples after acidification with $1 \mathrm{~mL}$ of $25 \% \mathrm{H}_{3} \mathrm{PO}_{4}$ and precipitated as $\mathrm{Ag}_{2} \mathrm{~S}$ in a 3 wt. $\%$ $\mathrm{AgNO}_{3}$ solution. Estimated uncertainties for both $\mathrm{H}_{2}$ and $\mathrm{H}_{2} \mathrm{~S}$ measurements are less than $5 \%$.

Dissolved organic acid anion concentrations were determined using a Dionex DX300 ion chromatograph fitted with an AS11 column and a conductivity detector. Fluid samples removed from the pipe-bomb were preserved in a $200 \mathrm{ppm}^{\mathrm{HgCl}} \mathrm{gl}_{2}$ solution, prior to analysis. Authentic standards (PolyScience Analytical Standards) were used to prepare a three level calibration curve for all organic acid anions reported. 
The absolute amounts of generated products were calculated using the following equation:

$$
\mu \mathrm{mol} / \mathrm{g} \mathrm{TOC}=\left[\left(\mathrm{V}_{\mathrm{pb}} / \mathrm{V}_{\mathrm{H} 2 \mathrm{O}}\right) \times(\mathrm{C}) /(\mathrm{M})\right] \times[100 /(\mathrm{wt} \% \% \mathrm{TOC})]
$$

where $\mathrm{V}_{\mathrm{pb}}$ is the pipe-bomb volume in $\mathrm{mL}, \mathrm{V}_{\mathrm{H} 2 \mathrm{O}}$ is the specific volume of the water at the experimental temperature and pressure in $\mathrm{mL} / \mathrm{g}, \mathrm{C}$ is the dissolved gas concentration in $\mathrm{mmol} / \mathrm{kg}$ fluid, and $\mathrm{M}$ is the mass of the starting sediment in $\mathrm{g}$. The equation of state of Haar et al. (1980) was used to calculate the specific volume of pure water.

Elemental analyses $(\mathrm{C}, \mathrm{H}, \mathrm{N}, \mathrm{S})$ were performed at the termination of each maturation experiment on the bulk sediment and kerogen fractions. Weight percent $\mathrm{O}$ was also determined for the kerogen isolates. Elemental analyses were conducted using either a Leco 932 or Fisons EA1108 elemental analyzer. Total inorganic carbonate (TIC). was determined using a UIC Inc. Coulometrics $\mathrm{CO}_{2}$ Coulometer while total organic carbon (TOC) was determined by difference.

\section{Results}

\section{Gaseous Phases}

The absolute amounts and aqueous concentrations of all gases analyzed are listed in Tables 1 and 2. As shown in Figure 2 and 3, the extent of $\mathrm{CO}_{2}$ and light hydrocarbon generation was highly dependent on temperature and time. In all experiments, $\mathrm{CO}_{2}$ was the predominant gas generated and at $360^{\circ} \mathrm{C}$ accounted for approximately 8.5 and $9.2 \%$ of the organic carbon initially present in the Monterey and Smackover shales, respectively. In addition, maturation of both shale samples led to the production of substantial amounts of $\mathrm{CO}_{2}$ at temperatures as low as $125^{\circ} \mathrm{C}$ (Tables 1,2 ). In the Monterey heating experiments, measured $\mathrm{CO}_{2}$ exhibited a steady increase with increasing temperature up to $325^{\circ} \mathrm{C}$. Duplicate experiments, MS5 and MS13, conducted at $325^{\circ} \mathrm{C}$, however, yielded $\mathrm{CO}_{2}$ values which were almost identical to the experiment at $300^{\circ} \mathrm{C}$ (Fig. 2). These depressed $\mathrm{CO}_{2}$ values were likely due to the precipitation of a carbonate containing mineral such as $\mathrm{CaCO}_{3}$ during the experiment. In experiments where calcite was not 
removed prior to heating $\left(225\right.$ and $\left.275^{\circ} \mathrm{C}\right)$ decreased production of $\mathrm{CO}_{2}$ was also observed (Table 1). This may be due to sedimentary calcite buffering fluid composition at low dissolved $\mathrm{CO}_{2}$ concentrations. Regardless, due to the possibility of calcite precipitation, the $\mathrm{CO}_{2}$ values measured during all experiments must be viewed as minimums. Duplicate heating experiments utilizing the Monterey shale (MS6 and MS9) were conducted at $360^{\circ} \mathrm{C}$ (Table 1, Fig. 2). Even though only half the amount of starting material was used in experiment MS9, the results from both experiments are in excellent agreement (Table 1, Fig. 2).

In contrast to the Monterey experiments, heating of the Smackover shale at temperatures between 150 and $325^{\circ} \mathrm{C}$ resulted in only a minor increase in $\mathrm{CO}_{2}$ production (Fig. 3). However, at $360^{\circ} \mathrm{C}$ the Smackover sample generated approximately the same amount of $\mathrm{CO}_{2}$ as the Monterey shale when normalized to organic carbon content (Tables 2 and 3). The large difference between the $\mathrm{CO}_{2}$ values measured at 325 and $360^{\circ} \mathrm{C}(62.5$ vs. $337 \mathrm{mg} / \mathrm{g}$ TOC) may reflect calcite precipitation at $325^{\circ} \mathrm{C}$. Consistent with this interpretation are higher $\mathrm{CO}_{2}$ values measured during the experiment conducted at $250^{\circ} \mathrm{C}$ as compared to $325^{\circ} \mathrm{C}$.

Measurable amounts of methane were generated from the heating of Monterey and Smackover shales at all temperatures (Tables 1 and 2). The amount of $\mathrm{CH}_{4}$ produced from maturation of the Monterey shale was an order of magnitude greater than any other hydrocarbon analyzed (Table 2). $\mathrm{CH}_{4}$ generation from the Monterey shale increased with temperature, particularly between 325 and $350^{\circ} \mathrm{C}$, where 11.1 and $25.9 \mathrm{mg} \mathrm{CH}_{4} / \mathrm{g}$ TOC were generated respectively (Fig. 2).

Comparable trends were observed in the $\mathrm{CH}_{4}$ results from the Smackover experiments (Fig. 3). However, at $360^{\circ} \mathrm{C}$ the Smackover shale produced only one third the amount of $\mathrm{CH}_{4}$ generated from the Monterey sample (12.4 vs. $31.4 \mathrm{mg} / \mathrm{g}$ TOC). $\mathrm{CH}_{4}$ was the dominant hydrocarbon produced at all temperatures, with the exception of the second sample obtained during the $125^{\circ} \mathrm{C}$ heating experiment in which propane was greater (Table 2). In addition, the Smackover shale produced over six times as much $\mathrm{CH}_{4}$ at $360^{\circ} \mathrm{C}$ compared to $325^{\circ} \mathrm{C}(12.4$ vs. $1.89 \mathrm{mg} / \mathrm{g}$ TOC). 
The combined amounts of ethylene, ethane, propylene, propane, and $n$ - and isobutane produced during heating of Monterey and Smackover shales are illustrated in Figures 2 and 3. The Monterey shale generated greater amounts of $\mathrm{C}_{2}-\mathrm{C}_{4}$ hydrocarbons at all experimental temperatures than did the Smackover sample (Figs. 2 and 3). During the Monterey experiments, the production of $\mathrm{C}_{2}-\mathrm{C}_{4}$ hydrocarbons increased dramatically between 325 and $350^{\circ} \mathrm{C}$, similar to $\mathrm{CH}_{4}$. Likewise, the amount of $\mathrm{C}_{2}-\mathrm{C}_{4}$ hydrocarbons generated from the Smackover shale at $360^{\circ} \mathrm{C}$ was roughly 5 times that produced at $325^{\circ} \mathrm{C}$ (Fig. 3). At temperatures of $200^{\circ} \mathrm{C}$ and above, alkanes were generated from both samples in greater amounts than alkenes (Tables 1 and 2). Furthermore, the difference between the amount of alkanes and alkenes produced became more pronounced with elevated temperature (Tables 1 and 2). During both the Monterey and Smackover experiments, the concentration of alkenes generally decreased with time at a given temperature (Tables 1 and 2), suggesting that they are unstable once formed. The concentrations of $n$ - and iso-butane produced from the Smackover shale were typically below detection (Table 2). In experiments with Monterey shale at $300^{\circ} \mathrm{C}$ and above, $n$ butane was generated in preference to iso-butane (Table 1).

$\mathrm{H}_{2} \mathrm{~S}$ was detected by odor from the fluid samples obtained during all Monterey shale heating experiments. Gravimetric determinations, however, were only possible in experiments conducted at $\geq 250^{\circ} \mathrm{C}$ (Table 1). $\mathrm{H}_{2} \mathrm{~S}$ was also detected in the Smackover shale fluid samples at 325 and $360^{\circ} \mathrm{C}$, yet concentrations were too low to be quantified. The amount of dissolved $\mathrm{H}_{2} \mathrm{~S}$ measured during the Monterey experiments increased with increasing temperature reaching 12.7 and $18.8 \mathrm{mg} / \mathrm{g}$ rock at 350 and $360^{\circ} \mathrm{C}$, respectively. These values exceed the amount of sulfur present as diagenetic pyrite in the initial sediment ( $10.5 \mathrm{mg} / \mathrm{g}$ sediment) indicating that organic sulfur initially present in the Monterey shale, the only other source of dissolved $\mathrm{H}_{2} \mathrm{~S}$, was released to solution (Nelson et al., 1995). Once in solution, dissolution and precipitation of metal sulfides, such as pyrite $\left(\mathrm{FeS}_{2}\right)$ and pyrrhotite (FeS), likely controlled the concentration of dissolved $\mathrm{H}_{2} \mathrm{~S}$ according to the following reactions:

$$
\mathrm{Fe}^{2+}+\mathrm{H}_{2} \mathrm{~S}=\mathrm{FeS}+2 \mathrm{H}^{+},
$$




$$
\mathrm{Fe}^{2+}+2 \mathrm{H}_{2} \mathrm{~S}+1 / 2 \mathrm{O}_{2}=\mathrm{FeS}_{2}+2 \mathrm{H}^{+}+\mathrm{H}_{2} \mathrm{O}
$$

Furthermore, the kinetics of these reactions are quite rapid under hydrothermal conditions (Seewald and Seyfried, 1990). Therefore, it is important to note that the $\mathrm{H}_{2} \mathrm{~S}$ values given in Table 1 represent absolute minimums.

Dissolved $\mathrm{H}_{2}$ concentrations were measured in the final fluid samples from the 200, 300, 325 (MS5 \& MS13) and $350^{\circ} \mathrm{C}$ Monterey shale experiments (Table 1).

Dissolved $\mathrm{H}_{2}$ concentrations were not measured during hydrous-pyrolysis of the Smackover shale. With the exception of the MS5 $-325^{\circ} \mathrm{C}$ Monterey fluid sample, the concentration of dissolved $\mathrm{H}_{2}$ increased with increasing temperature. Experiment MS5$325^{\circ} \mathrm{C}$ was the first carried out in a new pipe-bomb that was not oxidized by heating in the presence of water before use. Thus, the elevated $\mathrm{H}_{2}$ concentration observed is most likely due to oxidation of the stainless-steel walls during the experiment. In contrast, the MS13-325 ${ }^{\circ} \mathrm{C}$ experiment was the ninth heating experiment utilizing the same pipe-bomb. Accordingly, a much lower dissolved $\mathrm{H}_{2}$ concentration was observed, 0.57 vs. 1.82 mmolal for MS13-325 $\mathrm{C}$ and $\mathrm{MS} 5-325^{\circ} \mathrm{C}$, respectively.

\section{Organic Acids}

The absolute amounts of all organic acid anions analyzed are listed in Tables 3 and 4. It is likely, however, that the measured concentrations were less than what was generated during the experiments, since they represent both acid production and destruction. Continued reaction at constant temperature in the relatively high temperature experiments $\left(>225^{\circ} \mathrm{C}\right)$ may have resulted in decreasing acid concentrations, possibly due to decarboxylation reactions (Kharaka et al., 1983; Palmer and Drummond, 1986). During the Monterey hydrous-pyrolysis experiments, acetate and propionate were generated in the greatest amounts (Table 3). The observed concentrations of both acids increased with temperature and with time. Significantly lower concentrations of formate and oxalate were observed and were characterized by decreasing abundance with increasing temperature. The amount of succinate measured increased with temperature up to $300^{\circ} \mathrm{C}$, after which concentrations decreased. The abundance of valerate also increased with temperature, with concentrations typically below detection at temperatures 
less than $225^{\circ} \mathrm{C}$ (Table 3). Analysis of fluid samples obtained from experiment MS8 at $250^{\circ} \mathrm{C}$ yielded values much lower than the other experiments (Table 3 ). It is possible that these samples were not spiked with sufficient $\mathrm{HgCl}_{2}$, which could have resulted in bacterial degradation of generated acids.

Formate and acetate were the only organic acids observed in solution during all hydrous-pyrolysis experiments with the Smackover shale (Table 4). Similar to the Monterey experiments, formate was present in lesser amounts than acetate and formate abundance decreased with temperature. The greatest amount of acetate was measured in the initial fluid sample obtained at $360^{\circ} \mathrm{C}(23.8 \mathrm{mg} / \mathrm{g} \mathrm{TOC})$. However, no trend in acetate production was observed with increasing temperature (Table 4).

\section{Solid Phases}

Table 5 lists the results of the elemental analyses of the Monterey and Smackover shales and the Monterey kerogen isolates, before and after heating. The initial Monterey bulk sediment yielded a lower wt.\% TOC value (20.6 wt.\%) than was determined for the bulk sediment samples after hydrous-pyrolysis at 125 to $200^{\circ} \mathrm{C}$ (Table 5). This is likely due to the low-temperature dissolution of non-carbon containing minerals originally present in the Monterey shale, such as phosphates. Above $200^{\circ} \mathrm{C}$, wt. $\%$ TOC exhibited a steady decrease with increasing temperature as expected during hydrocarbon generation. The TOC values of the bulk sediments from experiments MS1 and MS2 $\left(225\right.$ and $\left.275^{\circ} \mathrm{C}\right)$ were relatively low since they were not acid-treated prior to heating. The percentages of $\mathrm{N}$ and $\mathrm{S}$ in the Monterey bulk sediment samples also decreased with increasing temperature.

Elemental analysis of the Monterey kerogen isolates reveals the transformations which occurred in the organic matter itself during maturation (Table 5). Wt.\% TOC increased with temperature up to $325^{\circ} \mathrm{C}$ while both wt. $\% \mathrm{H}$ and $\mathrm{O}$ decreased. Above $325^{\circ} \mathrm{C}$, the TOC values of the kerogen decreased while wt.\% O increased. Wt.\% S steadily decreased with increasing temperature from a value of $8.25 \mathrm{wt} . \%$ in the unheated kerogen to $2.73 \mathrm{wt} . \%$ at $360^{\circ} \mathrm{C}$. 
No systematic changes with increasing temperature were observed in either wt.\% TOC or N of the Smackover bulk sediments (Table 5). During hydrous-pyrolysis of the Smackover shale, the sediment is the only source of carbon available for hydrocarbon generation. The amounts of C-containing compounds generated, however, correspond to approximately $0.1 \mathrm{wt} . \% \mathrm{C}$ which is not detectable within the error of the elemental analysis.

\section{Discussion}

Petroleum generation in natural settings is traditionally described in terms of the evolution of kerogen as it is exposed to higher temperatures during burial (e.g. Tissot and Welte, 1984). In Figure 4, Tissot and Welte (1984) present a general scheme for the evolution of various kerogen types based on changes in their atomic ratios, $\mathrm{H} / \mathrm{C}$ and $\mathrm{O} / \mathrm{C}$. As burial progresses, heterotomic bonds present in the kerogen are destroyed and functional groups eliminated, producing $\mathrm{CO}_{2}$ and $\mathrm{H}_{2} \mathrm{O}$. Principal oil formation occurs after temperatures have elevated to the point that ether and $\mathrm{C}-\mathrm{C}$ bonds are cleaved in both the kerogen and bitumen. At higher temperatures, progressively more $\mathrm{C}-\mathrm{C}$ bonds are broken primarily producing methane. In natural settings, the temperature range in which oil generation has been observed is $50-150^{\circ} \mathrm{C}$ (Tissot and Welte, 1984) while the window for natural gas formation is $150-220^{\circ} \mathrm{C}$ (Quigley and Mackenzie, 1988).

The results from this study agree in many ways with the observations made by Tissot and Welte (1984). To illustrate these similarities, the variations in $\mathrm{H} / \mathrm{C}$ and $\mathrm{O} / \mathrm{C}$ of the Monterey kerogen during hydrous-pyrolysis are shown in Figure 5. In the early stages of maturation (unheated $-250^{\circ} \mathrm{C}$ ) kerogen $\mathrm{H} / \mathrm{C}$ decreased by less than $9 \%$ while $\mathrm{O} / \mathrm{C}$ dropped by over $20 \%$. This is consistent with the elimination of carboxyl, carbonyl and methoxyl functional groups from the kerogen to produce $\mathrm{CO}_{2}, \mathrm{H}_{2} \mathrm{O}$ and organic acids. As seen in Figure 2, substantial amounts of $\mathrm{CO}_{2}$ were generated at $125-250^{\circ} \mathrm{C}$. At temperatures between 275 and $325^{\circ} \mathrm{C}$, the depletion of hydrogen and oxygen from the kerogen was more extensive (Fig. 5) corresponding to an increase in the production of $\mathrm{CO}_{2}$ and in particular, light hydrocarbons (Fig. 2). In addition, Nelson et al. (1995) 
determined that peak bitumen formation from the kerogen occurred at $275^{\circ} \mathrm{C}$. At $360^{\circ} \mathrm{C}$, the removal of hydrogen from the kerogen continued, although its oxygen content increased (Fig. 5). Light hydrocarbon production increased dramatically at this temperature (Fig. 2) consistent with the decrease in H/C. In addition, light hydrocarbons were likely produced by the cracking of oil to gas as indicated by the declining saturate content of the bitumen (Nelson et al., 1995). Tissot and Welte (1984) concluded that $\mathrm{CO}_{2}$ generation occurs only at lower temperatures. Results from this study, however, clearly indicate that extensive $\mathrm{CO}_{2}$ production occurs over a wide range of hydrous-pyrolysis temperatures (Fig. 2) and is clearly not just an early maturation event.

Most hydrous-pyrolysis experiments do not produce the same distribution of $\mathrm{C}_{1}-\mathrm{C}_{4}$ hydrocarbons observed in natural gas which is typically 80 weight $\% \mathrm{CH}_{4}$ (Mango et al., 1994). Two theories have recently been postulated to explain this discrepancy. Mango et al. (1994) argue that the formation of natural gas is not simply a function of the thermal decomposition of organic matter but is aided by catalytic processes. From heating experiments combining hydrogen, $n$-alkenes and Monterey shale they obtained evidence of a catalytic pathway to natural gas. Mango et al. (1994) suggest that transition metals present in carbonaceous sedimentary rocks mediate the reaction between hydrogen and $n$ alkenes to produce light hydrocarbons.

In contrast, Price and Schoell (1995) maintain that hydrocarbon compositions measured in sedimentary basins are a function of fractionation within the reservoir and during migration from the source rock. Price and Schoell (1995) analyzed gas samples coproduced with oils directly from the Bakken shales where the local geology has prevented significant hydrocarbon migration. They discovered that weight $\% \mathrm{CH}_{4}$ in the gas samples obtained, varied from approximately $29-49 \%$. Although these results agreed with previous pyrolysis studies using the Bakken shale, the methane content is much lower than the range cited by Mango et al. (1994). Consequently, Price and Schoell (1995) argued that typical (i.e. 80 wt. $\% \mathrm{CH}_{4}$ ) hydrocarbon distributions result from physical processes occurring after hydrocarbon generation such as the preferential condensation of the $\mathrm{C}_{2}-\mathrm{C}_{4}$ gases in oil and buoyancy differences within the reservoir. 
The molecular composition of natural gas was duplicated during several of the hydrous-pyrolysis experiments conducted with the Monterey shale presented here. As seen in Figure $6 \mathrm{a}, \mathrm{CH}_{4}$ represents 80 to 90 wt. $\%$ of the $\mathrm{C}_{1}-\mathrm{C}_{4}$ hydrocarbons generated at temperatures from 125 to $250^{\circ} \mathrm{C}$. These temperatures bracket those employed by Mango et al. (1994), $190-220^{\circ} \mathrm{C}$, and include the window for natural gas generation, $150-220^{\circ} \mathrm{C}$ (Quigley and Mackenzie, 1988). These results appear consistent with those of Mango et al. (1994), however, it is questionable whether transition metals are responsible since the Monterey shale contains an abundance of sulfur which can readily quench metal activity through formation of metal sulfides. It is possible that reactions between sulfur and transition metals could prevent the catalysis of hydrogen and $n$-alkenes. Fractionation effects described by Price and Schoell (1995) could not have influenced the results of this study since a single liquid phase was maintained during our hydrous-pyrolysis experiments and there was no migration. In the case of the Monterey shale mechanisms associated with the production of gaseous products must be responsible for generating $\mathrm{C}_{1^{-}}$ $\mathrm{C}_{4}$ hydrocarbons in the same distribution as observed in sedimentary basins.

Temperature and time obviously play a role in determining the final composition of generated light hydrocarbons. Hydrous-pyrolysis of Monterey shale conducted at temperatures greater than $250^{\circ} \mathrm{C}$ resulted in a dramatic decrease in the relative amount of $\mathrm{CH}_{4}$ generated (Fig. 6a). In addition to temperature, weight $\% \mathrm{CH}_{4}$ decreased with time during each experiment (Fig. 6b). Nelson et al. (1995) established a link between organically-bound sulfur and the low temperature evolution of bitumen from Monterey shale. They argue that inherently weak polysulfide and S-C bonds present in the Monterey kerogen and generated bitumen lowers the thermal stress required for petroleum formation. The presence of sulfur had its greatest effect at temperatures below $300^{\circ} \mathrm{C}$, while at higher temperatures the cleavage of $\mathrm{C}-\mathrm{C}$ bonds became the primary mechanism of kerogen and bitumen decomposition (Nelson et al., 1995). At the point where sulfur no longer appears to be mechanistically important $\left(\mathrm{T}>300^{\circ} \mathrm{C}\right)$ weight $\%$ $\mathrm{CH}_{4}$ deviates from what is observed in natural settings (Fig. 6a). Thus, it is possible that the sulfur-rich nature of the Monterey shale may be responsible for generating $\mathrm{C}_{1}-\mathrm{C}_{4}$ 
hydrocarbons at $125-250^{\circ} \mathrm{C}$ in the same distribution as seen in nature. However, it is not clear what precursors in the kerogen would generate short-chain hydrocarbons.

Hydrous-pyrolysis of the sulfur poor, Smackover shale did not produce $\mathrm{C}_{1}-\mathrm{C}_{4}$ hydrocarbons with a 'natural' distribution. Weight $\% \mathrm{CH}_{4}$ never accounted for more than $70 \%$ of the total $\mathrm{C}_{1}-\mathrm{C}_{4}$ hydrocarbons generated from the Smackover shale (Figs. $7 \mathrm{a}$ and 7b). In contrast to the Monterey shale, wt. $\% \mathrm{CH}_{4}$ increased with increasing temperature (Fig. 7a) and time (Fig. 7b) in hydrous-pyrolysis of Smackover shale.

Recently, Tomic et al. (1995) conducted artificial maturation experiments with Monterey shale kerogen using an anhydrous closed system at temperatures ranging from 300 to $500^{\circ} \mathrm{C}$. Due to the lack of water and other experimental differences, comparisons between their results and those from this study must be made with caution. Nevertheless, a number of similarities exist between the two studies. In addition, the higher temperature range employed by Tomic et al. (1995) allows the description of hydrocarbon generation from the Monterey shale to be extrapolated to higher maturaties. In many cases the difference in experimental designs resulted in the production of disparate amounts of gases. For example, at $325^{\circ} \mathrm{C}$ and $48 \mathrm{hrs.,} \mathrm{Tomic} \mathrm{et} \mathrm{al.} \mathrm{(1995),} \mathrm{measured} \mathrm{the}$ following concentrations: $\mathrm{H}_{2} \mathrm{~S}=\sim 72 \mathrm{mg} / \mathrm{g} \mathrm{C} ; \mathrm{CO}_{2}=\sim 57 \mathrm{mg} / \mathrm{g} \mathrm{C} ; \mathrm{C}_{2}-\mathrm{C}_{4}=\sim 32 \mathrm{mg} / \mathrm{g} \mathrm{C}$; and $\mathrm{CH}_{4}=\sim 12 \mathrm{mg} / \mathrm{g} \mathrm{C}$. The hydrocarbon measurements are comparable to those observed during the $325^{\circ} \mathrm{C}$ experiments from this study (Täble 1). However, Tomic et al. (1995) observed approximately 10 times more $\mathrm{H}_{2} \mathrm{~S}$ and over $70 \%$ less $\mathrm{CO}_{2}$ than we measured. Both of these discrepancies are likely due to the presence of water in our study. First, as mentioned earlier, the dissolved $\mathrm{H}_{2} \mathrm{~S}$ concentrations analyzed represent minimums due to precipitation of metal sulfides. Second, water may act as an additional oxygen source for $\mathrm{CO}_{2}$ generation as hydrogen demand grows due to the increased production of saturated hydrocarbons with elevated temperature (Lewan, 1992).

Although the absolute amounts may differ, trends in the production of hydrocarbons and $\mathrm{CO}_{2}$ observed during this study agree with those obtained by Tomic et al. (1995). Tomic et al. (1995) observed that long-chain hydrocarbons $\left(\mathrm{C}_{14+}\right)$, the major products during early kerogen cracking, decreased rapidly from $550 \mathrm{mg} / \mathrm{g} \mathrm{C}$ at $300^{\circ} \mathrm{C}$ to close to zero at $500^{\circ} \mathrm{C}$. As a result, they concluded that primary cracking of the Monterey 
kerogen to produce bitumen must take place at temperatures below $300^{\circ} \mathrm{C}$. The results of the experiments presented here indicate maximum bitumen generation at $275^{\circ} \mathrm{C}(\mathrm{Nelson}$ et al., 1995) consistent with the results of Tomic et al. (1995). In this study, the generation of $\mathrm{CO}_{2}, \mathrm{H}_{2} \mathrm{~S}$ and hydrocarbons increased with temperature with the greatest values observed at our highest temperature, $360^{\circ} \mathrm{C}$. Tomic et al. (1995) found that the production of $\mathrm{C}_{2}-\mathrm{C}_{4}$ hydrocarbons continues to increase above $360^{\circ} \mathrm{C}$ and peaks at approximately $440^{\circ} \mathrm{C}$ followed by a rapid decline. In contrast, no decrease in $\mathrm{CH}_{4}$ generation was observed, and the generation of both $\mathrm{CO}_{2}$ and $\mathrm{H}_{2} \mathrm{~S}$ leveled off at temperatures higher than $440^{\circ} \mathrm{C}$ (Tomic et al., 1995). The continued increase in $\mathrm{CH}_{4}$ production is expected as secondary cracking of generated hydrocarbons predominates at higher temperatures (Tissot and Welte, 1984). It is possible, however, that $\mathrm{CO}_{2}$ generation may also have continued at temperatures above $440^{\circ} \mathrm{C}$ if water had been present.

The production of organic acids in sedimentary basins has been suggested to enhance porosity due to the dissolution of carbonates and aluminosilicates (Carothers and Kharaka, 1978; Schmidt and McDonald, 1979). The organic acids are likely generated from the oxidation of kerogen in the late stages of thermal maturation (Eglinton et al., 1987). Several studies utilizing hydrous-pyrolysis have shown that significant quantities of organic acids are produced during kerogen maturation (Kawamura et al., 1986; Eglinton et al., 1987; Lewan, 1993). Eglinton et al. (1993) observed that the amounts and types of acid generated varied as a function of kerogen type, maturity and mineralogy. Measurements of organic acid concentrations during the present study agree with this observation. Both the amounts and types of organic acids measured during hydrouspyrolysis of the Smackover shale were generally less than those analyzed during the Monterey shale experiments (Tables 3 and 4). In addition to the differences in kerogen type (type III versus type II-S), the greater maturity of the Smackover kerogen as compared to the Monterey kerogen likely accounts for the differences in organic acid generation observed. Unfortunately, it is difficult to assess the affect the production of organic acids had on the stability of minerals present in both shale samples. 


\section{Kinetic Modeling}

The production of light hydrocarbons and $\mathrm{CO}_{2}$ was monitored as both a function of temperature and time, allowing kinetic modeling of gas generation from the Monterey and Smackover shales. Several studies have utilized a variety of chemical kinetic models to describe the thermal maturation of kerogen to produce oil and gas (Lewan, 1985; Ungerer, 1990; Braun and Burnham, 1990; Hunt et al., 1991; Horsfield et al., 1992; Sweeney et al., 1995). These models are typically based on first order reaction kinetics and the Arrhenius equation. However, the number of chemical reactions employed to describe hydrocarbon generation varies considerably. For this study, the computer code KINETICS (Braun and Burnham, 1990) was utilized to analyze the gas data. KINETICS uses a discrete distribution model to fit an average frequency factor $\left(\mathrm{A}_{0}\right)$ and the relative fractions associated with a given activation energy $\left(E_{a}\right)$ for 25 parallel, first order reactions (Braun and Burnham, 1990). To obtain relative fractions of gases generated, the absolute amount of each gas measured at a specific temperature was normalized to the amount produced at $360^{\circ} \mathrm{C}$. A $2 \mathrm{kcal} / \mathrm{mole}$ spacing was used between consecutive values of $\mathrm{E}_{\mathrm{a}}$ for all calculations.

The modeling results for $\mathrm{CO}_{2}$ generation from the Monterey shale are shown in Figure 8. Unfortunately, because $\mathrm{CO}_{2}$ generation from the Smackover shale did not increase continuously with temperature it was not possible to accurately model using KINETICS. The Monterey shale $\mathrm{CO}_{2}$ data yielded a wide range of activation energies from 40-66 kcal/mole and a pre-exponential factor of $2.95 \times 10^{17} \mathrm{~s}^{-1}$ (Fig. 8). No more than $30 \%$ of potential $\mathrm{CO}_{2}$ production from the Monterey shale is associated with any single activation energy which suggests that a diverse set of chemical reactions are responsible for the generation of $\mathrm{CO}_{2}$.

In contrast to the $\mathrm{CO}_{2}$ modeling results, $\mathrm{CH}_{4}$ generation took place over a relatively narrow range of activation energies for both the Monterey and Smackover shale samples (Fig. 9). Primarily all of the potential $\mathrm{CH}_{4}$ generation from the Smackover shale is associated with an activation energy equal to $72 \mathrm{kcal} / \mathrm{mole}$. However, lower energy chemical reactions $\left(\mathrm{E}_{\mathrm{a}} \leq 70 \mathrm{kcal} / \mathrm{mole}\right)$ were responsible for $\mathrm{CH}_{4}$ production from the Monterey shale. Kinetic modeling of the generation of total $\mathrm{C}_{1}-\mathrm{C}_{4}$ hydrocarbons from the 
Monterey shale was also conducted, however, it was not possible for the Smackover shale since the total hydrocarbons did not increase continuously with increasing temperature (Table 2). Production of total $\mathrm{C}_{1}-\mathrm{C}_{4}$ hydrocarbons from the Monterey shale occurred between 40 and $62 \mathrm{kcal} / \mathrm{mole}$ with approximately $47 \%$ at $\mathrm{E}_{\mathrm{a}}$ equal to $62 \mathrm{kcal} / \mathrm{mole}$ (Fig. 10). This may represent the cracking of generated bitumen to produce light hydrocarbons.

The results from kinetic modeling of $\mathrm{CH}_{4}$ production from both the Monterey and Smackover shale samples were used to predict hydrocarbon generation in a hypothetical sedimentary basin shown in Figure 11. A geothermal gradient of $25^{\circ} \mathrm{C} / \mathrm{km}$ and a subsidence rate of $2 \mathrm{~km} / \mathrm{My}$ were used for this model. After $3 \mathrm{My}$, at a temperature of $170^{\circ} \mathrm{C}$, close to $20 \%$ of the $\mathrm{CH}_{4}$ generation from the Monterey shale has taken place. In contrast, the Smackover shale has produced very little at this point (Fig. 11). Around 3.5 My $\left(\sim 200^{\circ} \mathrm{C}\right)$, the generation of $\mathrm{CH}_{4}$ from both shales increases dramatically, with the two generation curves converging at $4 \mathrm{My}$ and approximately $220^{\circ} \mathrm{C}$. The differences in the gas generation curves between the Monterey and Smackover shales illustrate the effect kerogen composition and maturity have on the extent and timing of hydrocarbon generation. The generation of a significant fraction of $\mathrm{CH}_{4}$ from the Monterey shale at such an early point in its thermal history (Fig. 11) is likely due to the abundance of polysulfide bonds in the Monterey kerogen (Nelson et al., 1995). The lower thermal stress necessary to break polysulfide bonds translates to the early production of $\mathrm{CH}_{4}$ in the hypothetical basin (Fig. 11). Early $\mathrm{CH}_{4}$ may already have been produced by the Smackover shale due to its higher maturity compared to the Monterey shale. The convergence of the generation curves for each shale sample at greater depths in the basin suggests that the higher temperatures are sufficient to induce the cleavage of $\mathrm{C}-\mathrm{C}$ bonds in both the Monterey and Smackover kerogens and generated bitumen.

The kinetic modeling results of $\mathrm{CO}_{2}$ production during hydrous-pyrolysis of Monterey shale were used to predict $\mathrm{CO}_{2}$ generation in a hypothetical basin, similar to above (Fig. 12). As Tissot and Welte (1984) predict, a significant portion of $\mathrm{CO}_{2}$ generation occurred early on in the burial history of the Monterey shale. At greater depths within the basin, however, extensive $\mathrm{CO}_{2}$ production takes place (Fig. 12). 
Similar to model predictions of $\mathrm{CH}_{4}$ generation, the $\mathrm{CO}_{2}$ generation curve levels out at $220^{\circ} \mathrm{C}$. Thus, these model results provide further evidence that the generation of $\mathrm{CO}_{2}$ is not limited to lower temperatures, as suggested by Tissot and Welte (1984).

Horsfield et al. (1992) modeled the cracking of an immature crude oil to gas using closed system anhydrous-pyrolysis of a medium gravity oil from the Norwegian North Sea Central Graben. They determined that the production of $\mathrm{C}_{1}-\mathrm{C}_{4}$ hydrocarbons from the oil occurred over a relatively narrow range of activation energies, $66-70 \mathrm{kcal} / \mathrm{mol}$ with a pre-exponential factor of $1.1 \times 10^{16} \mathrm{~s}^{-1}$ (Horsfield et al., 1992). These results are in close agreement with the modeling of total hydrocarbon production from the Monterey shale (Fig. 10). During our experiments, the majority of gas production occurred at temperatures higher than maximum bitumen generation $\left(275^{\circ} \mathrm{C}\right)$. This suggests that in our study gas production was a two stage process: the decomposition of kerogen to produce bitumen and the cracking of bitumen to gas. Thus, the similarity between the kinetic modeling results of this study and those of Horsfield et al. (1992) would imply that the production of bitumen is a relatively rapid, low-temperature process. Consequently, the generation of gas from the cracking of bitumen likely governs the overall rate of gas production.

\section{Summary}

Hydrous-pyrolysis experiments utilizing the Monterey and Smackover shales were conducted at temperatures ranging from $125-360^{\circ} \mathrm{C}$ for $170 \mathrm{hrs}$ in duration. The generation of $\mathrm{CO}_{2}, \mathrm{H}_{2} \mathrm{~S}, \mathrm{H}_{2}$, light hydrocarbons $\left(\mathrm{C}_{1}-\mathrm{C}_{4}\right)$ and organic acid anions was monitored as a function of time during all experiments. In addition, changes in the elemental composition of the Monterey kerogen were determined at the end of each experiment. The production of non-hydrocarbon and hydrocarbon gases from both shale samples increased with elevated temperature. The carbon normalized amount of $\mathrm{CO}_{2}$ measured at $360^{\circ} \mathrm{C}$ was similar for both the Monterey and Smackover shales. However, over four times as much total $\mathrm{C}_{1}-\mathrm{C}_{4}$ hydrocarbons were produced from the Monterey versus Smackover shale. Weight $\% \mathrm{CH}_{4}$, normalized to total $\mathrm{C}_{1}-\mathrm{C}_{4}$ hydrocarbons, 
decreased with increasing temperature and time during hydrous-pyrolysis of Monterey shale. Kinetic models of $\mathrm{CH}_{4}$ generation yielded lower activation energies for the Monterey shale compared to the Smackover shale. The differences in the timing and extent of gas generation between the shales analyzed was attributed to the variation in kerogen type and initial maturity. The carbon- and sulfur-rich Monterey kerogen generated volatile products and organic acids in greater concentrations at lower temperatures than did the relatively organic-lean and more mature Smackover shale. The presence of abundant polysulfide linkages in the Monterey kerogen and their inherent weakness compared to C-C bonds is likely responsible for the early, low-temperature generation of volatile products and organic acids.

\section{Acknowledgments}

Thanks to M. D. Lewan (USGS, Denver, CO) for providing the Monterey Shale sample and N. L. Parmentier for elemental and organic acid anion analyses. This research was funded by U.S. Department of Energy grant \#'s DE-FGO2-86ER13466 (J. K. Whelan, J.S.S.) and DE-FGO2-92ER14232 (T.I.E.). 


\section{References}

Acholla F.V. and Orr W.L. (1993) Energy and Fuels, 7, 406-410.

Braun R.L. and Burnham A.K. (1990) KINETICS: A computer program to analyze chemical reation data. Lawerence Livermore National Laboratory Report UCID21588, Rev.1, 11 p.

Carothers W.W. and Kharaka Y.K. (1978) Aliphatic acid anions in oilfield waters Implications for origin of natural gas. Ibid. 62, 2441-2453.

Eglinton T.I., Curtis C.D. and Rowland S.J. (1987) Generation of water-soluble organic acids from kerogen during hydrous pyrolysis: implications for porosity development. Mineralogical Mag. 51, 495-503.

Eglinton T.I. and Douglas A.G. (1988) Energy and Fuels, 2, 81-88.

Haar L., Gallagher J. and Kell G. (1980) Thermodynamic properties of fluid water. In: Proceeding of the 9th International Conference on the Properties of Steam, (eds. J.Straub and K.Scheffler), Pergamon, pp. 69-82.

Harwood R.J. (1977) Oil and gas generation by laboratory pyrolysis of kerogen. AAPG Bull. 61, 2082-2102.

Horsfield B., Schenk H.J., Mills N. and Welte D.H. (1992) Closed-system programmedtemperature pyrolysis for simulating the conversion of oil to gas in a deep petroleum reservoir: Compositional and kinetic findings. Org. Geochem. 19, 191204.

Hunt J.M., Lewan M.D. and Hennet R.J-C. (1991) Modeling oil generation with timetemperature index graphs based on the Arrhenius equation. Bull. Amer. Assoc. Petrol. Geol. 75, 795-807.

Hunt J.M., Whelan J.K., Eglinton L.B. and Cathles L.M. III (1995) Relation of gas generation and shale compaction to deep overpressures in the U.S. Gulf Coast. Submitted.

Kawamura K., Tannenbaum E., Huizinga B.J. and Kaplan I.R. (1986) Volatile organic acids generated from kerogen during laboratory heating. Geochem. J. 20, 51-59.

Kharaka Y.K., Carothers W.W. and Rosenbauer R.J. (1983) Thermal decarboxylation of acetic acid: Implications for the origin of natural gas. Geochim. Cosmochim. Acta 47, 397-402.

Lewan M.D. (1985) Evalution of petroleum generation by hydrous pyrolysis experimentation. Phil. Trans. R. Soc. Lond. A315, 123-134.

Lewan M.D. (1991) Primary oil migration and expulsion by hydrous pyrolysis. Proc. 13th World Petroleum Congress, 215-223.

Lewan M.D. (1992) Water as a source of hydrogen and oxygen in petroleum fromation by hydrous pyrolysis. Am. Chem. Soc. Div. Fuel Chem. 37, 1643-1649. 
Lewan M.D. (1993) Thermal alteration of organic matter and the formation of fossil fuels: laboratory simulation of petroleum formation. In: Organic Geochemistry (Eds M.H. Engel and S.A. Macko), Plenum Press, New York.

Mango F.D., Hightower J.W. and James A.T. (1994) Catalysis in the origin of natural gas. Nature, 368, 536-538.

Nelson B.C., Eglinton T.I., Seewald J.S., Vairavamurthy A. and Miknis F.P. (1995) Transformations in organic sulfur speciation during maturation of Monterey shale: Constraints form laboratory experiments. In: Geochemical Transformations of Sedimentary Sulfur, ACS Symposium Series 612 (Eds. M.A. Vairavamurthy and M.A.A.Schoonen) pps. 138-166.

Orr W.L. (1986) Org. Geochem. 10, 499-516.

Palmer E.A. and Drummond S.E. (1986) Thermal carboxylation of acetate. Part I. The kinetics and mechanism of reaction in aqueous solution. Geochim. Cosmoschim. Acta 50, 813-823.

Price L.C., Wenger L.M., Ging T. and Blount C.W. (1983) Solubility of crude oil in methane as a function of pressure and temperature. Org. Geochem. 4, 201-221.

Price L.C. and Schoell M. (1995) Constraints on the origin of hydrocarbon gas from compositions of gases at their site of origin. Nature, 378, 368-371.

Quigley T.M. and Mackenzie A.S. (1988) Nature, 333, 549-552.

Schmidt V. and McDonald D.A. (1979) The role of secondary porosity in the course of sandstone diagenesis. SEPM Spec. Publ. 26, 175-207.

Seewald J.S. (1994) Evidence for metastable equilibrium between hydrocarbons under hydrothermal conditions. Nature, 370, 285-287.

Seewald J.S. and Seyfried W.E. Jr. (1990) Experimental determination of portlandite solubility in $\mathrm{H}_{2} \mathrm{O}$ and acetate solutions at $100-350^{\circ} \mathrm{C}$ and 500 bars: constraints on calcium hydroxide and calcium acetate complex stability. Geochim. Cosmochim. Acta, 55, 659-669.

Sweeny J.J., Talukdar S., Braun R.L., Burnham A. and Vallejos C. (1995) Chemical kinetic model of hydrocarbon generation, expulsion and destruction applied to the Maracaibo Basin, Venezuela. AAPG Bull. 79, 1515-1532.

Tannenbaum and Kaplan (1985) Low- $M_{T}$ hydrocarbons generated during hydrous and dry pryolysis of kerogen. Nature, 317, 708-709.

Tissot B.P. and Welte D.H. (1984) Petroleum Formation and Occurrance. SpringerVerlag.

Tissot B.P., Pelet R. and Ungerer P. (1987) Thermal history of sedimentary basins, maturation indicies, and kinetics of oil and gas generation. AAPG Bull. 71, 14451466. 
Tomic J., Behar F., Vandenbroucke M. and Tang Y. (1995) Artificial maturation of Monterey kerogen (Type II-S) in a closed system and comparison with Type II kerogen: implications on the fate of sulfur. Org. Geochem. 23, 647-660.

Ungerer P. (1990) State of the art research in kinetic modelling of oil formation and expulsion. Org. Geochem. 16, 1-25.

Whelan J.K., Kennicutt M.C. II, Brooks J.M., Schumacher D. and Eglinton L.B. (1994) Organic geochemical indicators of dynamic fluid flow process in petroleum basins. Org. Geochem. 22, 587-615. 
Táble 1. Absolute amounts and aqueous concentrations of selected volatile species produced during hydrous pyrolysis of carbonate-free Monterey Shale (20.6 wt. \% TOC).

\begin{tabular}{|c|c|c|c|c|c|c|c|c|c|c|c|c|}
\hline Expt. & $\begin{array}{c}\text { Time } \\
\mathrm{h}\end{array}$ & $\begin{array}{c}\text { Temp. } \\
{ }^{\circ} \mathrm{C}\end{array}$ & $\begin{array}{c}\mathrm{CO}_{2} \\
\mathrm{mg} / \mathrm{g} \mathrm{TOC} \\
\end{array}$ & $\begin{array}{c}\mathrm{CH}_{4} \\
\mathrm{mg} / \mathrm{g} \mathrm{TOC} \\
\end{array}$ & $\begin{array}{c}\mathrm{C}_{2} \mathrm{H}_{4} \\
\mu \mathrm{g} / \mathrm{g} \mathrm{TOC}\end{array}$ & $\begin{array}{c}\mathrm{C}_{2} \mathrm{H}_{6} \\
\mu \mathrm{g} / \mathrm{g} \text { TOC } \\
\end{array}$ & $\begin{array}{c}\mathrm{C}_{3} \mathrm{H}_{6} \\
\mu \mathrm{g} / \mathrm{g} \text { TOC }\end{array}$ & $\begin{array}{c}\mathrm{C}_{3} \mathrm{H}_{8} \\
\mu \mathrm{g} / \mathrm{g} \text { TOC }\end{array}$ & $\begin{array}{l}n-\mathrm{C}_{4} \mathrm{H}_{10} \\
\mu \mathrm{g} / \mathrm{g} \text { TOC }\end{array}$ & $\begin{array}{l}i-\mathrm{C}_{4} \mathrm{H}_{10} \\
\mu \mathrm{g} / \mathrm{g} \text { TOC }\end{array}$ & $\begin{array}{c}\mathrm{H}_{2} \mathrm{~S} \\
\mu \mathrm{g} / \mathrm{g} \text { rock }\end{array}$ & $\begin{array}{c}\mathrm{H}_{2} \\
\text { mmolal }\end{array}$ \\
\hline \multirow[t]{2}{*}{ MS4 } & 50.9 & 125 & 16.1 & 0.0022 & 0.243 & 0.146 & 0.485 & 0.097 & bd & bd & - & - \\
\hline & 173.2 & 125 & 29.2 & 0.0058 & 0.194 & 0.437 & 0.631 & 0.194 & bd & bd & - & - \\
\hline \multirow[t]{3}{*}{ MS 10} & 26.3 & 151 & 31.1 & 0.0098 & 0.680 & 0.874 & 2.18 & 0.388 & bd & bd & - & - \\
\hline & 71.0 & 150 & 38.3 & 0.0170 & 0.583 & 1.60 & 1.80 & 0.680 & bd & bd & - & - \\
\hline & 167.3 & 150 & 42.1 & 0.0248 & 0.583 & 2.38 & 1.46 & 1.12 & bd & bd & - & - \\
\hline \multirow[t]{3}{*}{ MS3 } & 24.4 & 174 & 40.6 & 0.0297 & 1.41 & 2.09 & 2.82 & 1.12 & 0.194 & 0.194 & - & - \\
\hline & 72.4 & 174 & 53.9 & 0.0583 & 1.80 & 4.27 & 3.35 & 2.43 & 0.388 & 0.291 & - & - \\
\hline & 167.6 & 174 & 64.6 & 0.0937 & 2.18 & 6.41 & 4.17 & 3.79 & 0.728 & 2.14 & - & - \\
\hline \multirow[t]{2}{*}{ MS14 } & 51.4 & 196 & 95.6 & 0.225 & 5.39 & 16.3 & 8.69 & 10.1 & bd & bd & - & - \\
\hline & 169.3 & 196 & 100 & 0.366 & 5.73 & 28.5 & 10.8 & 18.9 & bd & bd & - & 0.0056 \\
\hline \multirow[t]{3}{*}{$\mathrm{MSI}^{\dagger}$} & 21.3 & 225 & 88.8 & 0.374 & 23.8 & 35.8 & 37.1 & 21.5 & 4.51 & 3.93 & - & - \\
\hline & 71.7 & 224 & 98.1 & 0.529 & 20.6 & 55.8 & 36.6 & 33.3 & 7.38 & 8.30 & - & - \\
\hline & 167.3 & 224 & 105 & 0.718 & 20.3 & 82.0 & 33.6 & 50.0 & 12.0 & 13.0 & & - \\
\hline \multirow[t]{3}{*}{ MS8 } & 23.3 & 247 & 111 & 0.893 & 40.3 & 104 & 43.0 & 63.1 & bd & bd & 3.80 & - \\
\hline & 69.9 & 248 & 128 & 1.26 & 40.0 & 185 & 51.9 & 112 & bd & bd & - & - \\
\hline & 165.3 & 248 & 143 & 1.50 & 36.8 & 263 & 52.4 & 156 & bd & bd & 6.86 & - \\
\hline \multirow[t]{3}{*}{$\mathrm{MS}^{\dagger}$} & 22.5 & 275 & 91.7 & 1.35 & 66.5 & 332 & 87.9 & 412 & 62.1 & 57.8 & - & - \\
\hline & 70.3 & 274 & 117 & 2.25 & 48.0 & 704 & 85.4 & 874 & 172 & 170 & - & - \\
\hline & 164.8 & 274 & 125 & 2.90 & 42.0 & 1063 & 144 & 777 & 340 & 301 & - & - \\
\hline \multirow[t]{3}{*}{ MS11 } & 24.3 & 300 & 182 & 3.42 & 110 & 1539 & 216 & 869 & 675 & 485 & 8.06 & - \\
\hline & 71.9 & 300 & 203 & 5.19 & 82.5 & 2811 & 220 & 1684 & 1218 & 840 & 7.94 & - \\
\hline & 168.3 & 299 & 219 & 6.50 & 78.2 & 4087 & 213 & 2558 & 1733 & 1092 & 8.38 & 0.43 \\
\hline \multirow[t]{3}{*}{ MS5 } & 24.1 & 323 & 167 & 5.29 & 154 & 3141 & 314 & - & 1228 & 850 & - & - \\
\hline & 70.8 & 324 & 171 & 6.94 & 53.9 & 5340 & - & - & 2131 & 1194 & - & - \\
\hline & 168.0 & 324 & 217 & 10.0 & 68.4 & 8447 & 733 & - & 3689 & 1728 & - & 1.82 \\
\hline \multirow[t]{3}{*}{ MS13 } & 26.7 & 323 & 191 & 7.28 & 123 & 4811 & 299 & 3087 & 1981 & 1117 & 7.62 & - \\
\hline & 70.8 & 324 & 196 & 8.59 & 93.7 & 6311 & 295 & 4102 & 2573 & 1413 & 7.86 & - \\
\hline & 168.8 & 322 & 219 & 11.1 & 78.2 & 8204 & 277 & 5388 & 3320 & 1777 & 9.26 & 0.57 \\
\hline \multirow[t]{3}{*}{ MS12 } & 24.7 & 350 & 228 & 15.1 & 154 & 10631 & 568 & 6408 & 3888 & 2432 & 13.5 & - \\
\hline & 74.9 & 350 & 260 & 21.4 & 101 & 15291 & 650 & 9515 & 5631 & 3301 & 14.4 & - \\
\hline & 145.0 & 350 & 280 & 25.9 & 87.4 & 18155 & 390 & 11505 & 6748 & 3811 & 12.7 & 0.77 \\
\hline \multirow[t]{3}{*}{ MS6 } & 24.4 & 359 & - & 16.2 & 25.2 & 10728 & 447 & 6553 & 4218 & 2660 & - & - \\
\hline & 71.8 & 360 & - & 25.7 & 63.6 & 17087 & 412 & 11068 & 7136 & 4209 & - & - \\
\hline & 172.3 & 360 & 300 & 30.4 & 52.9 & 20534 & 360 & 13932 & 8350 & 4845 & - & - \\
\hline \multirow[t]{3}{*}{ MS9 } & 23.2 & 359 & 253 & 17.4 & 293 & 11699 & 942 & 6942 & 4903 & 2927 & 13.9 & - \\
\hline & 72.2 & 359 & 285 & 24.7 & 206 & 16699 & 791 & - & 7282 & 4058 & 14.2 & - \\
\hline & 169.0 & 358 & 312 & 31.4 & 181 & 20631 & 718 & 10971 & 8981 & 4762 & 18.8 & - \\
\hline
\end{tabular}

${ }^{\dagger}$ Sedimentary carbonate was not removed from the intial sediment

-: not analyzed

bd: below detection 
Table 2. Absolute amounts and aqueous concentrations of selected volatile species produced during hydrous-pyrolysis of carbonate-free Smackover Shale (0.92 wt. \% TOC).

\begin{tabular}{|c|c|c|c|c|c|c|c|c|c|c|}
\hline Expt. & $\begin{array}{c}\text { Time } \\
\mathrm{h}\end{array}$ & $\begin{array}{c}\text { Temp. } \\
{ }^{\circ} \mathrm{C} \\
\end{array}$ & $\begin{array}{c}\mathrm{CO}_{2} \\
\mathrm{mg} / \mathrm{g} \text { TOC }\end{array}$ & $\begin{array}{c}\mathrm{CH}_{4} \\
\mathrm{mg} / \mathrm{g} \text { TOC }\end{array}$ & $\begin{array}{c}\mathrm{C}_{2} \mathrm{H}_{4} \\
\mu \mathrm{g} / \mathrm{g} \text { TOC }\end{array}$ & $\begin{array}{c}\mathrm{C}_{2} \mathrm{H}_{6} \\
\mu \mathrm{g} / \mathrm{g} \text { TOC }\end{array}$ & $\begin{array}{c}\mathrm{C}_{3} \mathrm{H}_{6} \\
\mu \mathrm{g} / \mathrm{g} \text { TOC }\end{array}$ & $\begin{array}{c}\mathrm{C}_{3} \mathrm{H}_{8} \\
\mu \mathrm{g} / \mathrm{g} \text { TOC }\end{array}$ & $\begin{array}{l}n-\mathrm{C}_{4} \mathrm{H}_{10} \\
\mu \mathrm{g} / \mathrm{g} \text { TOC }\end{array}$ & $\begin{array}{l}i-\mathrm{C}_{4} \mathrm{H}_{10} \\
\mu \mathrm{g} / \mathrm{g} \text { TOC }\end{array}$ \\
\hline \multirow[t]{2}{*}{ SM2 } & 51.0 & 125 & 5.02 & 0.0046 & 0.763 & 0.872 & 0.436 & 3.71 & bd & bd \\
\hline & 171.3 & 125 & 9.92 & 0.0055 & 0.545 & 1.31 & 0.545 & 6.65 & bd & bd \\
\hline \multirow[t]{3}{*}{ SM6 } & 26.5 & 151 & 27.5 & 0.0095 & bd & 8.07 & bd & 8.62 & bd & $\mathrm{bd}$ \\
\hline & 71.2 & 150 & 30.9 & 0.0100 & bd & 7.74 & bd & 8.29 & bd & $\mathrm{bd}$ \\
\hline & 167.2 & 150 & 35.7 & 0.0115 & bd & 8.51 & $\mathrm{bd}$ & 9.60 & bd & bd \\
\hline \multirow[t]{3}{*}{ SM1 } & 24.3 & 174 & 23.6 & 0.0093 & 1.85 & 1.64 & 1.85 & 4.14 & 3.60 & 0.763 \\
\hline & 72.3 & 174 & 30.9 & 0.0115 & 2.29 & 2.18 & 2.29 & 4.47 & 4.47 & bd \\
\hline & 167.4 & 174 & 34.7 & 0.0123 & 2.07 & 2.07 & 2.40 & 4.58 & 4.80 & bd \\
\hline \multirow[t]{3}{*}{ SM4 } & 23.6 & 247 & 46.3 & 0.0662 & 9.41 & 25.8 & 7.31 & 27.9 & bd & bd \\
\hline & 70.1 & 248 & 54.1 & 0.157 & 12.8 & 41.7 & 7.20 & 32.1 & bd & bd \\
\hline & 165.4 & 248 & 63.5 & 0.252 & 16.6 & 81.4 & 8.18 & 47.7 & bd & bd \\
\hline \multirow[t]{3}{*}{ SM3 } & 25.4 & 323 & 43.3 & 0.815 & 132 & 353 & 140 & 282 & bd & bd \\
\hline & 69.7 & 324 & 48.5 & 1.46 & 169 & 725 & 184 & 497 & bd & bd \\
\hline & 170.8 & 324 & 62.5 & 1.89 & 111 & 607 & 150 & 409 & bd & bd \\
\hline \multirow[t]{3}{*}{ SM5 } & 23.4 & 359 & 219 & 6.66 & 254 & 2388 & 678 & 1625 & bd & bd \\
\hline & 72.3 & 359 & 278 & 9.69 & 141 & 3555 & 471 & - & bd & bd \\
\hline & 168.8 & 358 & 337 & 12.4 & 113 & 4231 & 338 & 658 & 1265 & 379 \\
\hline
\end{tabular}

-: not analyzed

bd: below detection 
Table 3. Absolute amounts of organic acid anions during hydrous pyrolysis of Monterey Shale.

\begin{tabular}{|c|c|c|c|c|c|c|c|c|}
\hline Expt. & $\begin{array}{l}\text { Time } \\
\text { (h) }\end{array}$ & $\begin{array}{c}\text { Temp. } \\
\left({ }^{\circ} \mathrm{C}\right)\end{array}$ & Formate & Aceta & $\begin{array}{l}\text { Propionate } \\
\text { (mg / g TO }\end{array}$ & $\begin{array}{l}\text { Valer } \\
\text { C) }\end{array}$ & Oxalate & Suc \\
\hline \multirow[t]{2}{*}{ MS4 } & 50.9 & 125 & 2.49 & 2.63 & 0.143 & bd & 2.94 & 0.262 \\
\hline & 173.2 & 125 & 2.53 & 2.87 & 0.185 & 0.679 & 2.79 & 0.271 \\
\hline \multirow[t]{3}{*}{ MS10 } & 26.3 & 151 & 2.00 & 2.91 & 0.209 & bd & 4.65 & 0.438 \\
\hline & 71.0 & 150 & 1.81 & 3.70 & 0.263 & bd & 4.83 & 0.496 \\
\hline & 167.3 & 150 & 1.52 & 8.23 & 1.69 & 0.136 & 3.10 & 1.04 \\
\hline \multirow[t]{3}{*}{ MS3 } & 24.4 & 174 & 1.52 & 4.11 & 0.271 & 0.924 & 2.26 & 0.452 \\
\hline & 72.4 & 174 & 1.98 & 4.15 & 0.360 & bd & 1.73 & 0.476 \\
\hline & 167.6 & 174 & 1.96 & 5.54 & 0.479 & bd & 1.03 & 0.549 \\
\hline \multirow[t]{2}{*}{ MS14 } & 51.4 & 196 & bd & 6.23 & 0.719 & bd & 0.699 & bd \\
\hline & 169.3 & 196 & bd & 7.37 & 0.879 & bd & 0.809 & bd \\
\hline \multirow[t]{3}{*}{$\mathrm{MS}^{\dagger}$} & 21.3 & 225 & 4.06 & 8.40 & 0.903 & bd & 0.265 & 0.831 \\
\hline & 71.7 & 224 & 1.62 & 10.4 & 1.26 & bd & bd & bd \\
\hline & 167.3 & 224 & 0.876 & 11.3 & 1.41 & bd & bd & 0.934 \\
\hline \multirow[t]{3}{*}{ MS8 } & 23.3 & 247 & bd & 0.162 & 0.029 & bd & bd & 0.066 \\
\hline & 69.9 & 248 & 0.007 & 0.296 & 0.123 & bd & 0.036 & 0.087 \\
\hline & 165.3 & 248 & bd & 0.164 & 0.074 & bd & bd & 0.077 \\
\hline \multirow[t]{3}{*}{$\mathrm{MS}^{\dagger}$} & 22.5 & 275 & 0.227 & 20.6 & 3.26 & 0.271 & bd & 4.57 \\
\hline & 70.3 & 274 & 0.732 & 23.5 & 3.93 & bd & bd & 1.74 \\
\hline & 164.8 & 274 & 0.639 & 26.1 & 4.86 & 0.106 & bd & 1.58 \\
\hline \multirow[t]{3}{*}{ MS11 } & 24.3 & 300 & 0.417 & 12.5 & 3.72 & 0.269 & 0.105 & 1.41 \\
\hline & 71.9 & 300 & 0.467 & 20.0 & 4.74 & 0.414 & bd & 1.35 \\
\hline & 168.3 & 299 & 0.200 & 13.3 & 2.70 & bd & bd & 0.330 \\
\hline \multirow[t]{3}{*}{ MS5 } & 24.1 & 323 & 0.926 & 26.4 & 6.56 & 0.483 & 0.111 & 1.110 \\
\hline & 70.8 & 324 & 0.896 & 25.2 & 6.62 & 0.539 & bd & 0.655 \\
\hline & 168.0 & 324 & 0.965 & 30.2 & 8.32 & 0.546 & bd & bd \\
\hline \multirow[t]{3}{*}{ MS13 } & 26.7 & 323 & bd & 16.8 & 4.72 & 0.524 & 0.524 & bd \\
\hline & 70.8 & 324 & bd & 19.2 & 5.54 & 0.602 & 0.294 & bd \\
\hline & 168.8 & 322 & bd & 21.1 & 6.08 & 0.529 & bd & bd \\
\hline \multirow[t]{3}{*}{ MS12 } & 24.7 & 350 & bd & 25.7 & 6.90 & 0.716 & 0.368 & bd \\
\hline & 74.9 & 350 & bd & 28.0 & 7.64 & 0.781 & bd & bd \\
\hline & 145.0 & 350 & bd & 28.6 & 7.73 & 0.611 & bd & bd \\
\hline \multirow[t]{3}{*}{ MS9 } & 23.2 & 359 & 0.825 & 22.0 & 6.54 & 0.614 & 0.055 & 0.174 \\
\hline & 72.2 & 359 & 1.03 & 28.1 & 8.06 & 0.789 & bd & bd \\
\hline & 169.0 & 358 & 0.278 & 12.6 & bd & bd & bd & bd \\
\hline
\end{tabular}

${ }^{\dagger}$ Sedimentary carbonate was not removed from the intial sediment bd: below detection 
Table 4. Absolute amounts of organic acid anions during hydrous pyrolysis of Smackover Shale.

\begin{tabular}{lrrrrrrrr}
\hline Expt. & $\begin{array}{c}\text { Time } \\
\text { (h) }\end{array}$ & $\begin{array}{c}\text { Temp. Formate } \\
\left({ }^{\circ} \mathrm{C}\right)\end{array}$ & \multicolumn{7}{c}{ Acetate Propionate Valerate } & Oxalate Succinate \\
SM2 & 51.0 & 125 & 2.09 & 9.24 & bd & bd & bd & bd \\
& 171.3 & 125 & 11.3 & 6.23 & bd & bd & bd & bd \\
SM6 & 26.5 & 151 & 2.76 & 7.44 & bd & bd & 3.78 & bd \\
& 71.2 & 150 & 2.91 & 6.66 & bd & bd & 4.84 & bd \\
& 167.2 & 150 & 2.63 & 6.18 & bd & bd & 4.84 & bd \\
SM1 & 24.3 & 174 & 2.97 & 12.1 & bd & bd & 1.94 & bd \\
& 72.3 & 174 & 8.97 & 63.4 & bd & bd & bd & bd \\
& 167.4 & 174 & 3.66 & 8.32 & bd & bd & bd & bd \\
SM4 & 23.6 & 247 & 0.99 & 6.98 & bd & bd & bd & bd \\
& 70.1 & 248 & 1.14 & 9.83 & bd & bd & bd & bd \\
& 165.4 & 248 & 0.65 & 8.98 & bd & bd & bd & bd \\
SM3 & 25.4 & 323 & 0.43 & 4.44 & bd & bd & bd & bd \\
& 69.7 & 324 & 0.68 & 5.29 & bd & bd & bd & bd \\
& 170.8 & 324 & bd & bd & bd & bd & bd & bd \\
SM5 & 23.4 & 359 & 0.57 & 23.8 & bd & bd & bd & bd \\
& 72.3 & 359 & 0.28 & 8.43 & bd & bd & bd & bd \\
& 168.8 & 358 & 0.34 & 9.02 & bd & bd & bd & bd \\
\hline
\end{tabular}

bd: below detection 
Table 5. Elemental compostion of bulk sediments and kerogens from hydrous pyrolysis experiments.

\begin{tabular}{|c|c|c|c|c|c|c|c|}
\hline Experiment & $\begin{array}{c}\text { Sample } \\
\text { Type }\end{array}$ & $\begin{array}{l}\text { Temp. } \\
\left({ }^{\circ} \mathrm{C}\right)\end{array}$ & TOC & $\begin{array}{l}\mathrm{H} \\
\text { (v }\end{array}$ & $\begin{array}{c}\mathrm{N} \\
\text { veight } \%\end{array}$ & (0) & $\mathrm{O}$ \\
\hline Init. Monterey & Bulk Sed. & 25 & 20.6 & - & 1.24 & 3.86 & - \\
\hline MS4 & " & 125 & 22.6 & - & 1.36 & 3.67 & - \\
\hline MS 10 & $"$ & 150 & 23.5 & - & 1.42 & 3.67 & - \\
\hline MS3 & $"$ & 175 & 22.4 & - & 1.34 & 3.50 & - \\
\hline MS14 & $"$ & 200 & 22.6 & - & 1.23 & 3.02 & - \\
\hline MS1 & $"$ & 225 & 18.6 & - & 1.08 & 2.64 & - \\
\hline MS8 & $"$ & 250 & 20.3 & - & 1.21 & 3.06 & - \\
\hline MS2 & $"$ & 275 & 15.6 & - & 0.94 & 2.36 & - \\
\hline MS11 & " & 300 & 18.3 & - & 1.12 & 2.24 & - \\
\hline MS5 & $"$ & 325 & - & - & - & - & - \\
\hline MS13 & $"$ & 325 & 16.7 & - & 0.97 & 2.21 & - \\
\hline MS12 & $"$ & 350 & 15.1 & - & 0.90 & 1.81 & - \\
\hline MS6 & $"$ & 360 & 14.1 & - & 0.94 & 1.87 & - \\
\hline MS9 & " & 360 & 15.3 & - & 1.04 & 1.33 & - \\
\hline Init. Monterey & Kerogen & 25 & 60.4 & 6.52 & 3.22 & 8.25 & 17.5 \\
\hline MS4 & " & 125 & 59.8 & 6.41 & 3.06 & 7.83 & 17.5 \\
\hline MS10 & $"$ & 150 & 59.6 & 6.86 & 2.91 & 7.50 & 16.3 \\
\hline MS3 & $"$ & 175 & 60.8 & 6.22 & 3.11 & 7.39 & 17.1 \\
\hline MS14 & $"$ & 200 & 64.6 & 6.45 & 3.14 & 6.92 & 14.6 \\
\hline MS1 & $"$ & 225 & 62.9 & 6.28 & 3.24 & 6.04 & 15.5 \\
\hline MS8 & $"$ & 250 & 60.8 & 5.99 & 2.93 & 5.21 & 14.0 \\
\hline MS2 & $"$ & 275 & 69.1 & 5.74 & 3.60 & 4.49 & 11.7 \\
\hline MS11 & $"$ & 300 & 72.6 & 5.66 & 3.70 & 3.91 & 8.9 \\
\hline MS5 & $"$ & 325 & - & - & - & - & - \\
\hline MS13 & $"$ & 325 & 75.3 & 5.03 & 3.95 & 3.40 & 8.5 \\
\hline MS12 & $"$ & 350 & 65.2 & 4.39 & 3.54 & 2.94 & - \\
\hline MS6 & $"$ & 360 & 64.8 & 3.98 & 3.67 & 2.73 & 10.3 \\
\hline MS9 & $"$ & 360 & - & - & - & - & 11.1 \\
\hline Init. Smackover & Bulk Sed. & 25 & 0.92 & - & 0.037 & - & - \\
\hline SM2 & " & 125 & 0.90 & - & 0.067 & - & - \\
\hline SM6 & $"$ & 150 & 1.67 & - & 0.086 & - & - \\
\hline SM1 & $"$ & 175 & 0.94 & - & 0.062 & - & - \\
\hline SM4 & $"$ & 250 & $1.16^{\circ}$ & - & 0.066 & - & - \\
\hline SM3 & $"$ & 325 & 0.79 & - & 0.059 & - & - \\
\hline SM5 & $"$ & 360 & 0.95 & - & 0.069 & - & - \\
\hline
\end{tabular}

-: not analyzed 


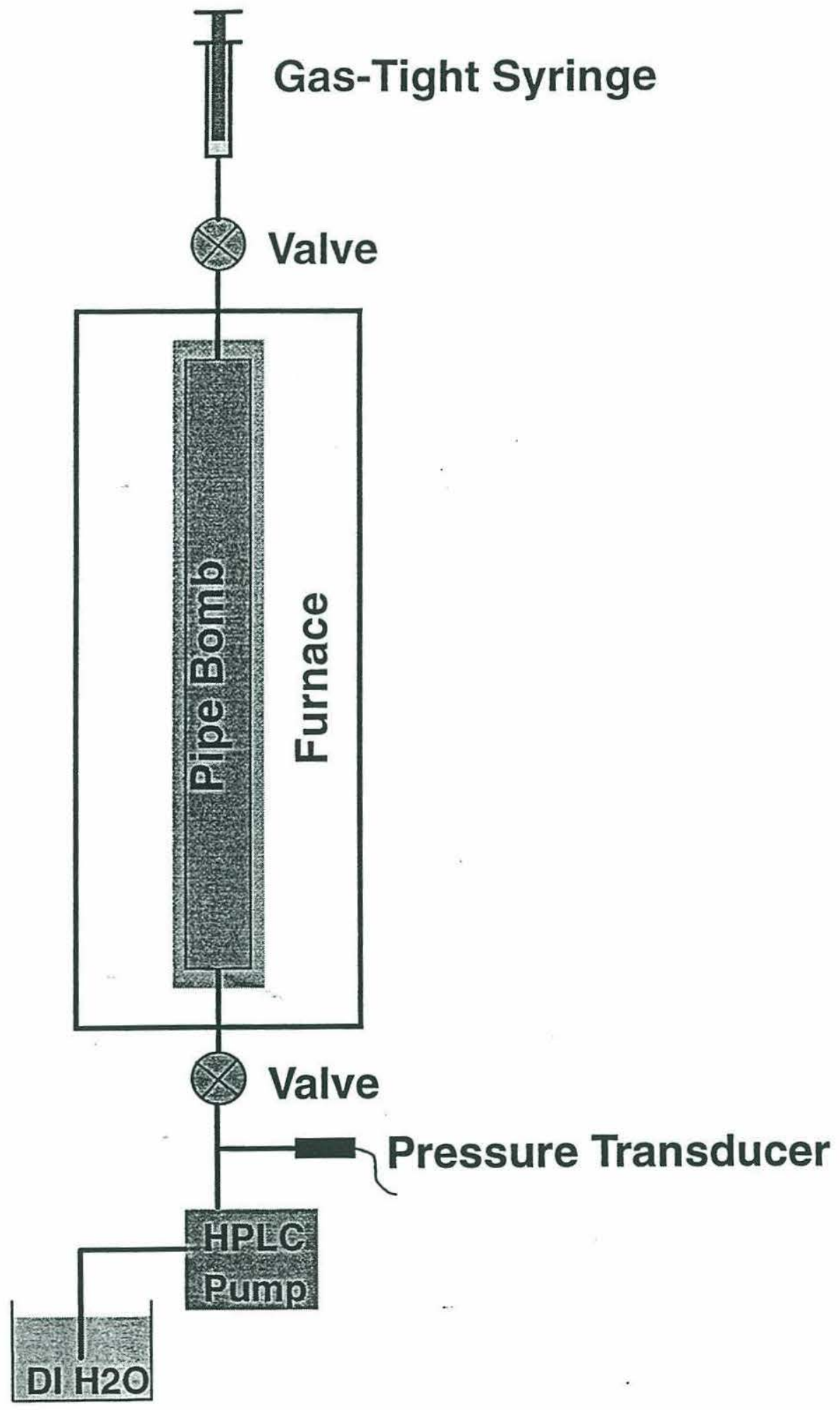

Figure 1. Hydrous-pyrolysis reaction vessel, furnace, sampling valves, HPLC pump and pressure monitor. 

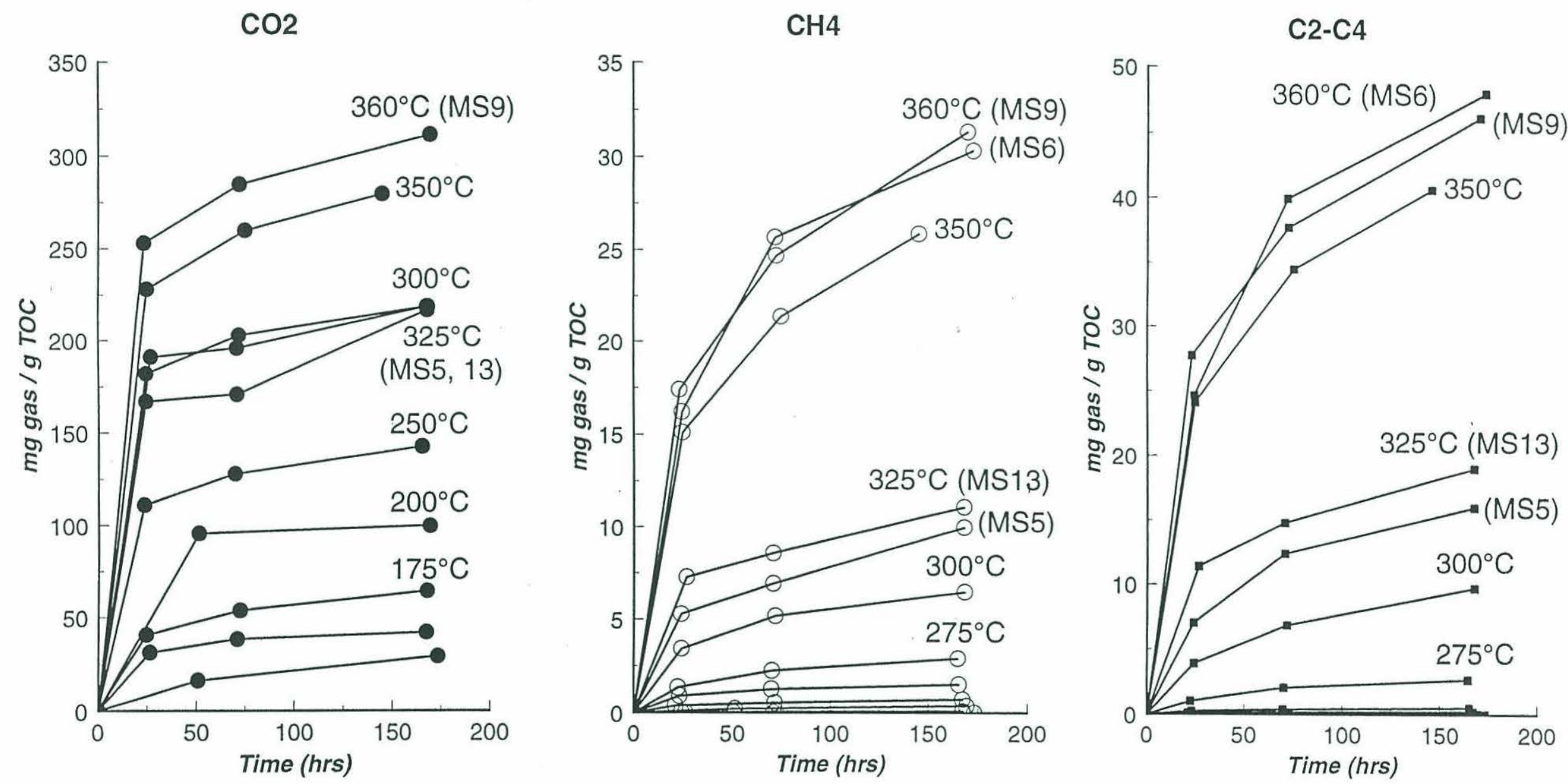

Figure 2. Gas generation curves for (a) $\mathrm{CO}_{2}$, (b) $\mathrm{CH}_{4}$ and (c) $\mathrm{C}_{2}-\mathrm{C}_{4}$ hydrocarbons from hydrous-pyrolysis of Monterey shale. 

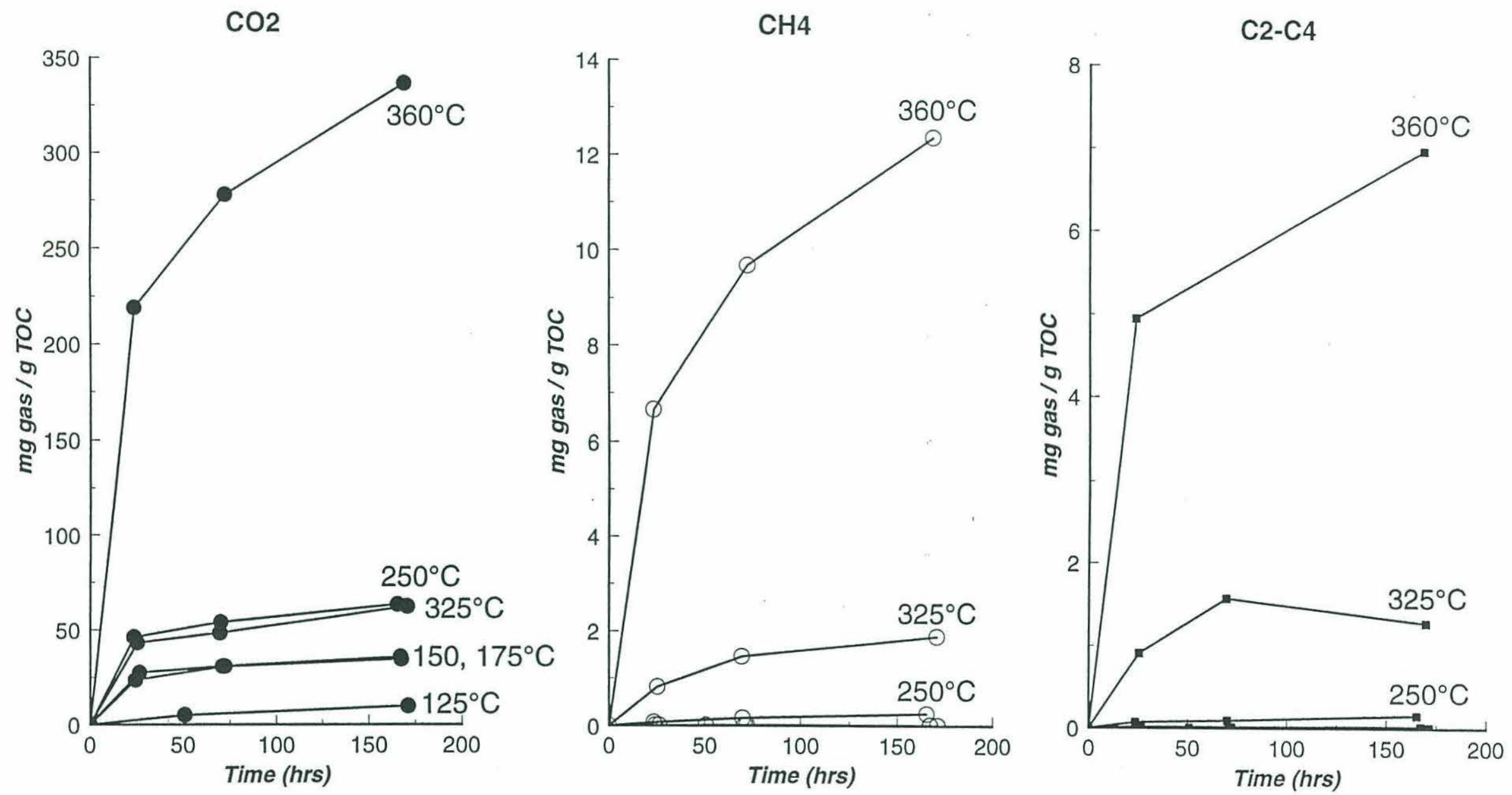

Figure 3. Gas generation curves for (a) $\mathrm{CO}_{2}$, (b) $\mathrm{CH}_{4}$ and (c) $\mathrm{C}_{2}-\mathrm{C}_{4}$ hydrocarbons from hydrous-pyrolysis of Smackover shale. 


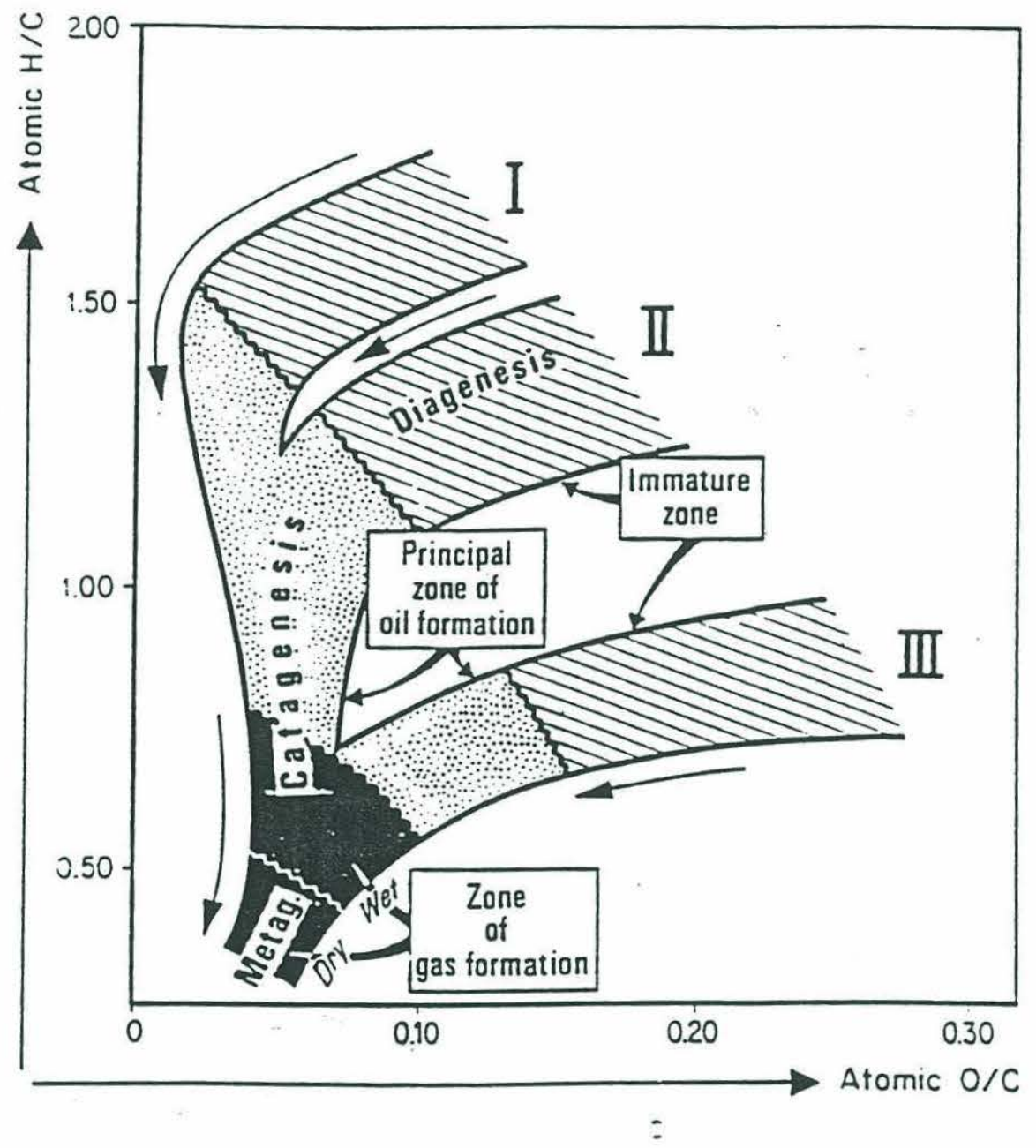

Principal products of kerogen evolution

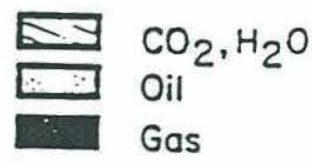

Figure 4. Van Krevlen plot modeling kerogen maturation and the generation of liquid and volatile products, from Tissot and Welte (1984). 


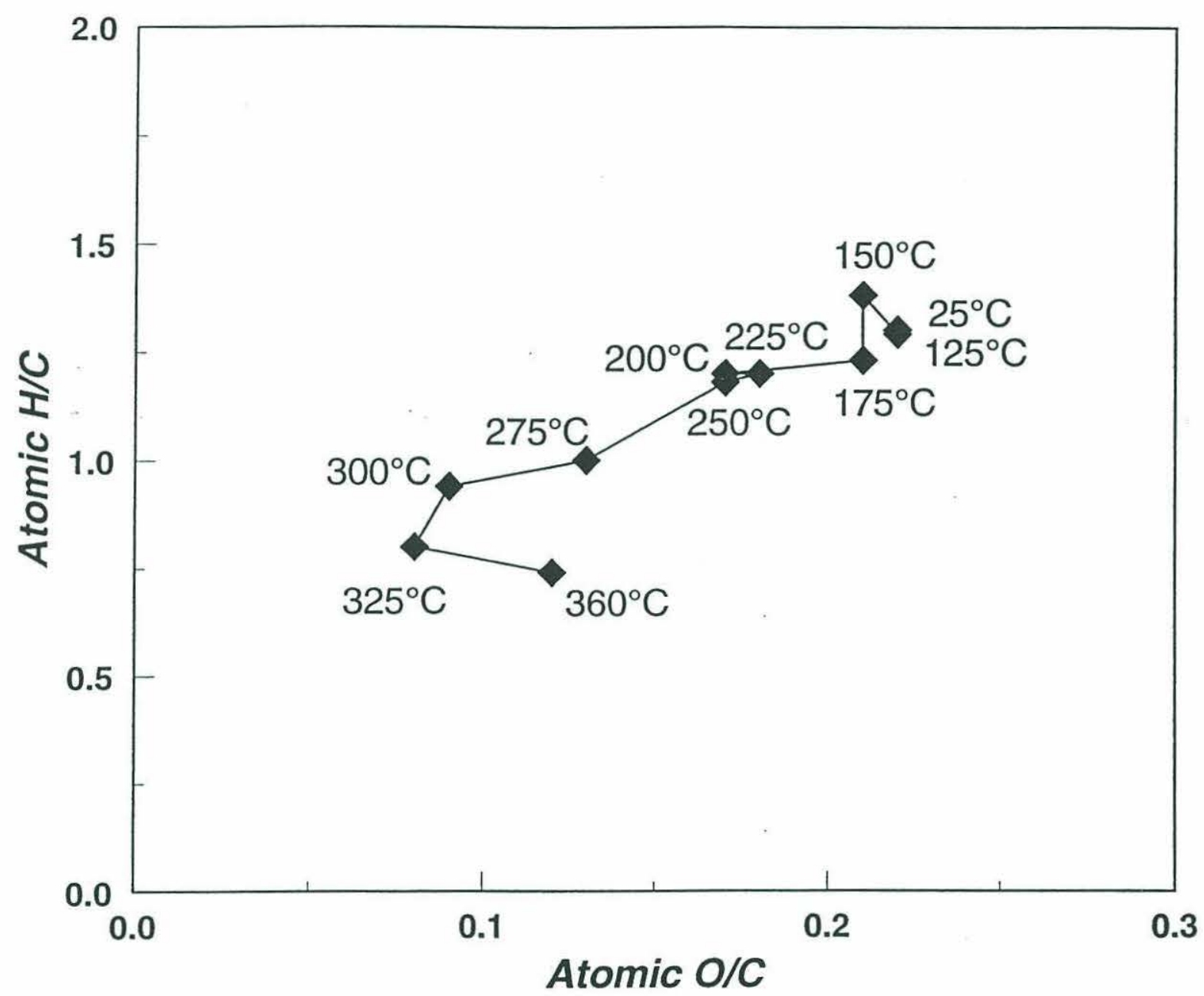

Figure 5. Van Krevlen plot of Monterey shale kerogens after hydrous-pyrolysis at the temperature shown next to each data point. 

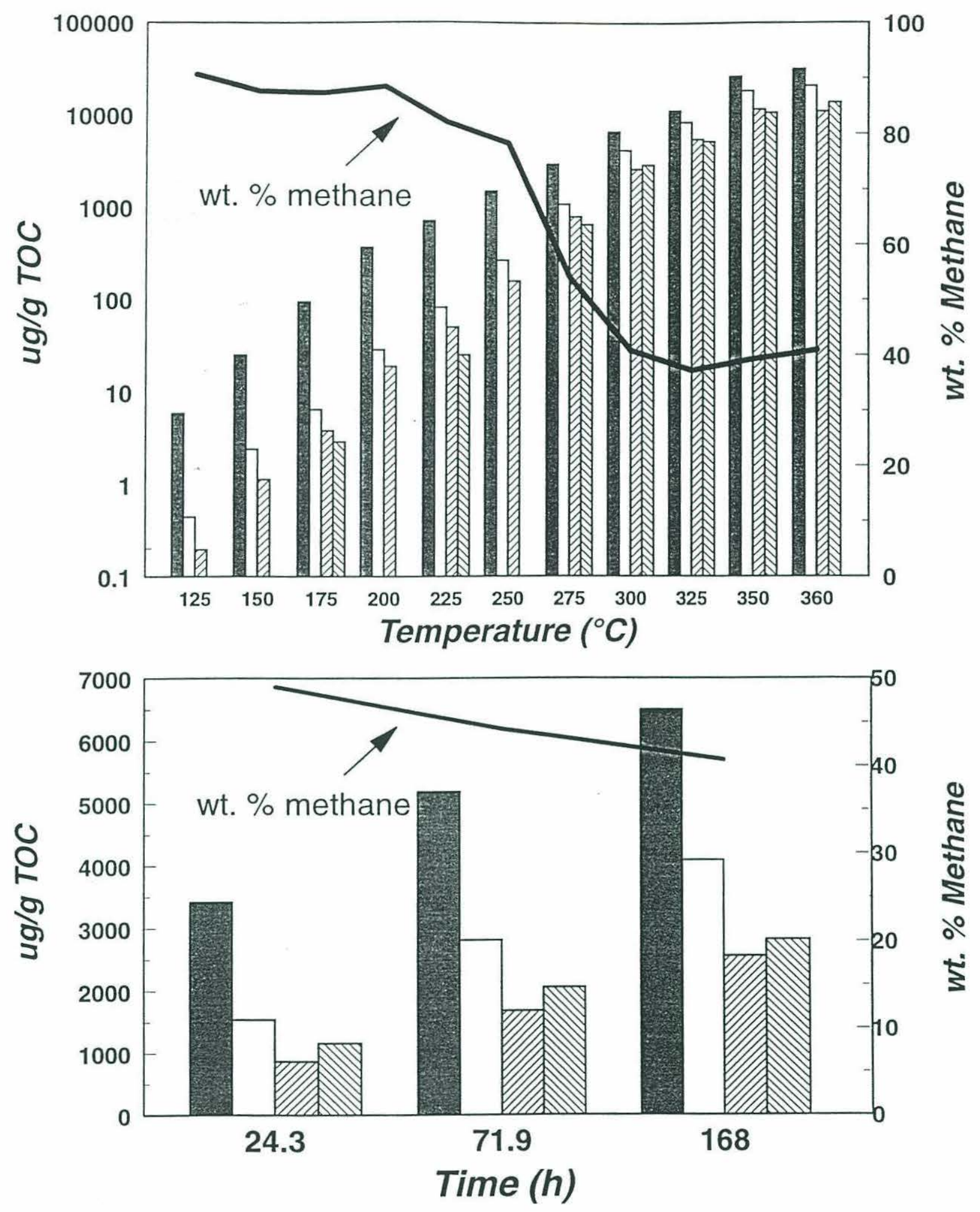

Methane Ethane Propane Butane

Figure 6. (a) Log amounts of $\mathrm{CH}_{4}, \mathrm{C}_{2} \mathrm{H}_{6}, \mathrm{C}_{3} \mathrm{H}_{8}$, and iso- $+n$ - $\mathrm{C}_{4} \mathrm{H}_{10}$ hydrocarbons generated from hydrous-pyrolysis of Monterey shale at all experimental temperatures versus wt. \% $\mathrm{CH}_{4}$. (b) Amounts of $\mathrm{CH}_{4}, \mathrm{C}_{2} \mathrm{H}_{6}, \mathrm{C}_{3} \mathrm{H}_{8}$, and iso- $+n$ $\mathrm{C}_{4} \mathrm{H}_{10}$ hydrocarbons generated during the $300^{\circ} \mathrm{C}$ Monterey shale hydrous-pyrolysis experiment versus wt. \% $\mathrm{CH}_{4}$. 

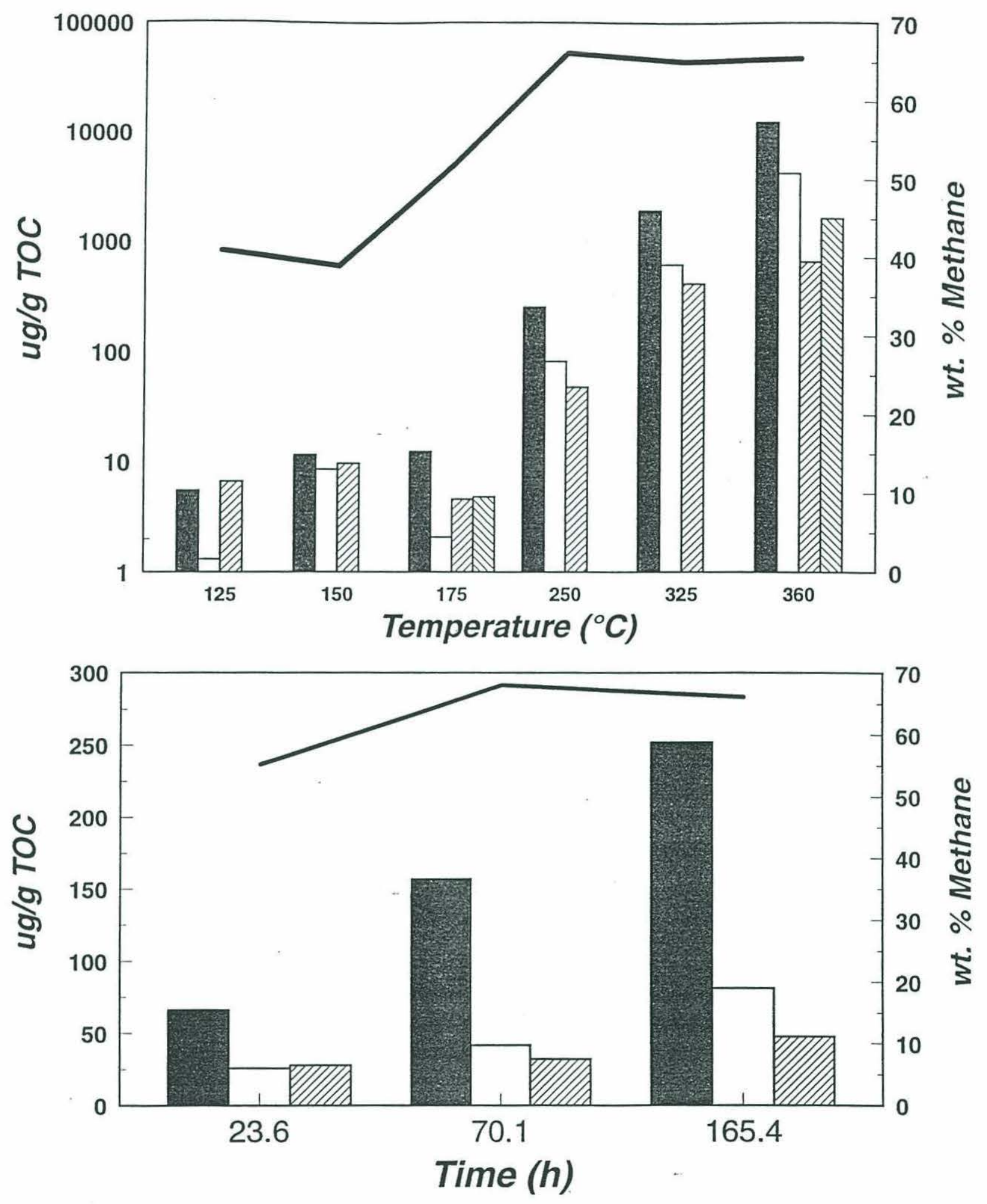

Methane Ethane Propane

एव एवत्र

Figure 7. (a) Log amounts of $\mathrm{CH}_{4}, \mathrm{C}_{2} \mathrm{H}_{6}, \mathrm{C}_{3} \mathrm{H}_{8}$, and iso- $+n-\mathrm{C}_{4} \mathrm{H}_{10}$ hydrocarbons generated from hydrous-pyrolysis of Smackover shale at all experimental temperatures versus wt. $\% \mathrm{CH}_{4}$. (b) Amounts of $\mathrm{CH}_{4}, \mathrm{C}_{2} \mathrm{H}_{6}, \mathrm{C}_{3} \mathrm{H}_{8}$, and iso- $+n$ $\mathrm{C}_{4} \mathrm{H}_{10}$ hydrocarbons generated during the $250^{\circ} \mathrm{C}$ Smackover shale hydrouspyrolysis experiment versus wt.\% $\mathrm{CH}_{4}$. 


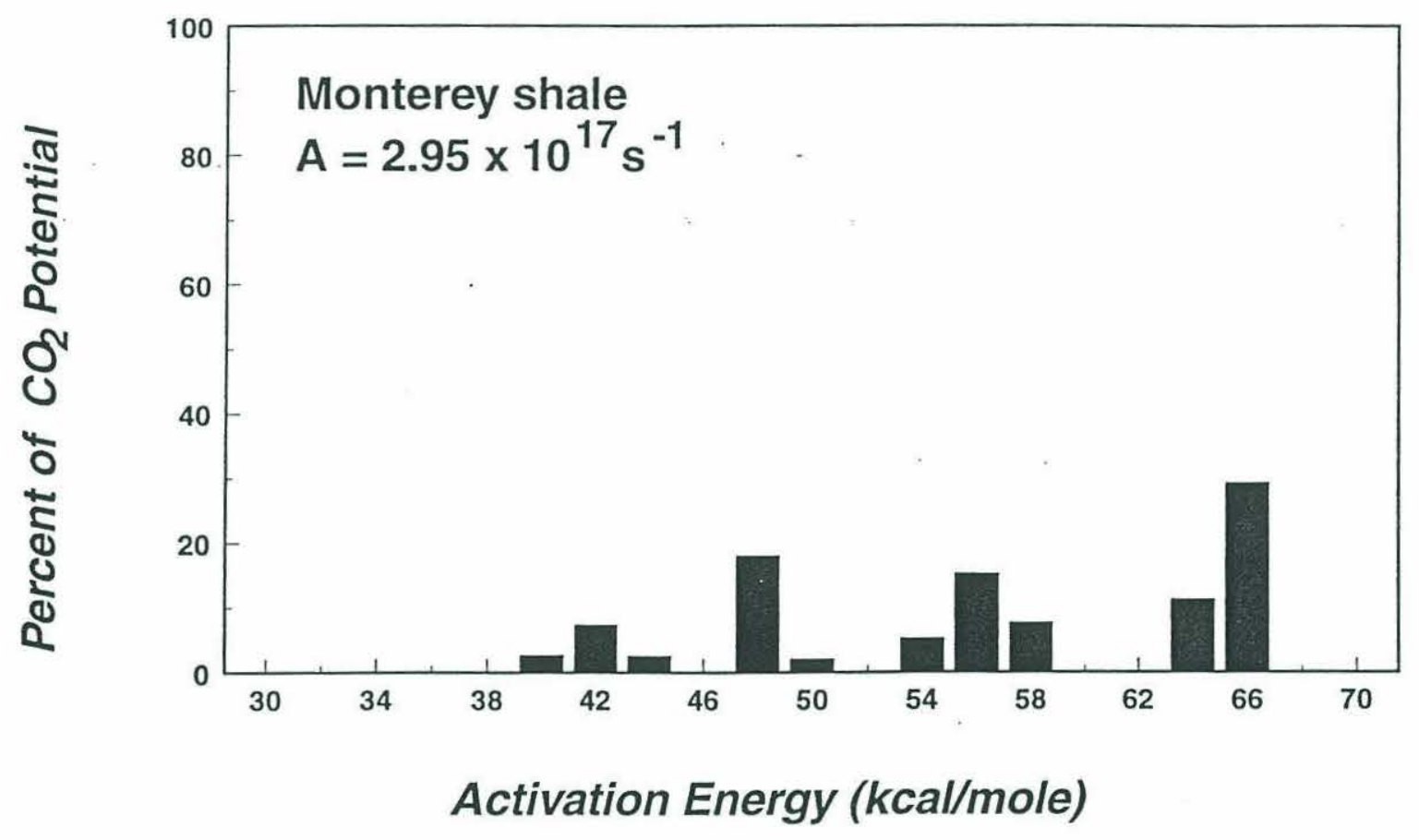

Figure 8. Distribution of activation energies and the pre-exponential factor for $\mathrm{CO}_{2}$ generated during hydrous-pyrolysis of Monterey shale. The computer code KINETICS (Braun and Burnham, 1990) was used to calculate these values. 


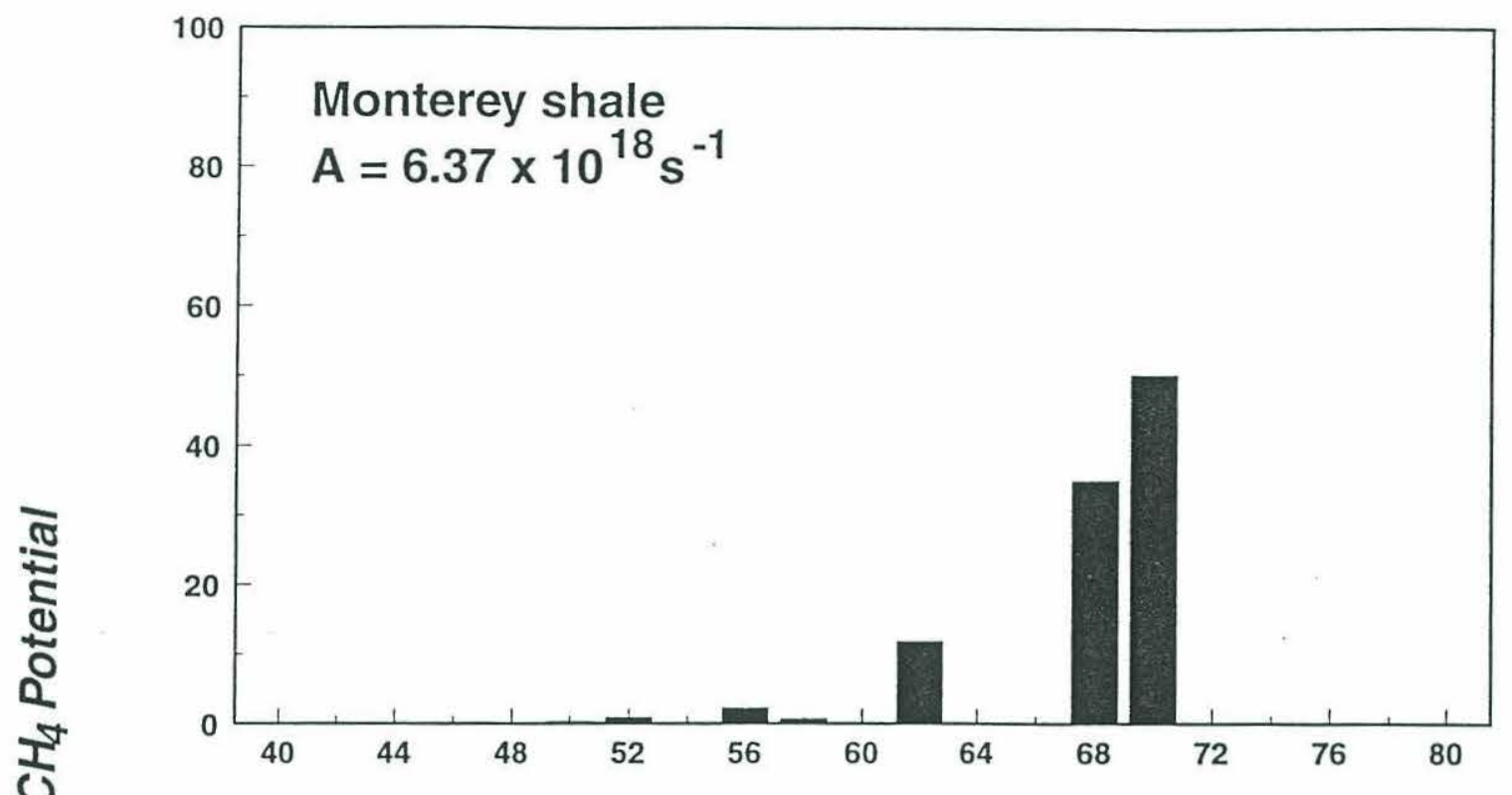

ปั

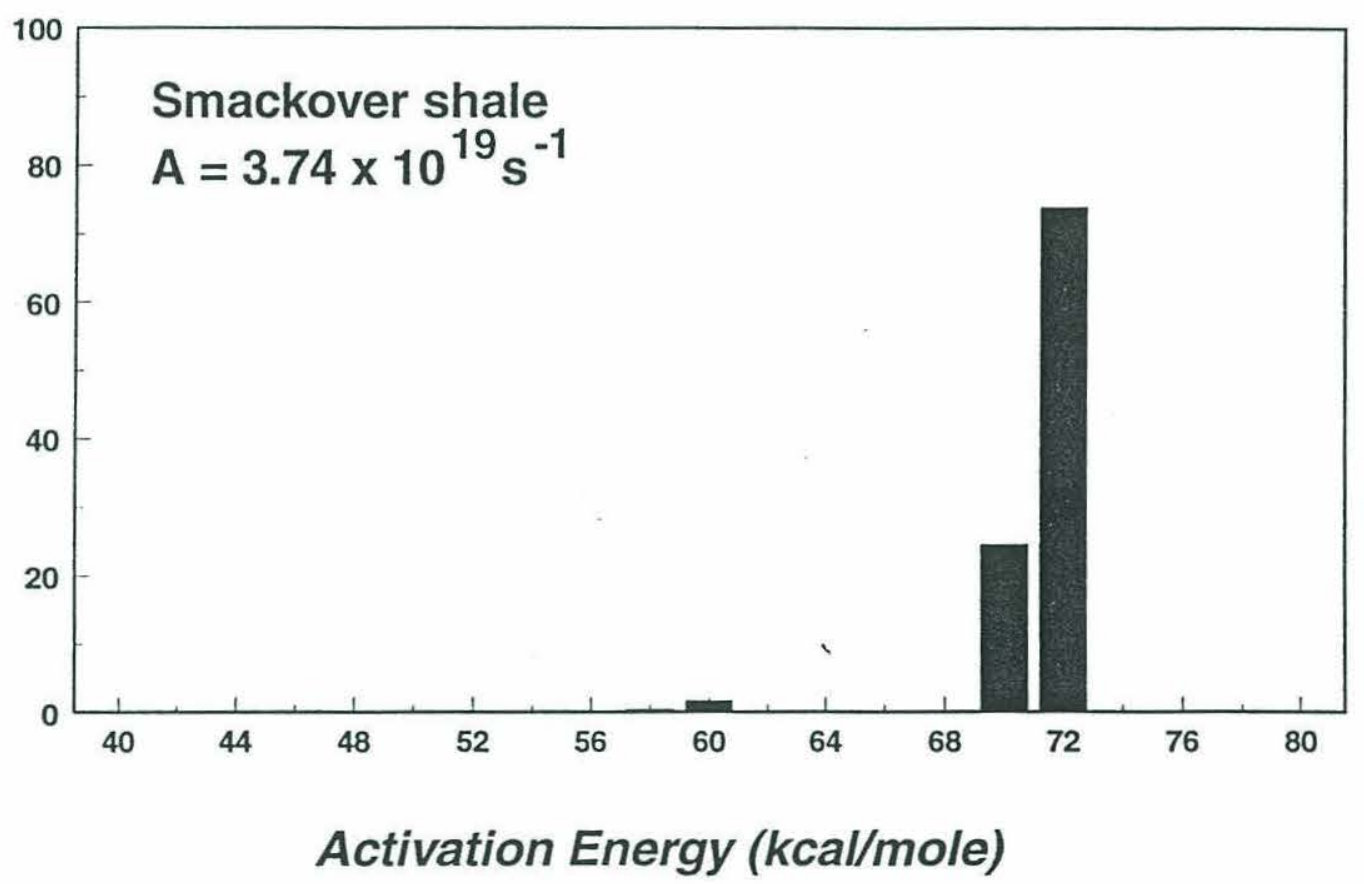

Figure 9. Distribution of activation energies and the pre-exponential factors for $\mathrm{CH}_{4}$ generated during hydrous-pyrolysis of Monterey and Smackover shales. The computer code KINETICS (Braun and Burnham, 1990) was used to calculate these values. 


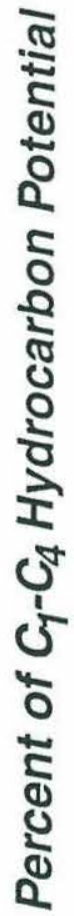

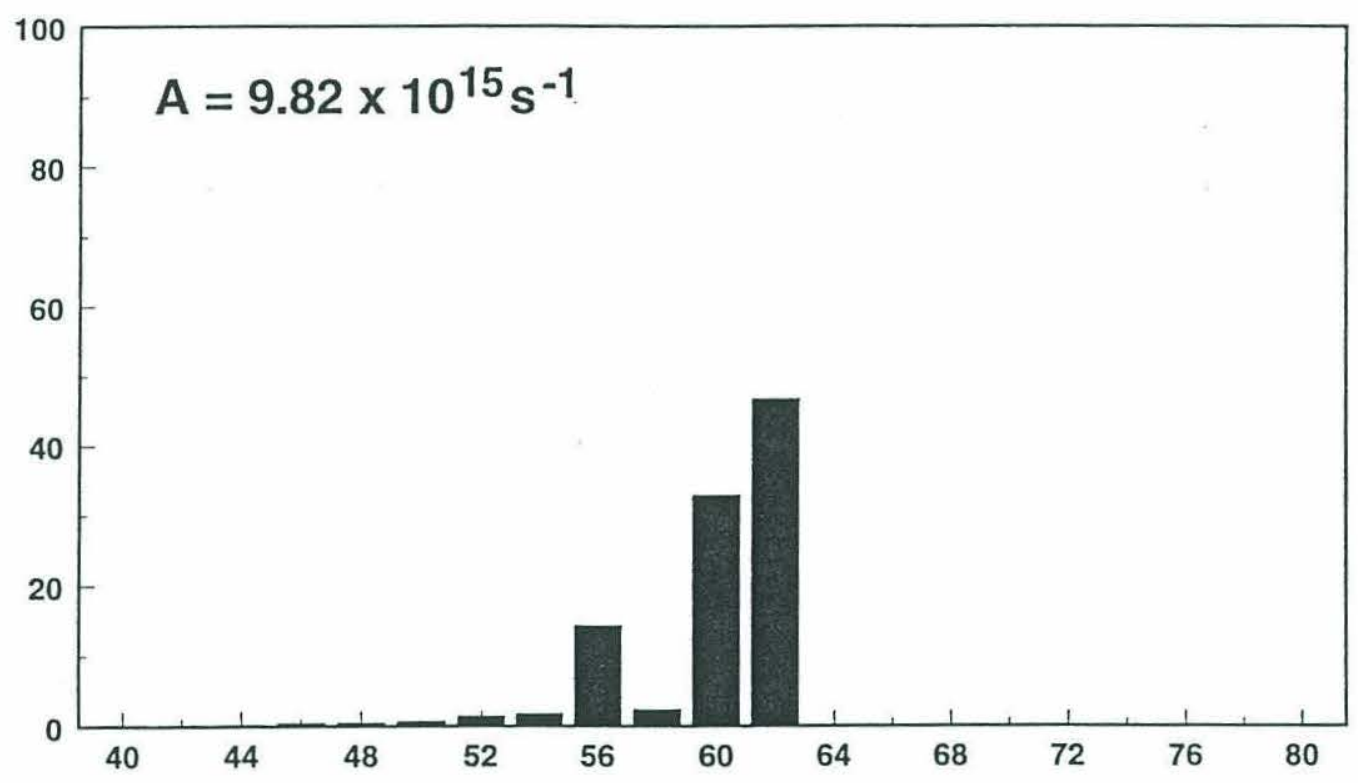

Activation Energy ( $\mathrm{kcal} / \mathrm{mole})$

Figure 10. Distribution of activation energies and the pre-exponential factor for total $\mathrm{C}_{1}$ $\mathrm{C}_{4}$ hydrocarbons generated during hydrous-pyrolysis of Monterey shale. The computer code KINETICS (Braun and Burnham, 1990) was used to calculate these values. 


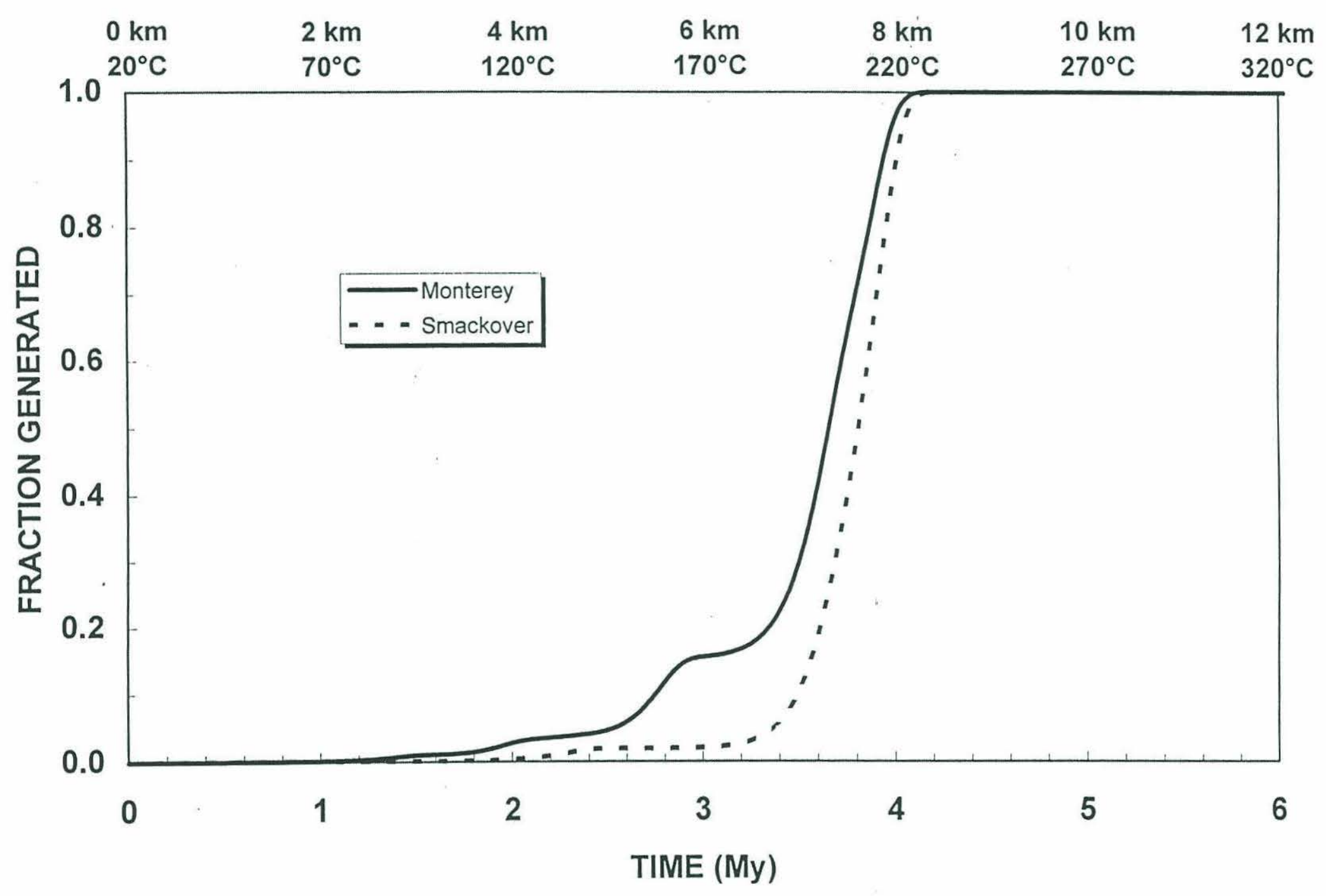

Figure 11. $\mathrm{CH}_{4}$ generation curves for Monterey and Smackover shales in a hypothetical sedimentary basin. The basin was generated using the computer code KINETICS (Braun and Burnham, 1990). 


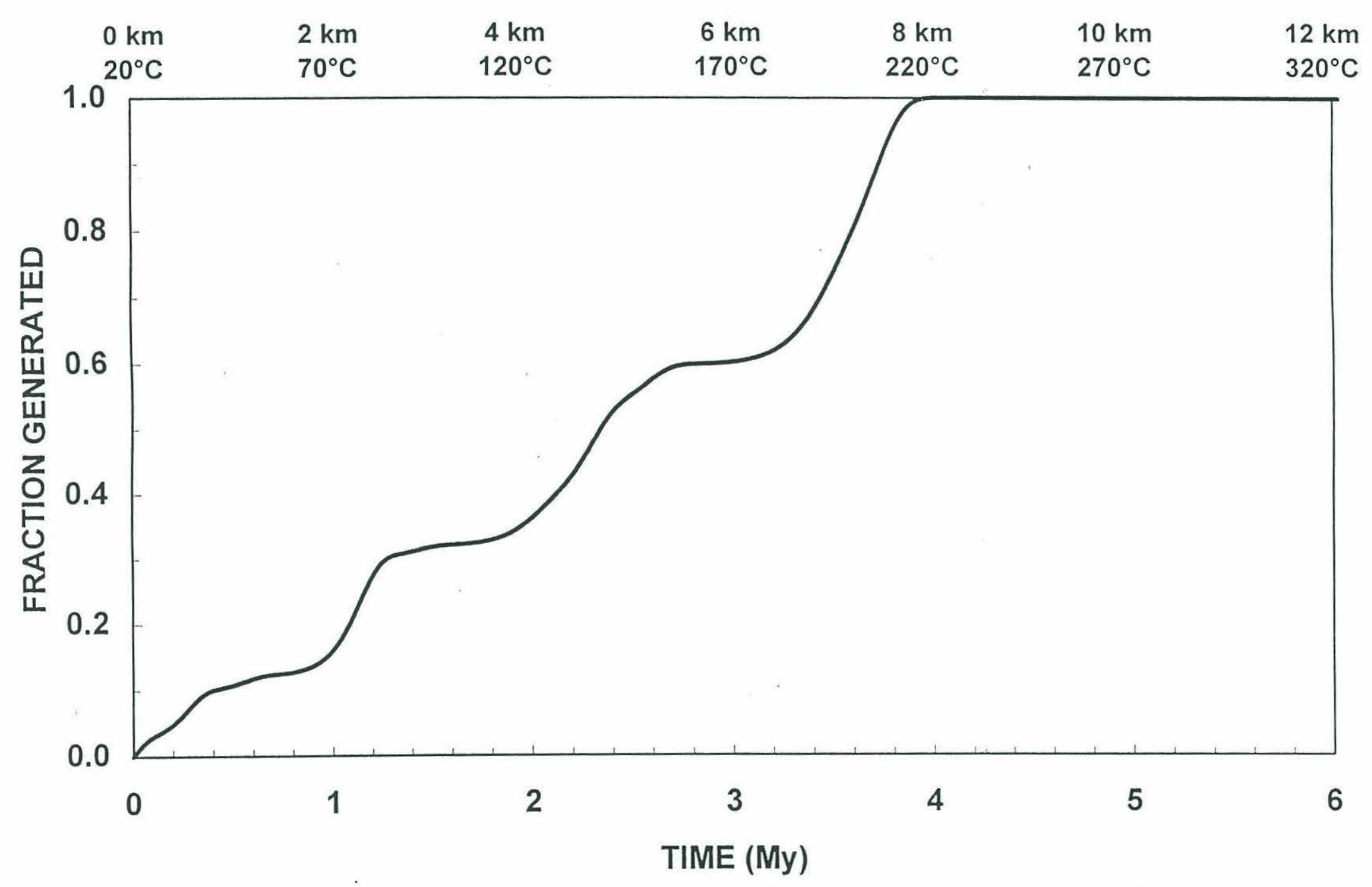

Figure 12. $\mathrm{CO}_{2}$ generation curve for Monterey shale in a hypothetical sedimentary basin. The basin was generated using the computer code KINETICS (Braun and Burnham, 1990). 


\section{CHAPTER 3}

\section{AMS- ${ }^{14} \mathrm{C}$ Dating of Individual Compounds Isolated from Recent Marine Sediments}

\section{Introduction}

The burial of organic carbon in marine sediments and subsequent formation of kerogen are important pathways in the global carbon cycle and are critical in maintaining present-day atmospheric oxygen concentrations (Berner, 1989; Hedges, 1992). The burial of newly formed organic carbon acts as a source of molecular oxygen which must have a compensatory sink, otherwise atmospheric oxygen concentrations would increase over time to levels $150 \%$ greater than at present (Berner 1989, Hedges, 1992). Fortunately, oxygen is consumed by the weathering of kerogen exposed in uplifted continental sedimentary rocks (Berner, 1989). This source and sink of oxygen are believed to be in balance and may act as a negative feedback control for oxygen production (Berner, 1989).

Marine sediments are the primary repository for organic carbon through the formation of sedimentary rocks over geologic time. Sedimentary rocks contain over $99 \%$ of the total organic carbon on Earth (Hedges, 1992). Greater than $90 \%$ of the organic carbon contained in this reservoir is in the form of kerogen (Hedges, 1992). Kerogens are highly cross-linked, oxygen-poor, organic polymers insoluble in common organic solvents and non-oxidizing acids such as $\mathrm{HCl}$ and $\mathrm{HF}$ (Durand, 1980). The mechanisms leading to the formation of kerogen are poorly understood, however, two general processes are typically cited. In the first, kerogen is formed through the enzymatic depolymerization of sedimentary macromolecules, such as polysaccharides and proteins, followed by condensation of the resulting oligomers and monomers with other organic compounds, such as low molecular-weight lipids (Durand, 1980; Tissot and Welte, 1984; de Leeuw and Largeau, 1993). Conversely, Tegelaar et al. (1989) proposed that kerogens are actually physical mixtures of selectively preserved refractory biomolecules which have undergone little or no alteration by biodegradation. Thus, the formation of kerogen is highly dependent on the type of organic matter which is deposited at the sedimentwater interface and the extent to which it is preserved during burial. 
The remineralization of kerogen through continental weathering has long been believed to be essentially complete--a critical assumption made in models of the biogeochemical carbon cycle (Berner, 1989). Several researchers, however, have discovered ${ }^{14} \mathrm{C}$-poor organic matter in modern marine sediments (Sackett et al., 1974; Benoit et al., 1979; Barrick and Hedges, 1981; Rowland and Maxwell, 1984). This would indicate that some portion of organic matter which is buried, uplifted and weathered is not completely remineralized and may even have been recycled more than once, if not several times. The result of incomplete remineralization would be the deposition of partially degraded kerogen in all carbon reservoirs (Hedges, 1992). Thus, a significant portion of organic matter in sediments which is difficult to identify may be humic substances and reactive molecules formed from the oxidative degradation of kerogen (Hatcher and Spiker, 1988; Hedges, 1992). It is therefore possible that sedimentation rates based on ${ }^{14} \mathrm{C}$ dating of bulk sediment total organic carbon (TOC) may be skewed by the presence of recycled kerogen.

The presence of recycled kerogen and its degradative products in modern marine sediments would greatly alter present views of the global carbon cycle. Knowledge of organic carbon preservation in marine sediments is crucial to understanding the global carbon cycle as it stands today and how it will change with continued anthropogenic perturbations. In addition, controls on organic carbon burial and preservation must be understood in order to interpret the sedimentary record in terms of paleoproductivity and paleocirculation. Numerous studies have been conducted with this in mind (Calvert et al., 1987; Calvert et al., 1991; Cowie and Hedges, 1992; Lee, 1992; Sun et al., 1993). Due to the recalcitrant nature of kerogen, however, these studies were unable to directly access the relative importance of these refractory compounds. Nevertheless, several researchers eluded to the potential significance of kerogen as a control of carbon preservation in oxic/anoxic marine sediments (Cowie and Hedges, 1992a; Lee, 1992).

This study employed Preparative Capillary Gas Chromatography (PCGC) to determine the relative contributions of marine biomass (primary production), modern terrestrial and recycled sedimentary organic matter co-deposited in marine sediments. Recently developed by Eglinton et al. (1996), PCGC has enabled us to isolate pure, 
individual biomarkers from complex mixtures of sedimentary organic matter.

Compounds were isolated in sufficient quantity to obtain ${ }^{14} \mathrm{C}$ ages through accelerator mass spectrometry (AMS). For this study, recent marine sediments were obtained from the Black Sea and Arabian Sea. Biomarkers obtained from these sediments prove conclusively that organic matter co-deposited in marine settings represent a vast range in radiocarbon ages. Thus, attributing a single ${ }^{14} \mathrm{C}$ age to the bulk sediment masks the internal isotopic heterogeneity which is crucial to fully understanding the global biogeochemical carbon cycle.

\section{Methods}

\section{Sample Description and Preparation}

Sediment samples were obtained from the Arabian Sea and the Black Sea (Figs. 1a and $1 \mathrm{~b})$. The Arabian Sea sediment core $6 \mathrm{BC}$ was collected 10/1/94 from $17^{\circ} 48.721^{\text {' }}$ N, 57³0.293' E using a box core during leg TN041 of the R.V. Thomas G. Thompson. The core was collected from $747 \mathrm{~m}$ water depth within the oxygen minimum zone. Once aboard, the core was sectioned at $2 \mathrm{~cm}$ intervals, placed in Scotchpak-brand ${ }^{\circ}$ bags, heatsealed and frozen within 6 hrs of collection. The core appeared homogenous and consisted of a soft, wet foraminiferal sand. Tube worm burrows were located throughout the core and several mollusks were alive on the surface of the core. $\mathrm{H}_{2} \mathrm{~S}$ was detected by odor at $20 \mathrm{~cm}$ and below. The Black Sea sediment core BC4 was obtained 5/14-28/1988

from station 2 located in the West-Central basin ( $\left.42^{\circ} 51^{\prime} \mathrm{N}, 31^{\circ} 57^{\prime} \mathrm{E}\right)$ during leg 134-9 of the R.V. Knorr Black Sea Expedition. The core was obtained from 2129 m water depth and sampled at $0.5 \mathrm{~cm}$ horizons.

\section{Solvent Extraction}

After thawing the cores, approximately $5 \mathrm{~g}$ of sediment from each interval was removed, dried at $<40^{\circ} \mathrm{C}$ and reweighed to determine the dry weight/wet weight ratio. A fraction of the dried sediment was removed for elemental analysis while approximately $100 \mathrm{mg}$ was repeatedly treated with $2 \mathrm{~N} \mathrm{HCl}$, sonicated and oven dried $\left(50^{\circ} \mathrm{C}\right)$ until no carbonate remained. The acid-hydrolyzed sediments were used for coulometric analysis, 
elemental analysis and $\delta^{13} \mathrm{C}$ and $\Delta^{14} \mathrm{C}$ determinations. The remaining wet sediment from the 2-4 cm interval of the Arabian Sea core $6 \mathrm{BC}$ was centrifuged to remove pore water. The moist sediment (approximately $1031 \mathrm{~g}$ dry) was transferred to pre-extracted cellulose thimbles and soxhlet-extracted with $100 \% \mathrm{CH}_{3} \mathrm{OH}$ for $48 \mathrm{hrs}$ then $100 \% \mathrm{CH}_{2} \mathrm{Cl}_{2}$ for 48 hrs. The $\mathrm{CH}_{3} \mathrm{OH}$ (dark gold/brown) and $\mathrm{CH}_{2} \mathrm{Cl}_{2}$ (dark green) extracts were rotoevaporated to approximately $300 \mathrm{~mL}$ and back-extracted with $125 \mathrm{~mL}$ of $\mathrm{KMnO}_{4}$-distilled $\mathrm{H}_{2} \mathrm{O}$ and $\mathrm{CH}_{2} \mathrm{Cl}_{2}$. The lower organic phases were combined, roto-evaporated to approximately $300 \mathrm{~mL}$ and allowed to sit for $24 \mathrm{hrs}$ with anhydrous $\mathrm{Na}_{2} \mathrm{SO}_{4}$. The extract was then filtered ( $0.45 \mu \mathrm{m}$ teflon filters) and transferred to $500 \mathrm{~mL}$ volumetric flask.

The wet sediment from each $0.5 \mathrm{~cm}$ interval from $4-7 \mathrm{~cm}$ of Black Sea core BC4 was sonic-extracted sequentially with $\mathrm{CH}_{3} \mathrm{OH}$ and increasing concentrations of $\mathrm{CH}_{2} \mathrm{Cl}_{2}$. The solvent extracts from each $0.5 \mathrm{~cm}$ interval were combined (to provide sufficient material for compound isolation and $\mathrm{AMS}-{ }^{14} \mathrm{C}$ analysis), back-extracted, treated with anhydrous $\mathrm{Na}_{2} \mathrm{SO}_{4}$ and filtered similar to above.

Aliquots ( $0.1 \%)$ of the total lipid extracts (TLE) from core $6 \mathrm{BC}(2-4 \mathrm{~cm})$ and core BC4 $(4-7 \mathrm{~cm})$ were dryed under $\mathrm{N}_{2}$ and transesterified. Transesterification was accomplished by heating the samples at $70^{\circ} \mathrm{C}$ for $10 \mathrm{hrs}$ in the presence of a $95: 5$ mixture of $\mathrm{CH}_{3} \mathrm{OH}$ and sub-boiled $\mathrm{HCl}$ under a $\mathrm{N}_{2}$ atmosphere. Once cooled the mixture was back-extracted with $\mathrm{KMnO}_{4}$-distilled $\mathrm{H}_{2} \mathrm{O}$ and $\mathrm{C}_{6} \mathrm{H}_{14}$. The upper phase was pipetted off and passed over $\mathrm{Na}_{2} \mathrm{SO}_{4}$ to remove water. Derivatization of alcohols was achieved by drying the transesterified fraction, adding equal amounts of pyridine and BSTFA $\left(\right.$ Regisil ${ }^{\circ}$ ) and heating at $60^{\circ} \mathrm{C}$ for $15 \mathrm{~min}$. Fractions of both crude TLE removed prior to transesterification and derivitization for $\Delta^{14} \mathrm{C}$ determinations.

\section{Column Chromatography}

The majority of the total lipid extracts were roto-evaporated until they were viscous then dried onto several grams of 70 mesh quartz sand under a $\mathrm{N}_{2}$ stream. Flash chromatography was carried out using a $45.7 \times 5.0 \mathrm{~cm}$ i.d. column packed with $250 \mathrm{~mL}$ of a flash-chromatography $\mathrm{SiO}_{2}$ gel slurry in $\mathrm{C}_{6} \mathrm{H}_{14}$. Once the dried extract / sand mixture was transferred to the top of the column, separation was accomplished according to the following elution scheme for the Black Sea TLE: 


\begin{tabular}{c} 
Fraction \# \\
\hline 1 \\
2 \\
3 \\
4 \\
5 \\
6
\end{tabular}

$\frac{\text { Solvent(s) }}{100 \% \mathrm{C}_{6} \mathrm{H}_{14}}$
$50 \% \mathrm{C}_{6} \mathrm{H}_{5} \mathrm{CH}_{3} / \mathrm{C}_{6} \mathrm{H}_{14}$
$10 \% \mathrm{C}_{2} \mathrm{H}_{5} \mathrm{CO}_{2} \mathrm{CH}_{3} / \mathrm{C}_{6} \mathrm{H}_{14}$
$20 \% \mathrm{C}_{2} \mathrm{H}_{5} \mathrm{CO}_{2} \mathrm{CH}_{3} / \mathrm{C}_{6} \mathrm{H}_{14}$
$100 \% \mathrm{C}_{2} \mathrm{H}_{5} \mathrm{CO}_{2} \mathrm{CH}_{3}$
$100 \% \mathrm{CH}_{3} \mathrm{OH}$

Compounds
Aliphatic hydrocarbons
Aromatic hydrocarbons
Ketones
Alcohols
Polars
Polars

For the Arabian Sea TLE, fractions 2, 3 and 4 were eluted concurrently using 100\% $\mathrm{CH}_{2} \mathrm{Cl}_{2}$ while fractions 5 and 6 were eluted with $100 \% \mathrm{CH}_{3} \mathrm{OH}$.

Elemental sulfur was removed from the Arabian Sea fraction \#1 by passing the sample through a column packed with activated $\mathrm{Cu}$ granules. As the sample was passed through the column the $\mathrm{Cu}$ turned from shiny to black indicating the presence of $\mathrm{S}$. Elemental sulfur was not present in the Black Sea fraction \#1. Saturated hydrocarbons in fraction \#1 from both samples were separated from unsaturated compounds using a $\mathrm{AgNO}_{3}-\mathrm{SiO}_{2}$ column. The column $(45.7 \times 1.9 \mathrm{~cm})$ was packed dry with $50 \mathrm{~mL}$ flashchromatography $\mathrm{SiO}_{2}$ gel after which $100 \mathrm{~mL}$ of a saturated $\mathrm{AgNO}_{3}$ solution $\left(3: 1 \mathrm{C}_{2} \mathrm{H}_{3} \mathrm{OH}\right.$ / $\mathrm{KMnO}_{4}$-distilled $\mathrm{H}_{2} \mathrm{O}$ ) was slowly ( $1 \mathrm{~mL} / \mathrm{min}$ ) passed over the $\mathrm{SiO}_{2}$ gel. The column was rinsed with $\mathrm{CH}_{3} \mathrm{COCH}_{3}$ and dryed with $\mathrm{N}_{2}$. After adding $\mathrm{C}_{6} \mathrm{H}_{14}$ the aliphatic hydrocarbon fractions were added. The saturated hydrocarbons were eluted with $350 \mathrm{~mL}$ of $\mathrm{C}_{6} \mathrm{H}_{14}$ followed by elution of the unsaturated fraction with $350 \mathrm{~mL}$ of $\mathrm{C}_{2} \mathrm{H}_{5} \mathrm{OC}_{2} \mathrm{H}_{5}$. The column was wrapped in Al-foil during the entire process to prevent photo-oxidation of the $\mathrm{AgNO}_{3}$. The saturated hydrocarbons were roto-evaporated to less than $10 \mathrm{~mL}$ while the unsaturated compounds were taken to dryness. Both were then dissolved in $\mathrm{C}_{6} \mathrm{H}_{14}$.

For this study, compounds were isolated from the saturated and unsaturated hydrocarbon fractions from both the Arabian Sea and Black Sea. Individual compounds were also isolated from the Black Sea fraction \#4 (alcohols), however, $\Delta^{14} \mathrm{C}$ determinations have not been made yet. All hydrocarbon fractions were dissolved in $\mathrm{C}_{6} \mathrm{H}_{14}$ while the alcohol fraction was dissolved in $\mathrm{CH}_{2} \mathrm{Cl}_{2}$ during preparative capillary gas chromatography. 


\section{Preparative Capillary Gas Chromatography (PCGC)}

The following is a brief description of the preparative capillary gas chromatograph (PCGC). For a more thorough overview of the PCGC system see Eglinton et al. (1996). The PCGC device (Fig. 2) consists of a Hewlett Packard 5890 Series II gas chromatograph equipped with a flame ionization detector (FID), an HP 7673 autoinjector, electronic pressure control and a Gerstel ${ }^{\circ}$ Cooled Injection System (CIS). The GC is fitted with a $60 \mathrm{~m}$ megabore $(0.53 \mathrm{~mm}$ i.d.) fused silica capillary column coated with a cross-bonded methylsilicone phase $\left(\mathrm{R}_{\mathrm{TX}-1}, \operatorname{Restec}^{\circ}\right.$; film thickness $\left.0.5 \mu \mathrm{m}\right)$. The GC column leads through a heated $\left(\sim 315^{\circ} \mathrm{C}\right)$ transfer line to a Gerstel Preparative Switching Device (PSD). The PSD consists of an 8-port zero-dead-volume valve, in a heated oven $\left(\sim 310^{\circ} \mathrm{C}\right)$, which connects to seven $\mathrm{J} \& \mathrm{~W}^{\circ}$ deactivated fused silica capillary columns (18 $\mathrm{cm} \times 0.32 \mathrm{~mm}$ i.d.) which are, in turn, connected to $200 \mu \mathrm{L}$ glass U-tube traps (6 sample traps and one waste trap). The traps are cooled $\left(-10^{\circ} \mathrm{C}\right)$ by a Neslab ${ }^{\circ} \mathrm{RTE}-140$ circulating cooler.

For this study it is necessary to isolate individual compounds of sufficient purity and quantity for AMS $-{ }^{14} \mathrm{C}$ measurements. In order to accomplish this in a reasonable time span (1 trapping sequence takes $\sim 7$ days) relatively large (10 $\mu \mathrm{L})$ injections are made using the HP 7673 autoinjector. In order to eliminate as much solvent prior to transferring the sample to the chromatographic column, the CIS utilizes a temperature program independent from that of the GC. The CIS temperature program used for the present study was from $40^{\circ} \mathrm{C}$ (initial hold time, $0.15 \mathrm{~min}$ ) to $330^{\circ} \mathrm{C}$ (final hold time, 8 $\min$ ) at a rate of $12^{\circ} \mathrm{C} \mathrm{s}^{-1}$. Once the sample is separated chromatographically, the eluting compounds pass through a zero-dead-volume splitter arranged to send $<1 \%$ of the flow to the FID and $>99 \%$ to the preparative switching device (PSD).

The chromatographic traces generated from the FID are used to determine retention times for the individual compounds of interest. These retention times are then used to program the PSD. The 8-port zero-dead-volume valve of the PSD is back-

pressure controlled by solenoid valves located after the traps which minimizes the potential for contamination. Up to 50 time windows can be entered for each trap and opening/closing times are precise to within $0.6 \mathrm{sec}$. Due to the reproducibility of retention 
times afforded by microprocessor control of the autoinjector, CIS and GC, trapping windows can be defined within narrow tolerances. During this study the opening and closing times programmed for an individual trap were typically 0.4-0.6 min apart.

\section{Graphite Target Preparation and AMS $-{ }^{14} \mathrm{C}$ Analysis}

Once the compounds had been isolated each U-tube was detached and rinsed with $1 \mathrm{~mL}$ of $\mathrm{CH}_{2} \mathrm{Cl}_{2}$ to transfer the samples to quartz combustion tubes ( $20 \mathrm{~cm} \mathrm{x} 9 \mathrm{~mm}$ o.d.). Once transferred, an aliquot $(50 \mu \mathrm{L})$ was removed for HRGC and GC-MS and spiked with $50 \mu \mathrm{L}$ of a $n-\mathrm{C}_{32}$ internal standard for quantification. The solvent present in the combustion tube was then removed under a stream of high purity $\mathrm{N}_{2}$. $\mathrm{CuO}(\sim 2 \mathrm{mg} / \mu \mathrm{g}$

C) was added to the combustion tube and any residual solvent was removed by evacuating the tube to $10^{-6}$ Torr in a dry-ice/isopropanol bath. The bath was replaced by liquid $\mathrm{N}_{2}$ and the tube was flamed sealed while under vacuum. The isolated compounds were converted to $\mathrm{CO}_{2}$ by heating at $850^{\circ} \mathrm{C}$ for $5 \mathrm{hrs}$. Once cool, the $\mathrm{CO}_{2}$ sample was introduced to a vacuum line, purified and quantified. The $\mathrm{CO}_{2}$ sample was converted to graphite according to the procedures outlined by McNichol et al. (1992). Briefly, the $\mathrm{CO}_{2}$ sample was heated at $600^{\circ} \mathrm{C}$ for $5 \mathrm{hrs}$ in the presence of a Co catalyst (1.0-1.5 mg) and $\mathrm{H}_{2}$ (2.5 x sample pressure). $\mathrm{H}_{2} \mathrm{O}$ produced during the reaction was trapped in a liquid $\mathrm{N}_{2}$ bath. Once cool the graphite samples were stored in a desiccator until they were pressed into $\mathrm{Al}$ cartridges to form targets for AMS.

AMS- ${ }^{14} \mathrm{C}$ analyses of the isolated compounds were conducted at the National Ocean Sciences AMS (NOSAMS) facility here at WHOI and at the Lawrence Livermore National Laboratory's (LLNL) Center for AMS in Livermore, CA. $\mathrm{CO}_{2}$ samples

generated at NOSAMS were also analyzed for stable $\mathrm{C}$ isotopic compositions $\left(\delta^{13} \mathrm{C}\right)$ on a $\mathrm{VG}^{\circ}$ Prism mass spectrometer.

\section{High Resolution Capillary GC (HRGC) and GC-MS}

High resolution capillary GC was used after PCGC to determine the purity and yields of isolated compounds. The HRGC consists of a Hewlett Packard ${ }^{\circledR} 5890$ Series II $^{\circ}$ GC fitted with an HP 7673 autoinjector, electronic pressure control and a FID. 
Separation was achieved on a $\mathrm{J} \& \mathrm{~W}^{\star} \mathrm{DB}-1$ column $(60 \mathrm{~m} \times 0.32 \mathrm{~mm}$, film thickness 0.25

$\mu \mathrm{m})$. Data were acquired and integrated using Chromperfect ${ }^{\circ}$ software. GC-MS analysis were performed using a similarly equipped HP 5890, interfaced to a VG $\mathrm{VG}^{\odot}$ Autospec-Q mass spectrometer. Spectra were scanned over the range 50-600 amu with a cycle time of $1 \mathrm{sec}$. Electron impact ionization (EI) at $50 \mathrm{eV}$ was used for all analyses.

\section{Bulk Sediment Isotopic and Elemental Analyses}

Stable carbon isotopic measurements $\left(\delta^{13} \mathrm{C}\right)$ of the acid-hydrolyzed bulk sediment samples were made at the Marine Biological Laboratory (MBL) using a Finnigan ${ }^{\star}$ Delta-S mass spectrometer and at the NOSAMS facility using a VG Prism mass spectrometer. Solid samples were combusted on-line followed by conventional isotope ratio-mass spectrometry (Fry et al., 1992a). The sediment samples were rinsed with distilled $\mathrm{H}_{2} \mathrm{O}$ and centrifuged prior to being analyzed at the NOSAMS facility. As shown in Table 1, the $\delta^{13} \mathrm{C}$ results of the water-rinsed samples were on average $1.2 \%$ lighter than those that were not rinsed prior to analysis. It is possible that this discrepancy is due to the removal of the most labile organic fractions, such as acid-hydrolyzable proteins, during waterrinsing and centrifugation. The $\delta^{13} \mathrm{C}$ values measured at the NOSAMS facility were used to calculate the $\Delta^{14} \mathrm{C}$ values of the bulk sediment samples. However, the discrepancy between $\delta^{13} \mathrm{C}$ values could alter the $\Delta^{14} \mathrm{C}$ determinations by no more than $0.5 \%$, which is well within the $\Delta^{14} \mathrm{C}_{\mathrm{TOC}}$ error given in Table 1 . For clarity, only the $\delta^{13} \mathrm{C}$ values measured at the NOSAMS facility will be discussed further. ${ }^{14} \mathrm{C}$ determinations of the bulk sediment samples were made at WHOI NOSAMS facility in the same manner as described above for isolated compounds. Elemental analyses (TC, H, N) of the bulk sediments were conducted on a Perkin Elmer ${ }^{\oplus} 2400$ CHN Elemental Analyzer. Measurements of total inorganic carbonate (TIC) were made using a UIC ${ }^{\circledast}$ Inc. Coulometrics $\mathrm{CO}_{2}$ Coulometer and total organic carbon (TOC) was determined by difference. 


\section{Results and Discussion}

\section{Bulk Sediment Composition}

The elemental and isotopic composition of the bulk sediment samples are listed in Table 1. The organic carbon content of the Arabian Sea core $6 \mathrm{BC}$ ranged from 4.20 to $6.66 \mathrm{wt} . \%$ in the $8-10$ and $2-4 \mathrm{~cm}$ intervals, respectively. The $4-7 \mathrm{~cm}$ section from the Black Sea core BC4 exhibited a slightly wider variance in organic carbon content, ranging from 3.94 to $7.66 \mathrm{wt} . \%$. The organic rich nature of both cores is representative of the depositional environments present at both locations. In the Arabian Sea, primary production increases dramatically during the summer months due to the monsoon-driven upwelling of nutrients (Paropkari et al., 1992). The Black Sea also experiences seasonal blooms in marine primary productivity (Karl and Knauer, 1991) in addition to high concentrations of terrigenous material from the Danube and Dnepr rivers (Simoneit, 1977). Several studies have shown that the amount of organic carbon delivered to the sediments is the principal control on the accumulation of organic matter in sediments (Calvert , 1987; Pedersen and Calvert, 1990; Calvert and Pedersen 1992). As a result, recent sediments from both the Oman margin and the Black Sea exhibit relatively high organic carbon contents (Calvert et al., 1991; Paropkari et al., 1992; Pedersen et al., 1992).

The stable carbon isotopic compositions of the Arabian and Black Sea cores illustrate differences in both the sources of sedimentary organic matter and the carbonate systems at each site (Table 1). $\delta^{13} \mathrm{C}$ measurements of core $6 \mathrm{BC}$ vary from -21.4 to -21.7 $\%$, which are within the range cited for marine organic matter (-19 to $-23 \%$, Deines, 1980). In contrast, the $\delta^{13} \mathrm{C}$ values of the Black Sea sediment samples range from -25.0 to $-25.2 \%$. These lighter $\delta^{13} \mathrm{C}$ values are attributable to both a greater contribution of terrestrial organic matter (-24 to $-32 \%$, Sackett and Thompson,1963) and to an isotopically lighter DIC pool in the Black Sea compared to the Arabian Sea. The anoxic conditions present in the Black Sea lead to elevated total $\mathrm{CO}_{2}$ values due to organic matter degradation through sulfate reduction (Goyet et al., 1991). As $\mathrm{CO}_{2}$ concentrations increase with depth (Goyet et al., 1991) the ${ }^{13} \mathrm{C}$ content declines (Kroopnick, 1985; Fry et al., 1992b; Freeman and Wakeham, 1992). Thus, the $\delta^{13} \mathrm{C}$ values of photoautotrophic 
organisms become isotopically lighter as do the heterotrophic organisms feeding on the phytoplankton. As a result, marine organic matter delivered to the sediments in the Black Sea is isotopically lighter than in the Arabian Sea.

The atomic ratio of carbon to nitrogen $(\mathrm{C} / \mathrm{N})_{\mathrm{a}}$ provides further evidence of differing organic matter sources in the Arabian and Black Sea (Table 1). Terrestrial organic matter is depleted in nitrogen relative to marine organic matter (Emerson and Hedges, 1988). Thus, inputs of terrigenous material to the sediments will result in elevated $(\mathrm{C} / \mathrm{N})_{\mathrm{a}}$ ratios. Higher $(\mathrm{C} / \mathrm{N})_{\mathrm{a}}$ ratios were observed in the Black Sea samples $\left((\mathrm{C} / \mathrm{N})_{\mathrm{a}}=13.2\right.$ and 14.8) as compared to those from the Arabian Sea $\left((\mathrm{C} / \mathrm{N})_{\mathrm{a}}=8.6\right.$ to 11.7), indicating a relatively stronger terrestrial signal in the Black Sea core.

The $\Delta{ }^{14} \mathrm{C}_{\text {Tос }}$ values of Arabian Sea core $6 \mathrm{BC}$ increase with depth from $-84.0 \pm 3.1$ $\% o(0-2 \mathrm{~cm})$ to $-136 \pm 2.5 \%$ o $(8-10 \mathrm{~cm})$ correspond to ages of 665 and $1130 \pm 25 \mathrm{yrs}$, respectively (Table 1). Similarly, the $\Delta^{14} \mathrm{C}_{\text {Toc }}$ values of Black Sea core BC4 ranged from $91.9 \pm 2.6$ to $-115 \pm 2.9 \%$ o, which equate to ages of 735 to $940 \pm 25$ yrs. However, the short depth intervals analyzed $(0.5 \mathrm{~cm})$ in core $\mathrm{BC} 4$ resulted in more variability with increasing depth (Table 1). Total lipid extracts were obtained from the 2-4 cm interval of Arabian Sea core $6 \mathrm{BC}$ and the entire 4-7 $\mathrm{cm}$ section of Black Sea core BC4 (Figs. 3a and 4). The average ${ }^{14} \mathrm{C}$ ages of these two intervals were 890 and $871 \mathrm{yrs}$, respectively. In contrast, the ${ }^{14} \mathrm{C}$ age of the total saturated hydrocarbon fraction from the Black Sea was $1310 \pm 150$ yrs (Table 2).

\section{Isolated Compounds}

\section{Trapping efficiency}

In total, twenty-four hydrocarbons were isolated from the Arabian and Black Sea cores utilizing the PCGC device (Table 2). The yields of isolated compounds, as determined by HRGC, ranged from approximately 6 to $176 \mu \mathrm{g} \mathrm{C}$ (Table 2). PCGC has been shown to be capable of isolating pure, individual compounds from complex mixtures in quantities sufficient for AMS ${ }^{14} \mathrm{C}$ dating (Eglinton et al., 1996). During this study all hydrocarbons were trapped cleanly and in sufficient amounts for radiocarbon analysis, with the exception of compounds P4-P6 which were combined to provide 
enough material for ${ }^{14} \mathrm{C}$ determinations (Table 2). An example of trapping efficiency is illustrated in Figure 5 which shows the HRGC traces of a series of $n$-alkanes isolated from the Black Sea $(4-7 \mathrm{~cm})$ saturated hydrocarbon fraction. Five, odd-numbered alkanes ( $n-\mathrm{C}_{23}$ to $n-\mathrm{C}_{31}$ ) were isolated from the total mixture (top trace). The absence of peaks other than those of the isolated compound and recovery standard shows just how cleanly the compounds were trapped (Fig. 5). By removing the desired compounds cleanly and completely from the total mixture, isotopic fractionation effects are minimized, allowing for the most accurate age determination for each compound.

There are three potential sources of error when preparing isolated compounds for AMS $-{ }^{14} \mathrm{C}$ analysis. The first is the presence of residual solvent $\left(\mathrm{CH}_{2} \mathrm{Cl}_{2}\right)$ in the combustion tube after evaporation and evacuation. If present, the residual solvent would contribute to an older ${ }^{14} \mathrm{C}$ age since it is certainly derived from ${ }^{14} \mathrm{C}$-depleted petroleum products. The second possible source of error would be the loss of some of the isolated compound during evacuation. This would likely result in isotopic fractionation since the lighter $\mathrm{C}$ isotopes would be preferentially removed. Fractionation could also occur during compound isolation if only a portion of the peak is trapped. However, Eglinton et al. (1996) has shown that such fractionation is easily prevented by closely monitoring peak retention times during a trapping sequence.

The extent to which the first two errors may have affected the $\Delta^{14} \mathrm{C}$ analysis can be estimated by comparing compound yields determined from HRGC peak areas versus yields of $\mathrm{CO}_{2}$ generated by combustion of isolated compounds (Fig. 6). In Figure 6 the presence of residual solvent or loss of sample would cause the isolated compound to not plot along the 1:1 line. With the exception of sample M6, most samples tend to lie slightly above the 1:1 line with only a few instances of samples lying below. The ${ }^{14} \mathrm{C}$-age of sample M6, however, is in close agreement with other, structurally similar, isolated compounds which lie closer to the 1:1 line. In addition, sample M6 yielded one of the younger ages determined for compounds isolated from the Arabian Sea (Table 2) indicating that residual solvent was not present. This suggests that the $\mathrm{C}$ yields estimated from either $\mathrm{HRGC}$ or generated $\mathrm{CO}_{2}$ for sample $\mathrm{M} 6$ is in error. The discrepancy between the two estimates can be attributed to two factors. The first is the difficulty associated 
with determining HRGC yields relative to an internal standard ( $n-\mathrm{C}_{32}$ alkane) due to differing response factors for different compound types. The second is that the error in the pressure transducer used to determine $\mathrm{CO}_{2}$ yields, increases with decreasing sample size.

\section{Radiocarbon measurements}

In addition to the 24 isolated hydrocarbons, the total lipid extracts (TLE) from both cores and the saturated hydrocarbon fraction from the Black Sea core were AMS- ${ }^{14} \mathrm{C}$ dated. $\Delta^{14} \mathrm{C}$ values were calculated using an assumed $\delta^{13} \mathrm{C}$ value of $-25 \%_{o_{(\mathrm{PDB})}}$ in cases where the actual $\delta^{13} \mathrm{C}$ value of the isolated compound was not measured (Table 2). Within the error of the AMS- ${ }^{14} \mathrm{C}$ measurements, the $\Delta^{14} \mathrm{C}$ values of the total lipid extracts (Table 2) are indistinguishable from the respective $\Delta^{14} \mathrm{C}_{\mathrm{TOC}}$ determinations for each sediment interval (Table 1). The isolated hydrocarbons, however, exhibited a wide range in $\Delta^{14} \mathrm{C}$ values and corresponding ${ }^{14} \mathrm{C}$ ages (Table 2, Figs. 7 and 8). The individual compounds isolated from the $2-4 \mathrm{~cm}$ interval of Arabian Sea core $6 \mathrm{BC}$ ranged in age from 100 to 10,480 yrs for a C25:3 highly branched isoprenoid and a $n-C_{23}$ alkane, respectively (Fig. 7). In contrast, compounds isolated from the 4-7 cm section of Black Sea core BC4 varied in age from $550 \pm 100$ yrs for a $n$ - $\mathrm{C}_{31}$ alkane to $1380 \pm 170$ yrs for a $n$ $\mathrm{C}_{25}$ alkane (Table 2, Fig. 8).

The span in ages of individual hydrocarbons clearly indicate that several different sources are contributing organic matter to the sediments in both the Arabian and Black Sea. The contribution of marine organic matter to the sediments is evident from the presence of a number of plankton- and bacterially-derived hydrocarbons (Table 2). In the Arabian Sea core, several highly branched isoprenoids (HBI) were isolated as well as two sterols. The HBI are diatom-derived (Volkman et al., 1994) whereas the sterols originate from higher planktonic organisms in general (ten Haven and Rullkotter, 1991). Although both are marine in origin, the ${ }^{14} \mathrm{C}$ ages of the $\mathrm{HBI}$ and sterols are approximately $100-300$ yrs and 600-700 yrs, respectively (Table 2, Fig. 7). One possible explanation for this difference is that the diatoms that produced the HBI may have existed in floating communities in contact with atmospheric $\mathrm{CO}_{2}$. Due to the slow equilibration of $\mathrm{CO}_{2}$ between the atmosphere and ocean, dissolved $\mathrm{CO}_{2}$ has a ${ }^{14} \mathrm{C}$ age approximately 400 yrs 
older than atmospheric $\mathrm{CO}_{2}$ (Broecker and Peng, 1984). Thus, the 'reservoir effect' results in relatively older ${ }^{14} \mathrm{C}$ ages observed for the plankton-derived sterols which integrate all photoautotrophic plankton.

Several hopanoids and $n$-alkanes were also isolated from the Arabian Sea core (Table 2). The hopanoids may have originated from cyanobacteria within the water column, benthic or pelagic heterotrophic bacteria, or from terrestrial plants. The long chain $n$-alkanes, on the other hand, are derived from higher land plants (Eglinton and Hamilton, 1967). The hopanoids range in age from $990-1230$ yrs whereas the $n$-alkanes are $7200-10480$ yrs old. The ${ }^{14} \mathrm{C}$ ages of the hopanoids are similar, yet slightly older than those of the sterols (Table 2). This suggests that the hopanoids are derived from benthic or pelagic heterotrophic bacteria.

The average ${ }^{14} \mathrm{C}$ age of the $n$-alkanes is an order of magnitude greater than both the marine-derived sterols and HBI. Yet, the bulk ${ }^{14} \mathrm{C}_{\text {Toc }}$ age of the $2-4 \mathrm{~cm}$ interval is only $890 \pm 30$ yrs. This suggests that terrigenous material represents a minor source of organic matter to these sediments. A conclusion supported by the $(\mathrm{C} / \mathrm{N})_{\mathrm{a}}$ and $\delta^{13} \mathrm{C}$ values determined for Arabian Sea core 6BC. A closer examination of the HRGC chromatogram of the total saturated hydrocarbons, however, reveals an even distribution of $n$-alkanes at higher molecular weights (Fig. 3b). The distribution is similar to that seen in GC traces of petroleum (e.g. Green River Fm. petroleum, Eglinton et al., 1996). It is possible that petroleum seeps exist in the Arabian Sea sediments which would explain the extremely old ${ }^{14} \mathrm{C}$ ages observed for the long chain $n$-alkanes (Table 2, Fig. 7).

Fewer compounds were isolated from the 4-7 cm section of the Black Sea core, however, they include hydrocarbons from both marine and terrestrial sources (Table 2). Three marine-derived hydrocarbons, $\mathrm{C}_{37}-\mathrm{C}_{39}$ alkenes, were isolated separately by PCGC and then combined to provide sufficient material for AMS- ${ }^{14} \mathrm{C}$ analysis. The $\mathrm{C}_{37}-\mathrm{C}_{39}$ alkenes, which were likely produced by the marine coccolithophore Emiliania huxleyi (Volkman et al., 1980), yielded a ${ }^{14} \mathrm{C}$ age of $960 \pm 100$ yrs (Table 2). In contrast, five, odd C numbered $n$-alkanes $\left(n-\mathrm{C}_{23-31}\right)$, varied in age from $550 \pm 100$ yrs to $1380 \pm 170$ yrs (Table 2). The $n$-alkanes, however, fall into two distinct age groups; a younger group which includes the $n$ - $\mathrm{C}_{29}$ and $n$ - $\mathrm{C}_{31}$ alkanes (550-670 yrs) and an older group including the $n$ - $\mathrm{C}_{23}$ - 
${ }_{27}$ alkanes (1180-1380 yrs) (Fig. 8). The difference in ages suggests that the n-alkanes originate from two distinct sources. The $n-\mathrm{C}_{29}$ and $n$ - $\mathrm{C}_{31}$ alkanes are definitely derived from higher plants (Eglinton and Hamilton, 1967), whereas the $n-\mathrm{C}_{23}, n-\mathrm{C}_{25}$ and possibly the $n-\mathrm{C}_{27}$ alkanes may be bacterially-derived. Assuming that the radiocarbon age of the $\mathrm{C}_{37}-\mathrm{C}_{39}$ alkenes is approximately $400 \mathrm{yrs}$ too old due to the 'reservoir effect', the marine hydrocarbons are of roughly the same age as the terrestrially-derived $n-\mathrm{C}_{29}$ and $n$ - $\mathrm{C}_{31}$ alkanes. The average ${ }^{14} \mathrm{C}$ age of the bulk sediment for the $4-7 \mathrm{~cm}$ section is $871 \mathrm{yrs}$ indicating that the organic matter delivered to this core is primarily marine in origin.

In both the Arabian and Black Sea cores organic matter originating from different sources is being deposited contemporaneously. Individual compounds isolated from these sediments, however, exhibit a broad range in radiocarbon ages. Thus, bulk sediment ${ }^{14} \mathrm{C}$ ages, which have been frequently used to determine sedimentation rates (e.g. Ross and Degens, 1974; Calvert, 1987; Jones and Gagnon, 1994), carbon accumulation rates (Calvert et al., 1987; 1991) and ultimately global C reservoir times (Berner, 1989; Hedges, 1992), represent gross averages which mask the true depositional history of the environment under study. For example, an increase in the relative contribution of either marine or terrestrial organic matter delivered to the sediments could, respectively, increase or decrease bulk TOC-based sedimentation rates. Furthermore, the extremely old radiocarbon ages of the $n$-alkanes isolated from the Arabian Sea indicate that either: 1) there is an ancient $C$ pool present (petroleum seeps), 2) terrestrial organic matter experiences a number of chemical and physical processes prior to deposition, or 3) recycled carbon in being supplied from the continents. The effect each of these possibilities could have on bulk sediment radiocarbon chronologies argues for a new method of determining sedimentation rates. PCGC provides the means to isolate and AMS- ${ }^{14} \mathrm{C}$ date a marine-derived lipid which is not affected by the above difficulties and for which the 'reservoir effect' can be determined. Using the ${ }^{14} \mathrm{C}$ age of the individual lipid to determine $\mathrm{C}$ accumulation rates would undoubtedly lead to a re-evaluation of $\mathrm{C}$ residence times. 


\section{Summary}

Total lipid extracts (TLE) were obtained from the $2-4 \mathrm{~cm}$ horizon of Arabian Sea core $6 \mathrm{BC}$ and from the $4-7 \mathrm{~cm}$ section from Black Sea core $\mathrm{BC} 4$. AMS $-{ }^{14} \mathrm{C}$ measurements were made on the bulk sediment TOC and TLE from both cores as well as the saturated hydrocarbon fraction from the Black Sea core. Twenty-four individual hydrocarbons were isolated from the TLE using Preparative Capillary Gas Chromatography (PCGC) and radiocarbon dated. The ${ }^{14} \mathrm{C}$ ages of the bulk sediment TOC of each core were quite similar to one another and to the respective TLE. The radiocarbon ages of the individual compounds, however, ranged in age from 100 to 10,480 yrs. By isolating known biomarkers it was possible to determine the ${ }^{14} \mathrm{C}$ ages of terrestriäl and marine organic matter sources. From these results it is apparent that most of the isotopic heterogeneity present in recent marine sediments is lost when only the bulk sediment TOC is radiocarbon dated. In future studies the ${ }^{14} \mathrm{C}$ age of individual, marinederived lipids should be determined to obtain more accurate sedimentation rates, $\mathrm{C}$ accumulation rates and ultimately $\mathrm{C}$ reservoir times.

\section{Acknowledgments}

Thanks to Dr. A. McNichol and A. Pearson for help in the NOSAMS Prep-lab, to J. Sachs for collecting the Arabian Sea box core, to Dr. D. Repeta for providing the Black Sea sediment sample and to L. Christman for help with the elemental analyses. This research was funded by NSF grant \# 94-1556800 (T.I. Eglinton). 


\section{References}

Barrick R.C. and Hedges J.I. (1981) Hydrocarbon geochemistry of the Puget Sound region - II. Sedimentary diterpenoid, steroid, and triterpenoid hydrocarbons. Geochim. Cosmochim. Acta, 45, 381-392.

Benoit G.J., Turekian K.K. and Bennunger L.K. (1979) Radiocarbon dating of a core from Long Island Sound. Est. Coastal Mar. Sci. 9, 171-180.

Berner R.A. (1989) Biogeochemical cycles of carbon and sulfur and their effect on atmospheric oxygen over Phanerzoic time. Palaeogeo., Paleoclim., Palaeoclolgy, 75, 97-122.

Calvert S.E. (1987) Oceanographic controls on the accumulation of organic matter in marine sediments. In: Marine petroleum source rocks (eds J. Brooks and A.J. Fleet) Geol. Soc. Spec. Publ. 26, 137-151.

Calvert S.E. and Pedersen T.F. (1992) Organic carbon accumulation and preservation in marine sediments: How important is anoxia? In: Productivity, accumulation and preservation of organic matter in recent and ancient sediments (eds. Whelan J.K. and Farrington J.W.) Columbia University Press.

Calvert S.E., Vogel J.S. and Southon J.R. (1987) Carbon accumulation rates and the origin of the Holocene sapropel in the Black Sea. Geology, 15, 918-921.

Calvert S.E., Karlin R.E., Toolin L.J., Donahue D.J., Southon J.R. and Vogel J.S. (1991) Low organic carbon accumulation rates in Black Sea sediments. Nature, 350, 692695.

Cowie G.L. and Hedges J.I. (1992) The role of anoxia in organic matter preservation in coastal sediments: relative stabilities of the major biochemicals under oxic and anoxic depositional conditions. Org. Geochem. 19, 229-234.

de Leeuw J.W. and Largeau C. (1993) A review of macromolecular organic compounds that comprise living organisms and their role in kerogen, coal, and petroleum fromation. In: Organic geochemistry (M.H. Engel and S.A. Macko eds.) Plenum Press, New York, pp. 23-72.

Deines P. (1980) The isotopic composition of reduced organic carbon. In: Handbook of environmental isotope geochemistry. (eds P. Fritz and J.C. Fontes) Elsevier, pp.329-406.

Durand B. (1980) Kerogen - insoluble organic matter from sedimentary rocks. Editions Technip, Paris, 599 pp.

Eglinton T.I., Aluwihare L.I., Bauer J., Druffel E.R.M. and McNichol A.P. (1996) Gas chromatographic isolation of individual compounds from complex matrices for radiocarbon dating. Anal. Chem., in press.

Freeman K.H. and Wakeham S.G. (1992) Variations in the distribution and isotopic compositions of alkenones in Black Sea particles and sediments. Org. Geochem. 19, 277-285. 
Fry B., Brand W., Mersch F.J., Tholke K. and Garrit R. (1992a) Anal. Chem. 64, 288.

Fry B., Jannasch H.W., Molyneaux S.J., Wirsen C.O., Muramoto J.A. and King S. (1992b) Stable isotope studies of carbon, nitrogen and sulfur cycles in the Black Sea. Deep-Sea Res. 38 (Suppl.), S1003-S1019.

Hatcher P.G. and Spiker E.C. (1988) Selective degradation of plant biomolecules. In: Humic substances and their role in the environment (Frimmel F.H. and Christman R.F. eds.) Wiley, New York, pp. 59-74.

Hedges J.I. (1992) Global biogeochemical cycles: progress and problems. Marine Chem. 39, 67-93.

Jones G.A. and Gagnon A.R. (1994) Radiocarbon chronology of Black Sea sediments. Deep-Sea Research, 41, 531-557.

Karl D.M. and Knauer G.A. (1991) Microbial production and particle flux in the upper $350 \mathrm{~m}$ of the Black Sea. Deep Sea Res. 38 (Suppl.), S921-S942.

Kroopnick P.M. (1985) The distribution of ${ }^{13} \mathrm{C}$ in the world oceans. Deep-Sea Res. 32, 57-84.

Lee C. (1992) Controls on organic carbon preservation: the use of stratified water bodies to compare intrinsic rates of decomposition in oxic and anoxic systems. Geochim. Cosmochim. Acta, 56, 3323-3335.

McNichol A.P., Gagnon A.R., Jones G.A. and Osborne E.A. (1992) Radiocarbon, 34, 321.

Paropkari A.L., Babu C.P. and Mascarenhas A. (1992) A critical evaluation of depositional parameters controlling the variability of organic carbon in Arabian Sea sediments. Marine Geol. 107, 213-226.

Pedersen T.F. and Calvert S.E. (1990) Bull. Am. Ass. Petrol. Geol. 74, 454-466.

Pedersen T.F., Shimmield G.B. and Price N.B. (1992) Lack of enhanced preservation of organic matter in sediments under the oxygen minimum on the Oman Margin. Geochim. Cosmochim. Acta, 56, 545-551.

Ross D.A. and Degens E.T. (1974) Recent sediment of the Black Sea. In: The Black Seageology, chemistry, and biology. (E.T. Degens and D.A. Ross, eds). AAPG Memoir, 20, 183-199, Tulsa, Ok.

Rowland S.J. and Maxwell J.R. (1984) Reworked triterpenoid and steroid hydrocarbons in a recent sediment. Geochim. Cosmochim. Acta, 48, 617-624.

Sackett W.M. and Thompson R.R. (1963) Isotopic organic carbon compostion of recent continental derived clastic sediments of eastern gulf coast, Gulf of Mexico. AAPG Bull. 47, 525.

Sackett W.M., Poag C.W. and Eadie B.J. (1974) Kerogen recycling in the Ross Sea, Antarctica. Science, 185, 1045-1046. 
Simoneit B.R.T. (1977) The Black Sea, a sink for terrigenous lipids. Deep-Sea Res. 24, 813-830.

Sun M-Y., Lee C. and Aller R.C. (1993) Laboratory studies of oxic and anoxic degradation of chlorophyll-a in Long Island sediments. Geochim. Cosmochim. Acta, 57, 147-157.

Tegelaar E.W., de Leeuw J.W., Derenne S. and Largeau C. (1989) A reapraisal of kerogen formation. Geochim. Cosmochim. Acta, 53, 3103-3106.

ten Haven H.L. and Rullkotter J. (1991) Preliminary lipid analysis of sediments recovered during Leg 117. In: Proceedings of the Ocean Drilling Program, Scientific Results, Vol. 117.

Tissot B.P. and Welte D.H. (1984) Petroleum Formation and Occurrance. SpringerVerlag.

Volkman J.K., Eglinton G., Corner E.D.S. and Forsberg T.E.V. (1980) Long-chain alkenes and alkenones in the marine coccolithophorid Emiliania huxleyi. Phytochemistry, 19, 2619-2622.

Volkman J.K., Barrett S.M. and Dunstan G.A. (1994) $\mathrm{C}_{25}$ and $\mathrm{C}_{30}$ highly branched isoprenoid alkenes in laboratory cultures of two marine diatoms. Org. Geochem. 21, 407-413. 
Table 1. Elemental and isotopic composition of bulk sediment samples.

\begin{tabular}{|c|c|c|c|c|c|c|c|c|c|c|}
\hline $\begin{array}{l}\text { Sample } \\
\text { Location }\end{array}$ & $\begin{array}{l}\text { Depth } \\
(\mathrm{cm})\end{array}$ & $\begin{array}{c}\text { TOC } \\
\text { (Wt. \%) }\end{array}$ & $\begin{array}{c}\mathrm{TN} \\
\text { (Wt. \%) }\end{array}$ & $(\mathrm{C} / \mathrm{N})_{\mathrm{a}}$ & $\begin{array}{c}\delta^{13} \mathrm{C}_{\mathrm{TOC}} \\
(\% 0)^{1}\end{array}$ & $\begin{array}{c}\delta^{13} \mathrm{C}_{\mathrm{TOC}} \\
(\% 0)^{2}\end{array}$ & $\begin{array}{c}\Delta^{14} \mathrm{C}_{\text {тос }} \\
(\% 0)\end{array}$ & $\begin{array}{c}\Delta^{14} \mathrm{C}_{\mathrm{TOC}} \\
\text { error }\end{array}$ & $\begin{array}{c}{ }^{14} \mathrm{C} \text { Age } \\
(\mathrm{yrs})^{3}\end{array}$ & $\begin{array}{c}{ }^{14} \mathrm{C} \text { Age } \\
\text { error }\end{array}$ \\
\hline \multirow[t]{5}{*}{ Arabian Sea 6BC } & $0-2$ & 6.40 & 0.64 & 11.7 & -20.6 & -21.7 & -84.0 & \pm 3.1 & 665 & \pm 25 \\
\hline & $2-4$ & 6.66 & 0.74 & 10.5 & $=20.6$ & -21.7 & -109 & \pm 3.3 & 890 & \pm 30 \\
\hline & $4-6$ & 6.48 & 0.73 & 10.4 & -20.5 & -21.5 & -108 & \pm 3.1 & 880 & \pm 25 \\
\hline & $6-8$ & 6.58 & 0.72 & 10.7 & -20.4 & -21.4 & -118 & \pm 2.8 & 965 & \pm 25 \\
\hline & $8-10$ & 4.20 & 0.57 & 8.60 & -20.4 & -21.4 & -136 & \pm 2.5 & 1130 & \pm 25 \\
\hline \multirow[t]{6}{*}{ Black Sea BC4 } & $4.0-4.5$ & 4.64 & 0.41 & 13.2 & -24.2 & n.d. & -103 & \pm 2.8 & 830 & \pm 25 \\
\hline & $4.5-5.0$ & 4.68 & 0.39 & 14.0 & -23.6 & -25.0 & -114 & \pm 3.0 & 930 & \pm 25 \\
\hline & $5.0-5.5$ & 3.94 & 0.32 & 14.4 & -23.6 & -25.2 & -115 & \pm 2.9 & 940 & \pm 25 \\
\hline & $5.5-6.0$ & 5.95 & 0.47 & 14.8 & -24.0 & -25.1 & -91.9 & \pm 2.6 & 735 & \pm 25 \\
\hline & $6.0-6.5$ & 6.24 & 0.51 & 14.3 & -24.0 & -25.2 & -106 & \pm 3.2 & 865 & \pm 30 \\
\hline & $6.5-7.0$ & 7.66 & 0.61 & 14.7 & -24.3 & n.d. & -113 & \pm 2.8 & 925 & \pm 25 \\
\hline
\end{tabular}

n.d.: Not determined.

$(\mathrm{C} / \mathrm{N})_{\mathrm{a}}$ : Atomic ratio of carbon to nitrogen.

1: Analysis conducted at MBL.

2: Analysis conducted at NOSAMS.

3: Radiocarbon age reported using Libby half-life of 5568 years, and according to the convention of Stuiver and Polach (1977) and Stuiver (1980). 
Table 2. Isotopic composition of isolated compounds.

\begin{tabular}{|c|c|c|c|c|c|c|c|c|c|}
\hline $\begin{array}{l}\text { Compound/ } \\
\text { Fraction }\end{array}$ & $\begin{array}{l}\text { PCGC } \\
\text { I.D. }\end{array}$ & $\begin{array}{c}\text { AMS } \\
\text { Facility }\end{array}$ & $\begin{array}{c}\text { GC Yield } \\
(\mu \mathrm{g} \mathrm{C})^{1}\end{array}$ & $\begin{array}{c}\mathrm{CO}_{2} \text { Yield } \\
(\mu \mathrm{g} \mathrm{C})\end{array}$ & $\begin{array}{l}\delta^{13} \mathrm{C} \\
(\% o)\end{array}$ & $\begin{array}{l}\Delta^{14} \mathrm{C} \\
(\% o)\end{array}$ & $\begin{array}{l}\Delta^{14} \mathrm{C} \\
\text { error }^{2}\end{array}$ & $\begin{array}{l}{ }^{14} \mathrm{C} \text { Age } \\
(\mathrm{yrs})^{3}\end{array}$ & $\begin{array}{l}{ }^{14} \mathrm{C} \text { Age } \\
\text { error }\end{array}$ \\
\hline \multicolumn{10}{|c|}{ Arabian Sea core $6 B C, 2-4 \mathrm{~cm}$} \\
\hline TLE & - & LLNL & n.d. & 770 & n.d. & -99.9 & \pm 6.3 & 800 & \pm 60 \\
\hline $\mathrm{C} 25: 4 \mathrm{HBI}$ & N1 & LLNL & 47 & 35 & n.d. & -38.2 & \pm 15.0 & 270 & \pm 130 \\
\hline C25:3 HBI & M1 & NOSAMS & 103 & 118 & -19.97 & -17.8 & & 100 & \\
\hline C25:2 HBI & M2 & NOSAMS & 125 & 123 & -20.16 & -25.5 & & 170 & \\
\hline C30 sterene & N4 & LLNL & 176 & 149 & n.d. & -74.6 & \pm 7.1 & 580 & \pm 70 \\
\hline C30 sterene & N3 & LLNL & 83 & 77 & n.d. & -84.7 & \pm 8.2 & 670 & \pm 80 \\
\hline C27:1 sterene & M3 & NOSAMS & 65 & 124 & -24.90 & -89.0 & & 710 & \\
\hline C30 hopene & N5 & LLNL & 6 & 60 & n.d. & -128.5 & \pm 8.7 & 1060 & \pm 90 \\
\hline C30 hopene & N6 & LLNL & 39 & 49 & n.d. & -146.6 & \pm 9.4 & 1230 & \pm 90 \\
\hline C27:3 hopene & M4 & NOSAMS & 48 & 94 & n.d. & -134.2 & & 1120 & \\
\hline Unk. alkene & M5 & NOSAMS & 12 & 86 & n.d. & -96.4 & & 780 & \\
\hline C30:1 hopene & M6 & NOSAMS & 6 & 156 & -23.48 & -120.5 & & 990 & \\
\hline$n$ - $\mathrm{C}_{23}$ alkane & L1 & NOSAMS & 13 & 56 & n.d. & -730.2 & & 10480 & \\
\hline$n-\mathrm{C}_{27}$ alkane & L2 & NOSAMS & 80 & 105 & -26.90 & -678.0 & & 9070 & \\
\hline C27 hopane & L3 & NOSAMS & 114 & 131 & -25.76 & -594.0 & & 7200 & \\
\hline$n-C_{29}$ alkane & L4 & NOSAMS & 131 & 147 & -25.87 & -596.1 & & 7250 & \\
\hline Fernene & L6 & NOSAMS & 97 & 134 & -24.24 & -603.9 & & 7400 & \\
\hline \multicolumn{10}{|c|}{ Black Sea core BC4, 4-7 cm } \\
\hline TLE (i) & - & LLNL & n.d. & 167 & n.d. & -110.6 & \pm 7.2 & 900 & \pm 70 \\
\hline TLE (ii) & - & LLNL & n.d. & 207 & n.d. & -115.9 & \pm 5.9 & 950 & \pm 60 \\
\hline Saturated HC & - & LLNL & n.d. & 37 & n.d. & -154.8 & \pm 15.2 & 1310 & \pm 150 \\
\hline$n-C_{23}$ alkane & O1 & LLNL & 48 & 26 & n.d. & -158.0 & \pm 12.7 & 1340 & \pm 130 \\
\hline$n-C_{25}$ alkane & $\mathrm{O} 2$ & LLNL & 18 & 16 & n.d. & -162.3 & \pm 17.1 & 1380 & \pm 170 \\
\hline$n-\mathrm{C}_{27}$ alkane & $\mathrm{O} 4$ & LLNL & 36 & 47 & n.d. & -141.2 & \pm 9.4 & 1180 & \pm 90 \\
\hline$n-\mathrm{C}_{29}$ alkane & O5 & LLNL & 29 & 60 & n.d. & -84.5 & \pm 9.3 & 670 & \pm 90 \\
\hline$n-C_{31}$ alkane & O6 & LLNL & 61 & 70 & n.d. & -70.7 & \pm 10.6 & 550 & \pm 100 \\
\hline $\mathrm{C}_{37-39}$ alkenes & P4-P6 & LLNL & 3 & 70 & n.d. & -116.9 & \pm 10.0 & 960 & \pm 100 \\
\hline
\end{tabular}

n.d.: Not determined.

1: Isolated compound yield determined from HRGC.

2. The error determinations for several $\triangle{ }^{14} \mathrm{C}$ and ${ }^{14} \mathrm{C}$ Age values were not completed in time to be included. Once completed they will be available from the author.

3: Radiocarbon age reported using Libby half-life of 5568 years, and according to the convention of Stuiver and Polach (1977) and Stuiver (1980). 

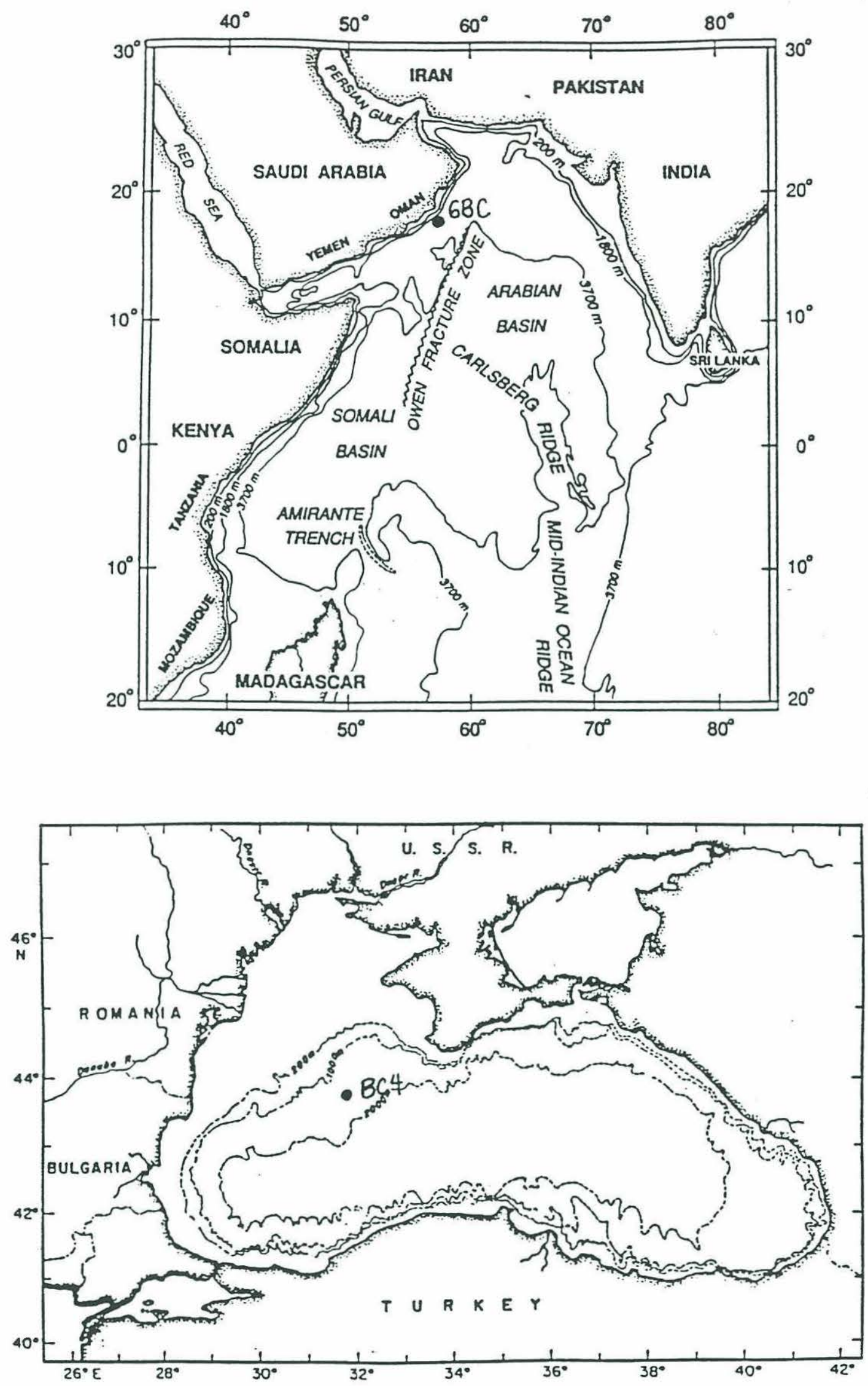

Figure 1. Location of (a) box core 6BC in the Arabian Sea and (b) box core BC4 in the Black Sea. 


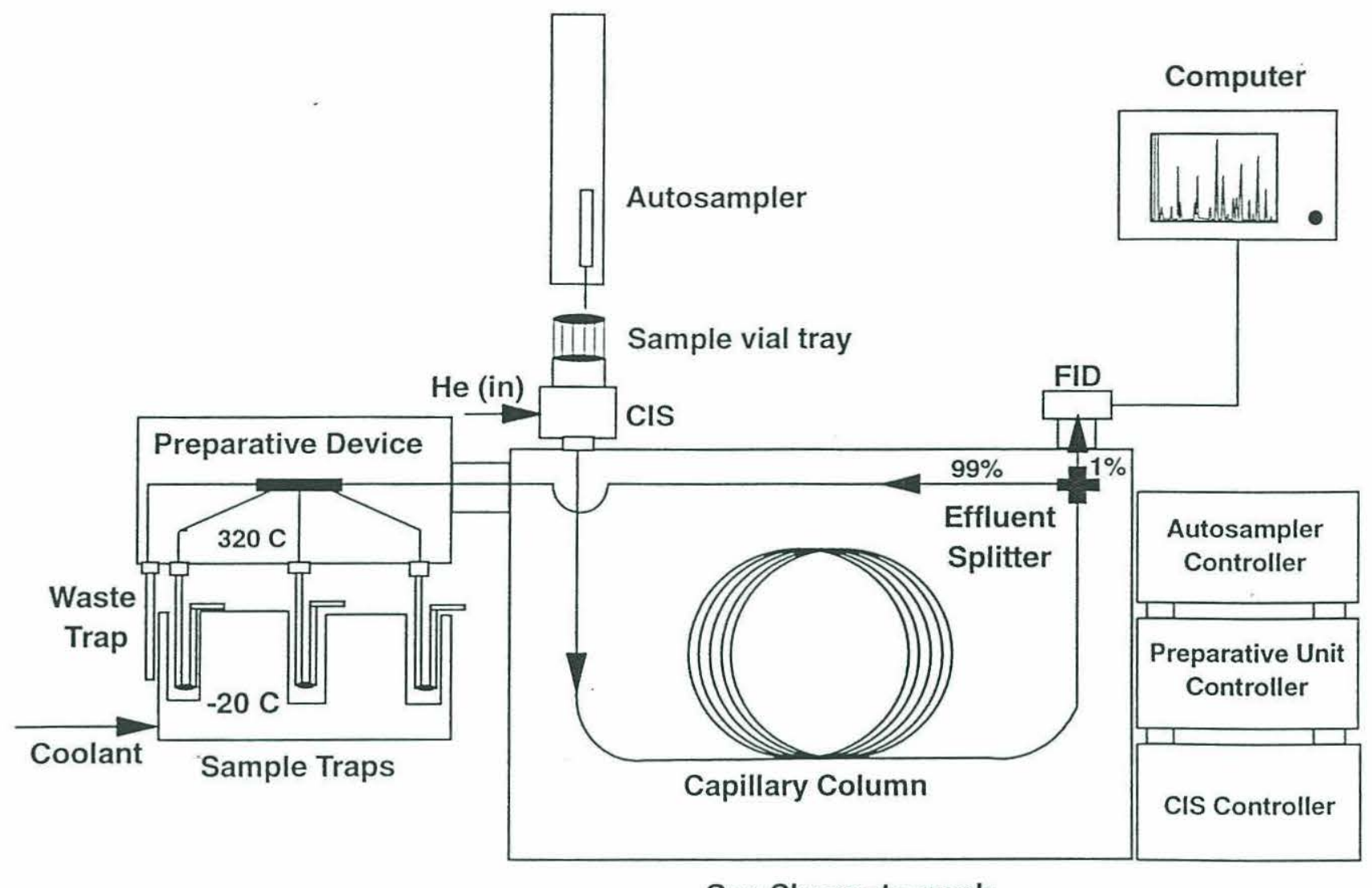

Gas Chromatograph

Figure 2. Diagram of the PCGC instrument. 

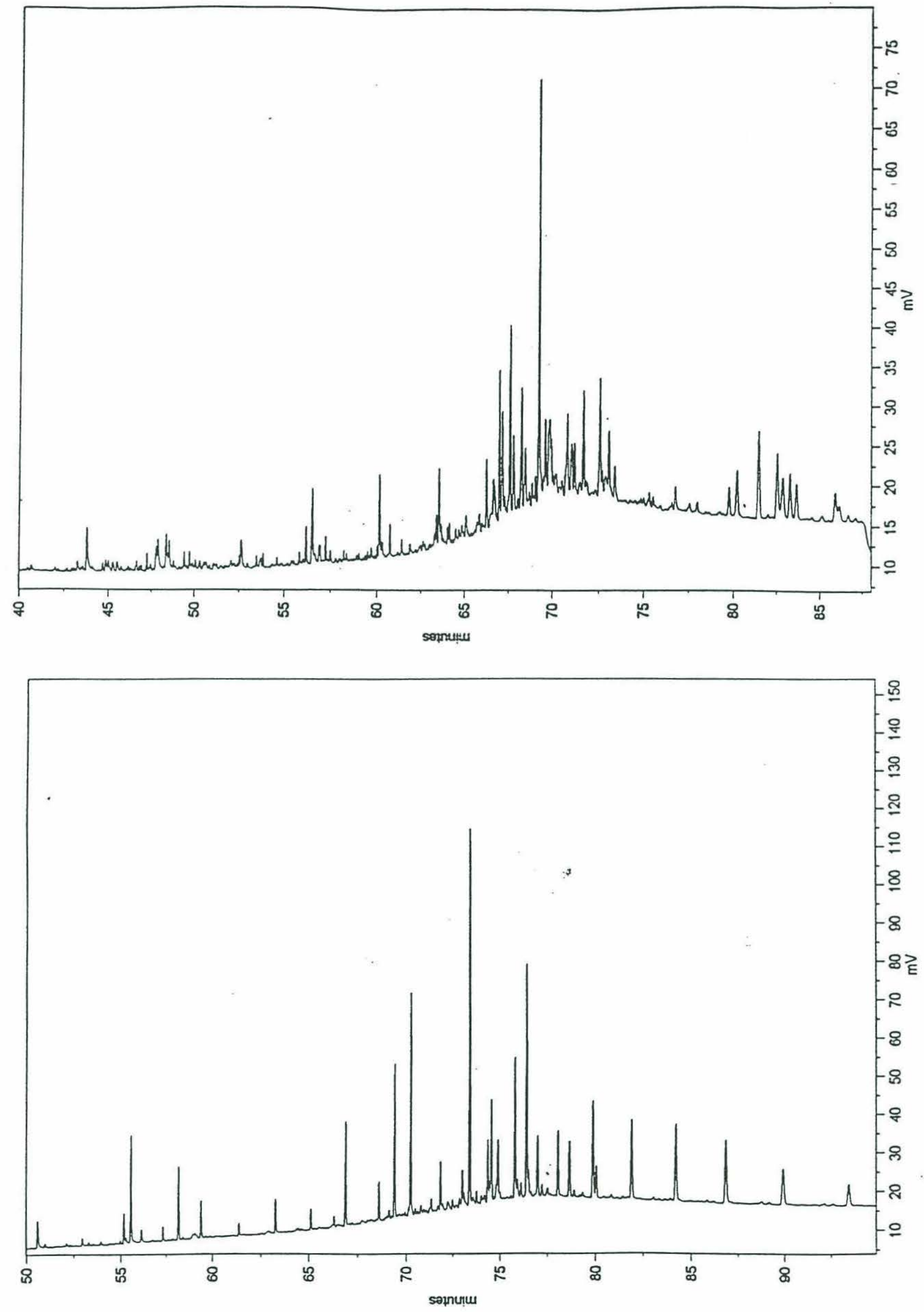

Figure 3. HRGC traces of (a) the TLE and (b) saturated hydrocarbon fraction from Arabian Sea core 6BC. 


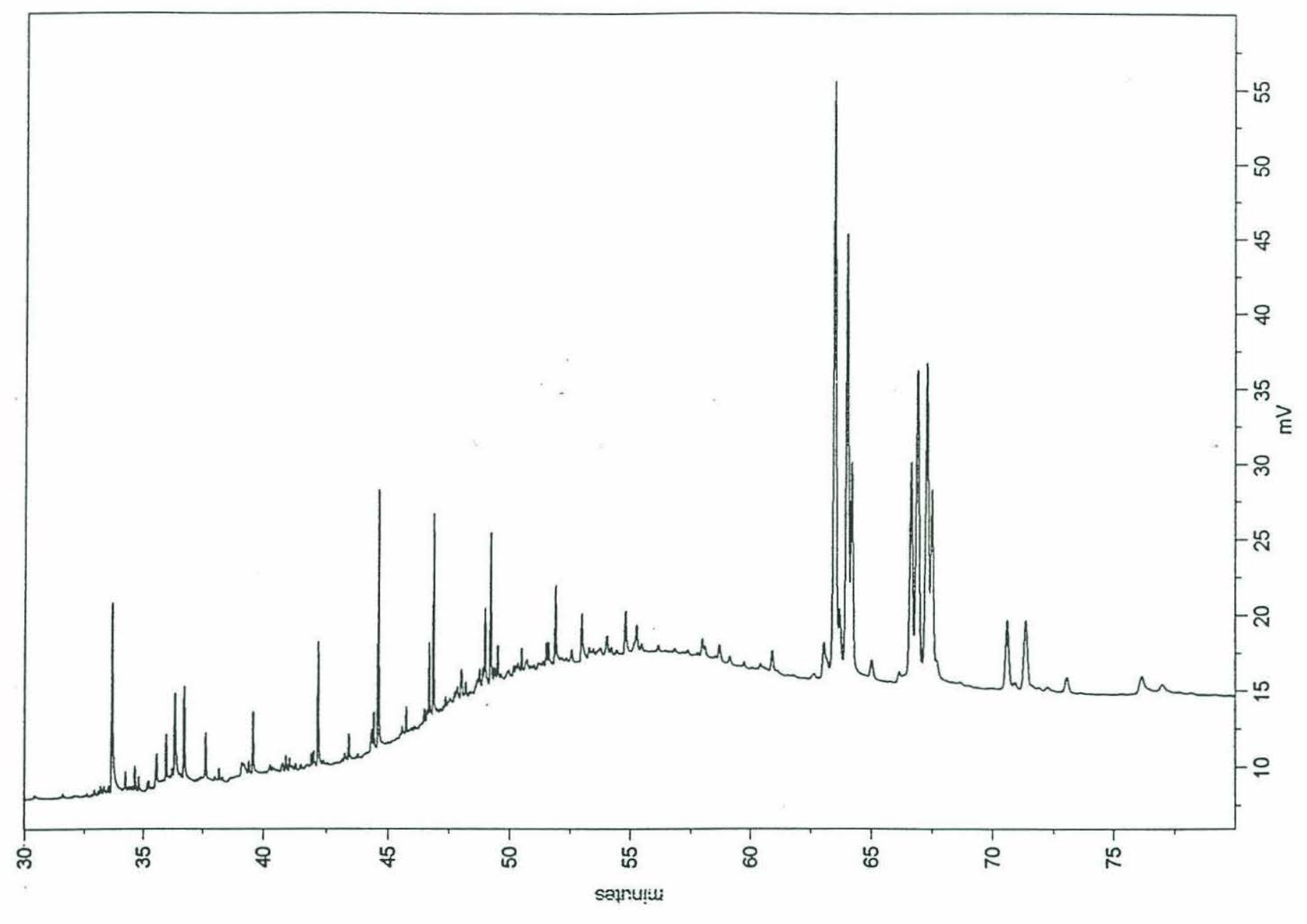

Figure 4. HRGC trace of the TLE from Black Sea core BC4. 


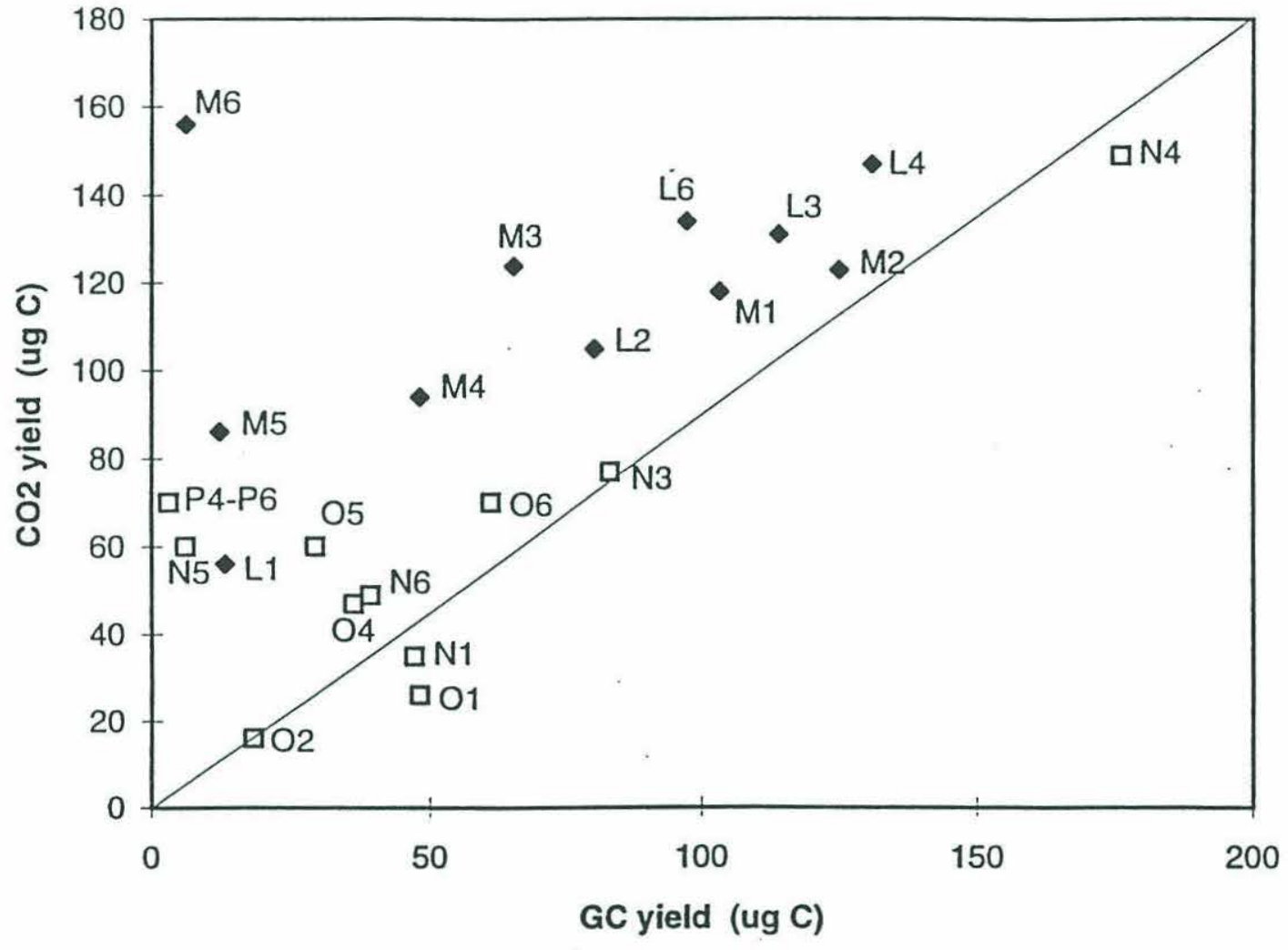

Figure 6. Plot of compound yields (as $\mu \mathrm{g} \mathrm{C}$ ) from PCGC estimated by HRGC (peak area) versus combustion (manometric measurement of $\mathrm{CO}_{2}$ ). Closed diamonds represent samples analyzed at NOSAMS; open squares represent samples analyzed at LLNL. The solid line represents the 1:1 curve. The PCGC I.D. is shown next to each symbol and listed in Table 2. 


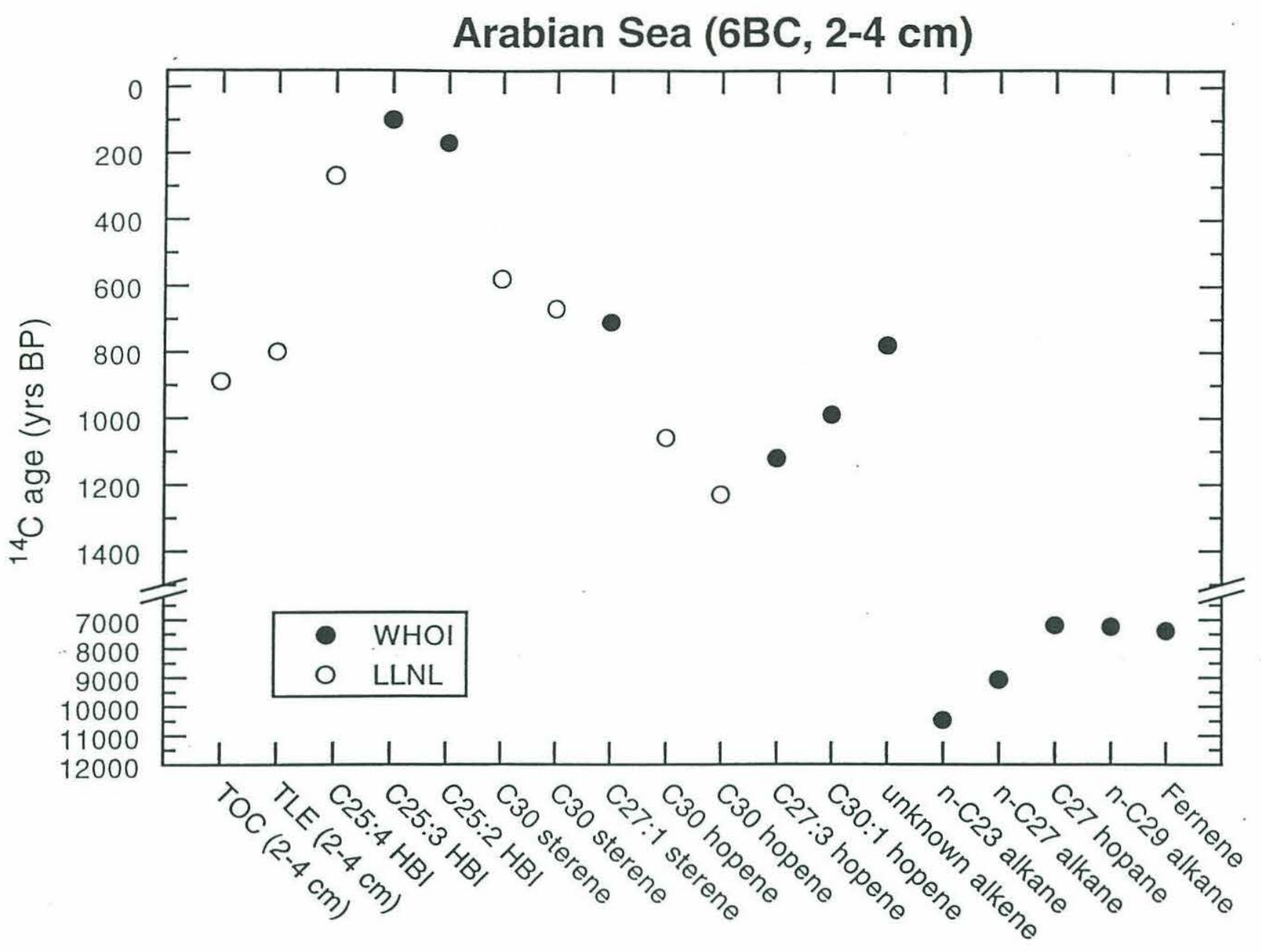

Figure 7. Plot of ${ }^{14} \mathrm{C}$ ages for all compounds isolated from Arabian Sea core $6 \mathrm{BC}$. Open circles represent samples analyzed at LLNL; closed circles represent samples analyzed at NOSAMS. 


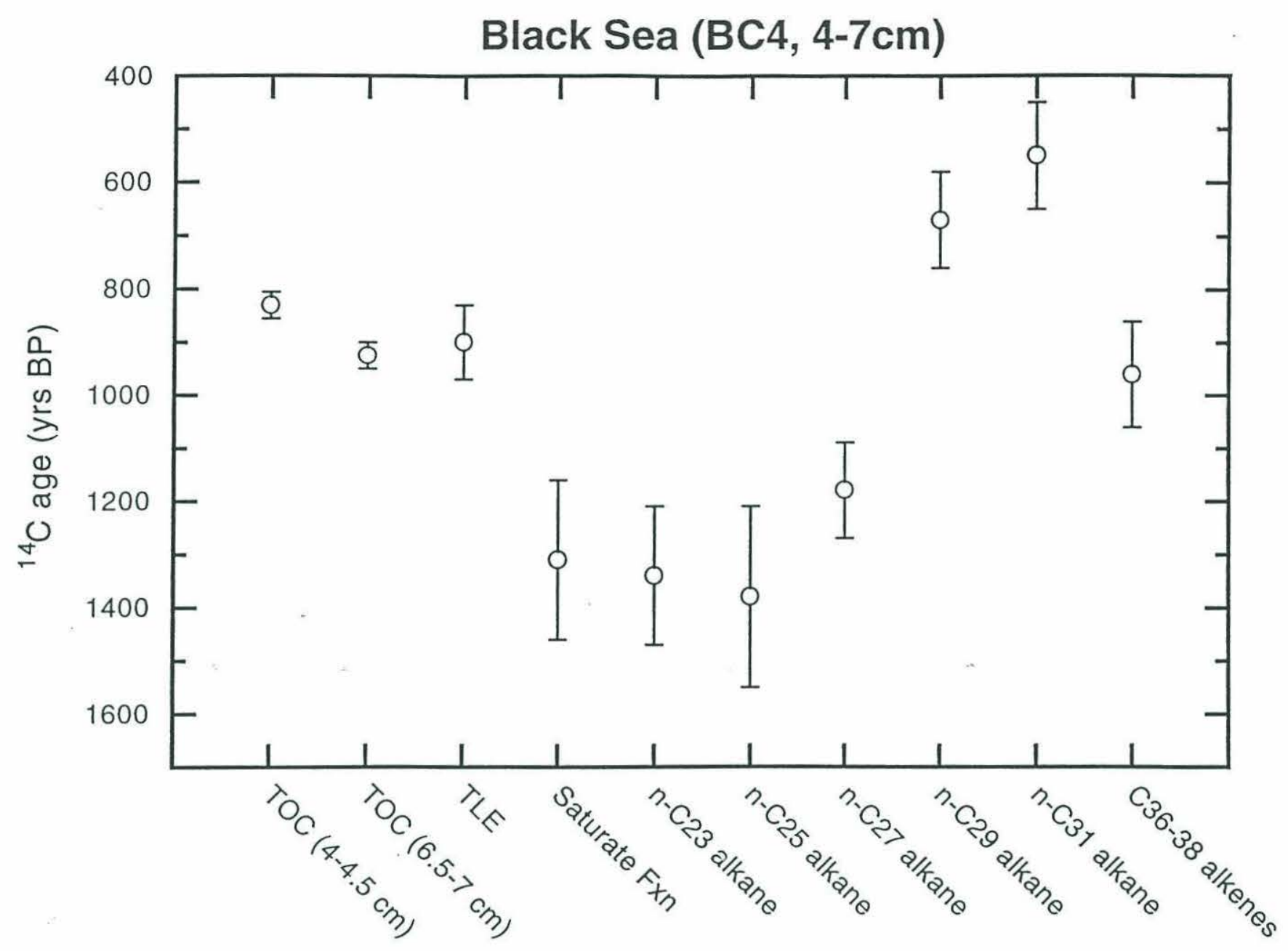

Figure 8. Plot of ${ }^{14} \mathrm{C}$ ages for all compounds isolated from Black Sea core BC4. Open circles represent samples analyzed at LLNL; closed circles represent samples analyzed at NOSAMS. 